\title{
Shared Spatial Regulating in Sharing-Economy Districts
}

\author{
Michael N. Widener*
}

\begin{abstract}
Digital technology, coupled with present economic conditions and the interest of younger Americans in sustainability, has enabled a climate favorable to collaborative consumption. More individuals will be engaged over time in the on-demand "sharing economy" because underemployment of the middle class, and a majority of all non- or under-skilled workers, is a chronic condition eluding ready solution. This new resources "lending" and social networking culture assures ongoing introductions of sharing producers and consumers to each other and into residential neighborhoods. The result of such engagement will include increased traffic trips, overtaxed curbside parking spaces, additional ambient noise and enhanced stress upon electric and other utility grids tapped by sharing enterprises. Since these neighborhood burdens are not addressed in the form of sales taxes or license fees directly returned to host enclaves, many of these burdens are borne largely by dwellers. Local persons not participating in the sharing economy expect their daily routines to continue without interference from unfamiliar persons, noises and odors, or the disadvantages of increased traffic and reduced curbside parking.

Communities now are challenged to regulate sharing uses in this new economic order while accommodating opportunities for such enterprises to generate revenue and taxes. In one regard, accommodation invites struggles between established neighborhood dwellers and later-arriving sharing producers operating outside zoning regulations. Even so, outright prohibiting of entrepreneurial models in residential zoning districts counters local governments' efforts to remake the economic and social landscapes of urban communities, especially those mired precariously in circumstances of joblessness, crime and other types of disorder. Many sharing economy voices argue that today's good land use decisions mandate subordinating neighborhood inconvenience to this new business climate's benefit to the larger community, the "greater good." This is the first paper in American academic legal literature addressing how communities might accept this challenge to accommodate the new economy, productively modernizing governmental spatial regulatory prerogatives through incorporating crucial citizen inputs at this land use
\end{abstract}


crossroads.

I. INTRODUCTION 112

II. THE PARAmeters OF THE SHARED ECONOMY MOVEMENT, AND ITS SALUTARY FEATURES

A. Players in the Sharing Economy 119

B. Principles of the Sharing Economy Movement ...... 122 III.WHY THE SHARING ECONOMY REQUIRES LAND USE REGULATION 125

IV.HARNESSING SHARING ECONOMY LAND USE REGULATION: PUBLIC AND PRIVATE INPUTS. 133

A. Public Regulation of Sharing Economy Land Use Dimensions. ................................................... 133

B. Private Regulation of Sharing Economy Land Use Dimensions .................................................. 140

1. Grass Roots Citizens' Regulation ..................... 143

2. Newer Models of Citizen-Driven Organizations for Land Use Oversight 149

3. A Proposal for Inclusiveness of Stakeholders in Sharing Economy Districts ............................ 153

C. Determining Sharing Enterprise Neighborhood Compatibility Standards .................................. 157

V. "Absolute" LAND USE DEREgulation OF THE SHARING ECONOMY …....................................................... 161

VI. The Future OF PRIVATE REgulation OF SHARING

ENTERPRISES ................................................... 167

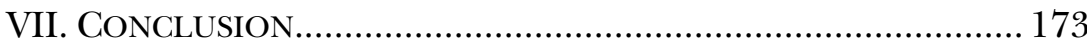

APPENDIX: LEXICON ...................................................... 185

\section{INTRODUCTION}

Does your neighbor rent out his or her apartment or condo shortterm through Airbnb, Inc. without violating the local zoning code? ${ }^{1}$ Why not rent out space in your single-family home-is that permitted in your neighborhood? ${ }^{2}$ Classic (Euclidean) zoning codes

*Adjunct Professor, Arizona Summit Law School; Zoning Adjustment Hearing Officer, City of Phoenix; Of Counsel, Bonnett, Fairbourn, Friedman \& Balint, P.C. This is for Peggy, with gratitude for sharing our lives and love. Unfamiliar terms contained in this paper likely are defined in the Lexicon appearing at the end.

See Stephen R. Miller, First Principles for Regulating the Sharing Economy, 52 HARV. J. ON LEGIS. (forthcoming 2015). Professor Miller's fine treatment highlights positive and negative externalities of the transient lodging Sharing Enterprise niche.

2 This has occurred for decades in some communities, in violation of many 
purposefully draw sharp distinctions between land uses, permitting some types in certain districts ${ }^{3}$ while discriminating against remaining uses either by outright prohibition or imposing expensive or inconvenient constraints. Depending on the community, such codes may or may not accommodate flexibility of residentially-zoned activity. ${ }^{4}$ The demographics of cities are changing, and a population increase in young, single workers already has impacted housing stock, illustrated by evolution of the micro-dwelling unit. ${ }^{5}$ While this "bolt-on" housing accommodation type initially may have been intended to move elderly family members back with relatives, ${ }^{6}$ these units become fertile sources of steady income when let to younger professional workers or short term travelers. ${ }^{7}$ Yet some communities lament occupancy of these units by unknown persons. ${ }^{8}$

zoning regulations, in the form of home rentals in environments of major events such as professional golf tournaments or the Super Bowl. See, e.g., Laurie Merrill, Super Bowl Home Rental Prices Soar in Phoenix Area, The Ariz. Republic (Aug. 11, 2014 5:45 PM), http:/ /www.azcentral.com/story/money/business/2014/08/11/super-bowl-homerental-prices-soar-in-phoenix-area/13896283/; Meg Mirshak, Augusta Homeowners Earn Big on Masters Week Rentals, The Augusta Chronicle (Feb. 25, 2012), http://chronicle.augusta.com/news/business/local-business/2012-02-25/augustahomeowners-earn-big-masters-week-rentals.

3 For instance, some classic "sharing economy" activities of the charitable sort, such as food and clothing banks, are specified permitted uses in some districts. Also, "sharing" uses and activities, such as boarding houses, group homes and yard sales, are addressed by specific zoning ordinance provisions, as they have been for decades, often as the subject of conditional use permits. See, e.g., Conditional Use Permit (CUP), CiTY OF TACOMA, http://www.govme.com/Common/Doc/DisplayDoc.aspx? category=TipSheet\&id=P-111 (last visited Feb. 28, 2015).

For the most part, segregation of uses continues to dominate American zoning schemes, even in New Urbanist communities where modest-scale commercial uses are "zoned out." See Miller, supra note 1, at 17 n.70.

${ }^{5}$ See Vicki Been, Benjamin Gross \& John Infranca, Responding to Changing Households: Regulatory Challenges for Micro-Units and Accessory Dwelling Units, NYU FURMAN Center For REAL Estate AND Urban Policy 8-10 (Jan. 2014), http:/ / furmancenter.org/files/NYUFurmanCenter_RespondingtoChangingHouseh olds_2014_1.pdf.

See John Infranca, Housing Changing Households: Regulatory Challenges for MicroUnits and Accessory Dwelling Units, 25 STAN. L. \& POL'Y REV. 53, 64-65 (2014), available at http://journals.law.stanford.edu/sites/default/files/stanford-law-policyreview/print/2014/01/infranca_25_stan._l._poly_rev_53.pdf; The Other Boomerang Generation, WALL ST. J. (Nov. 5, 2014, 11:41 AM), http://www.wsj.com/video/theother-boomerang-generation/DC079F2C-72D9-441F-9218-

7E01121BAC58.html?mod=wsj_email_newsletter.

7 See Infranca, supra note 6 , at 61 (noting that micro-units may not provide affordable housing but may exacerbate high community rental rates).

8 See id. at 62-63 (discussing how opponents state fears of flooding neighborhoods with itinerant or "sketchy" dwellers). 
Another example of a sharing economy model $^{9}$ is the "pop-up family dinner," where strangers share a table and prepared food..$^{10}$ Are local land use regulations flexible enough to contemplate meal sharing (outside of social, gratuitous settings where the diners know their hosts)? What about bicycle,${ }^{11}$ motorcycle or even $c a{ }^{12}$ or parking-

9 To skirt utter definitional confusion, I acknowledge here the work of Lawrence Lessig, who perhaps would view this illustration as exemplifying what he calls the "hybrid economy," existing when "a commercial entity ... aims to leverage value from a sharing economy, or ... a sharing economy that builds a commercial entity to better support its sharing aims." Either way, the hybrid links two simpler, or purer, economies and produces something from the link. See LAWREnCE Lessig, REMIX: MAKing ART AND Commerce Thrive IN THE Hybrid Economy, 177-78 (2008). Lessig's definition of a sharing economy, in purest form, is one not involving an actor's engagement in generating revenue. See id. at 118-19, 152-54. Of course, most of today's references to "the sharing economy" in the tech world conflate informationsharing and money-making, so long as revenue is spread among the "vendors," with business-model entrepreneurs reaping a percentage of the sums paid by consumers for the goods and services offered by sharing producers.

10 See Amy Lombard, Five Noteworthy Startups from TechCrunch Disrupt NY, TIME INNOVATION BLOG (May 2, 2013), http://techland.time.com/2013/05/02/fivenoteworthy-startups-from-techcrunch-disrupt-ny/slide/eatwith-airbnb-for-therestaurant-industry/ (describing EatWith, a sharing cuisine site); competition in this space already includes With Locals (www.withlocals.com) and KitchHike (https://en.kitchhike.com/). There is a non-tech element to this and other types of sharing entrepreneurship models that can be overlooked due to "sub-radar" scale and skirting of local regulatory requirements. See Scott Beyer, The Motor City's Regulators Are Hitting the Brakes on Regrowth, WALL ST. J., Dec. 13, 2014, at A13, available at http://www.wsj.com/articles/scott-beyer-the-motor-citys-regulators-are-hitting-the-

brakes-on-regrowth-1418426736. It is short-sighted to welcome some forms of Sharing Enterprises that are better-financed while repressing "self-help" activities that mean economic survival for their actors, so long as certain minimum health and safety standards are observed by the sharing producers; the trick is finding the sensible balance affording participants public safety (e.g., avoidance of food-borne illness), entrepreneurial opportunity and community building settings. See Sarah Schindler, Regulating the Underground: Secret Supper Clubs, Pop-Up Restaurants, and the Role of Law, 82 U. Chi. L. Rev. Dialogue 16, 27-29, 35 (2015), available at https:// lawreview.uchicago.edu/sites/lawreview.uchicago.edu/files/uploads/Schindler_Dial ogue.pdf.

${ }_{11}$ See Jeremy Rifkin, Op-Ed., The Rise of the Sharing Economy, L.A. TImEs (Apr. 6, 2014), http://articles.latimes.com/2014/apr/06/opinion/la-oe-rifkin-airbnb20140406 ("[A]n increasing number of young people are deciding they don't need to own bikes; they are perfectly happy to have access to shared bikes, and pay only for the time they use them.").

12 According to Rifkin, "1.7 million people globally are members of car-sharing services. A recent survey found that the number of vehicles owned by car-sharing participants decreased by half after joining the service, with members preferring access over ownership." See Jeremy Rifkin, The Rise of Anti-Capitalism, N.Y. TImEs, Mar. 15, 2014, at SR4, available at http:/ / www.nytimes.com/2014/03/16/opinion/sunday/therise-of-anti-capitalism.html?_r=0. 
space $^{13}$ sharing by persons on a sole-proprietor scale? ${ }^{14}$ Will 3D printing and other additive manufacturing techniques ${ }^{15}$ be enabled or hindered by zoning codes, authorizing equipment sharing in residential and other spaces not zoned for "compounding of materials"

13 See PARKIng PANDA, https://www.parkingpanda.com/how-it-works (last visited Sept. 11, 2015), (allowing advance parking reservation from computers or in real-time from mobile phones).

${ }_{14}$ The sole proprietors with "one off" or micro-scale operations (think of single person web-page designing for barter, for instance) are seemingly undetectable, therefore ungovernable in the literal sense. Thus, this sharing economy is replete with "outliers," exploiting new norms imbedded in this collaborative environment (as is true in any other form of economy); but they defy easy identification. See Dana Sauchelli and Bruce Golding, Hookers Turning Airbnb Apartments into Brothels, N.Y. PosT (Apr. 14, 2014, 2:19 AM), http://nypost.com/2014/04/14/hookers-using-airbnb-touse-apartments-for-sex-sessions /?utm_source=Sailthru\&utm_medium=email\& utm_term $=$ NYP $\% 20180 \% 20$ Day $\% 20$ Openers $\% 20$ and $\% 2030 \% 20$ Day $\% 20$ Signups\&ut m_campaign $=\mathrm{NY} \% 2520$ Post $\% 2520$ Newsletter. It seems likely that criminal justice systems will be more likely these outliers' interface - if any- with government regulation.

15 See generally, StePhen Hoskins, 3D Printing FOr Artists, Designers AND MaKers: TECHNOLOGY CROSSING ART AND INDUSTRY (2014). Nanotechnology will be the next breakthrough in home-scale production. See, e.g., K. ERIC DrEXLER, RADICAL Abundance: How a Revolution in Nanotechnology Will Change Civilization 77, 156 (2013) (discussing when this technology's equipment becomes affordable, products of modest size will be makeable from home on machines as small as desktop printers, using open-source digital design files). It may be closer than intuition suggests. See Junqi Li, Steven G. Ballmer, Eric P. Gillis, Seiko Fujii, Michael J. Schmidt, Andrea M. E. Palazzolo, Jonathan W. Lehmann, Greg F. Morehouse, and Martin D. Burke, Synthesis of Many Different Types of Organic Small Molecules Using One Automated Process, 347 ScIENCE 1221 (2015). Another breakthrough is the continuous liquid interface production (CLIP) process; continuous curing promises a quantum leap in additive production speed. See Rising from the Ooze, THE ECONOMIST (Mar. 17, 2015), http://www.economist.com/news/science-and-technology/21646537-quicker-wayprint-objects-rising-ooze. Those scoffing at the possibility of "citizen craftsmen" manufacturing from dwellings at the molecular level should recall that in only a few years' time, 3D printing venues morphed from research laboratories to dwellings, as equipment became smaller and affordable to everyday citizens. See, e.g., IAN GIBSON, David Rosen \& Brent Stucker, Additive Manufacturing Technologies: 3D Printing, Rapid Prototyping, and Direct Digital Manufacturing 33, 42, 171, 299 300, 482-85 (2015). Scant economic reason exists for rejecting a means to restore competitiveness to the nation and jobs to the "digi-proneurship" segment of the public. Cf. id. at 39, 385, 484. Gartner projects global end-user spending on the seven technologies constituting the 3D printer market will reach $\$ 13.4$ billion by 2018 , although it is unclear whether those users will have sufficient revenue to cover not only their production and overhead costs but also service, sales and channel development. See Press Release, Gartner, Gartner Says Worldwide Shipments of 3D Printers to Reach More than 217,000 in 2015 (Oct. 27, 2014), available at http://www.gartner.com/ newsroom/id/2887417. In the meantime, 3D printing service bureaus serve the production needs of developers, such as Shapeways. See Steve Rosenbush, 3-D Printing, Cloud Converge in New Business Services, Wall St. J. CIO Journal (May 26, 2015, 12:26 PM), http://blogs.wsj.com/cio/2015/05/26/3-d-printing-cloud-converge-in-newbusiness-services/?mod=WSJ_TechWSJD_cioJournal. 
and, for that matter, sharing the manufacturing spaces themselves among "makers?" 16

Sharing entrepreneurs generally desire to operate around shared tools and technologies. So-called "maker spaces" attract such providers; and their proximity to each other pays some dividends to the community due to synergies among ideas and economies of scale. But such spaces under Euclidean-grounded codes often are termed "manufacturing" or similar industrial-based uses violating earlier conventions separating blue-collar operations from residential, retail and other "cleaner" commercial activities. An initial paradox in attempting to assert land use controls over sharing entrepreneurs is this: Zoning law fundamentally seeks predictability in land regulation through structured lists of permitted uses in defined "districts" within its jurisdiction; ${ }^{17}$ but the sharing economy experiments continuously

16 Artisan's Asylum in Sommerville, MA, a 40,000 square foot, multi-tenant, community "maker space" thrives in a town in which its zoning code salubriously allows light industrial uses next to residential areas. See Juliet B. Schor, After the Jobs Disappear, N.Y. Times (Oct. 14, 2013), http:/ /www.nytimes.com/2013/10/15/opinion/after-thejobs-disappear.html?pagewanted=all; David Lang, Kickstarted: Finding Space (and Making a Makerspace), MAKE BLOG (Oct. 15, 2012, 4:06 PM), http:/ / makezine.com/2012/10/15/kickstarted-finding-space-and-making-a-maker space/. A "makerspace" is defined as a community center combining manufacturing equipment, community and education for the purposes of enabling community members to design, prototype and fabricate manufactured works impossible to create with the resources available to individuals working alone. These spaces of independent individuals sharing space and tools, can be hosted by for-profit companies, non-profit corporations, or organizations affiliated with or hosted within schools, universities or libraries. "Makerspaces represent the democratization of design, engineering, fabrication and education." How to Make a Makerspace, EVENTBRITE, http://www.eventbrite.com/e/how-to-make-a-makerspace-registration4585453214 (last visited Sept. 11, 2015).

17 Readers familiar with "form-based codes" stemming from New Urbanism principles may protest that these codes address the conflict of values described in this Article, but this assertion is incorrect beyond "optics." Form-based codes vary in type and extent, but generally place less emphasis on use as the basis for a code; instead, they "foster predictable built results and a high-quality public realm by using physical form (rather than separation of uses) as the organizing principle for the code." See Form-Based Codes Defined, Form-Based Codes Institute, "Form-Based Codes Defined," http://formbasedcodes.org/definition (last visited Sept. 11, 2015). Form-based codes encourage a variety of uses to be located near one another, but in a way that attempts to ensure they work well together and maintain a desired community character. Implicitly, then, the actual form and aesthetics of the area, engaging a mix of uses both attractive and walkable, creates cohesion and a somewhat-predictable neighborhood appearance. See Richard S. Geller, The Legality of Form-Based Zoning Codes, 26 J. LAND USE \& ENVTL L. 36, 53 (2010). Form-based codes' ability to create "visual harmony in the public realm," "continuous urban frontage to ensure a degree of uniformity," and control over spatial relationships in the built environment makes them useful governance tools. See Form-BASEd Codes Institute, supra note 17; Emily Talen, Design by the Rules: The Historical Underpinnings of Form-Based Codes, 75 J. Am. PLAN. Ass'N 144, 
with assets and technology, disrupting established business models. Indeed, some new Sharing Enterprise business models hardly resemble business activities to the outsider. ${ }^{18}$ This results in less predictability and an appearance that authorities and those governed work at cross-purposes. Nimbleness and iterative development of resource use are chief traits of sharing producers, foreign to the relative formulaic operations of Euclidean zoning regimes. A related paradox is that community land planning seemingly moves toward increasingly regional authority, while in the rich environment of sharing entrepreneurialism, the neighborhood ${ }^{19}$ appears a more sensible unit for planning activity. Transportation planning particularly appears destined for greater regionalism, but what happens within specific transit nodes increasingly seems destined to be governed by smaller governance units than the municipality. ${ }^{20}$

Adherents of a movement toward a "New Science of Cities" ${ }^{21}$ assert that understanding the intrinsic order of cities requires planners to undertake and endorse others' actions that create economic growth from networks of proximity, casual encounters and their economic "spillovers" in optimizing municipal performance. ${ }^{22}$ Any planning action therefore should promote social interactions known as knowledge exchanges, encouraging these economic spillovers. ${ }^{23}$ Advocates for social interaction find private infrastructure that

155-56 (2009). These codes do not, however, entirely eliminate separation of uses; instead, they prescribe "building functions," often in a simple matrix. See Geller, supra note 17, at 36. The issues pertinent to this Article are the purposes to which building interiors and surrounding streets of a neighborhood are put, and the resulting (often adverse) effects on traffic and parking congestion.

18 See Matt Hickman, Outdoor Living Meets the Sharing Economy at UK's First "ondemand" Garden Space, Mother NAture Network Blog (Aug. 11, 2014), http://www.mnn.com/your-home/organic-farming-gardening/blogs/outdoor-livingmeets-the-sharing-economy-at-uks-first-on (describing reservable "by the hour" private garden spaces as an alternative to public park visitation in Manchester, England).

19 In this Article, I will refer often to a distinguishable neighborhood or cluster of similarly situated (however organized for regulatory purposes) neighborhoods as a "District," meaning a designated local planning unit.

${ }^{20}$ See Stephen R. Miller, Legal Neighborhoods, 37 Harv. EnVTL. L. Rev. 105, 156-58 (2013).

${ }^{21}$ See, e.g., Michael Mehaffy, 5 Key Themes Emerging from the "New Science of Cities," AtLANTiC Citylab BlOG (Sept. 19, 2014), http:/ / www.citylab.com/design/2014/09/5key-themes-emerging-from-the-new-science-of-cities/380233/; Michael Mehaffy, What Can a "Science of Cities" Offer Planners?, Planetizen (June 25, 2014, 5:00 PM), http://www.planetizen.com/node/69957 [hereinafter "Mehaffy Planners"].

${ }^{22}$ See Mehaffy Planners, supra note 21.

23 See id. Local governments intuitively would encourage the sharing economy because it permits jurisdictionally-bound municipalities to grow their economies with minimal infrastructure costs or annexation battles calculated to increase the tax base. Miller, supra note 1, at 24. 
depends largely upon automobiles, telephones, and the Internetand the unsustainably high consumption of resources required to maintain their operations-less resilient than a system of physical urban place networks, whether public or semi-public spaces. ${ }^{24}$ Conventional planning, therefore, should abandon its focus on architecture and objects (ensuring visual order) that rely upon isolating, high resource-consumption systems and instead implement walkable, connected public realms inducing casual encounters among a wide network of acquaintances and strangers. ${ }^{25}$ This view endorses a certain magnitude of visual disorder in a dynamic organism like the city. ${ }^{26}$

This purportedly "scientific" view of cities holds that optimal performance follows ceding to residents some measure of land use control of their spatial structure. ${ }^{27}$ Naturally, sharing producers who wish to operate from their residences and "maker space" locales will find this notion initially satisfying. ${ }^{28}$ The balance of this article addresses whether-and if so, how-to accommodate dwellers while embracing scientifically-supported views that socio-economic "reactors" like cities must promote efficient exchanges and creative interactions among their citizens and visitors by accelerating physical interaction rates. Part II below describes persons forming and frequenting Sharing Enterprises and explains how the burgeoning sharing economy impacts the neighborhood model as a residential safe harbor from negative impacts typical of non-residential uses. Part III argues that even saluting their commitments to values like sustainability and trust demonstrated by most participants, unchecked operation of Sharing Enterprises leads to distrust and conflict among a neighborhood's stakeholders. Part IV assesses alternatives for land use governance of Sharing Enterprises and proposes an inclusive model balancing various stakeholders' agendas for their enclaves. Part $\mathrm{V}$ disposes with claims that no land use administration of Sharing Enterprises is optimal, while Part VI addresses how private land use governance may contribute to creating détente among district stakeholders. Part VII sums up why the sharing producer is not destined to become a fleeting figure in the urban landscape and, therefore, why minimizing the negative externalities of Sharing

24 See Mehaffy Planners, supra note 21.

25 See id.

26 See Jane Jacobs, The Death And Life of Great American Cities 222-23, 382-84

(Vintage Ed., 1992).

27 See Mehaffy Planners, supra note 21.

28 But see infra text accompanying notes 169-77. 
Enterprises must be addressed by the local administrations to preserve neighborhood expectations while promoting municipal competitiveness. Governments' special attention to defining a neighborhood to preserve the local character of (and retaining those "characters" who season) the urban fabric while driving high-value knowledge workers and tourists into the enclave is a daunting task. ${ }^{29}$ The challenge involves a reinvention of regulation by joining citizens and sharing producers as partners in flexible approaches to sharing risks and rewards of integrating these enterprises into our communities.

\section{THE PARAMETERS OF THE SHARED ECONOMY MOVEMENT, AND ITS SALUTARY FEATURES}

\section{A. Players in the Sharing Economy}

Five categories (listed below) of participants on the "producer" side populate the sharing economy. ${ }^{30}$ A permanent entrepreneurial class consisting of persons hovering near economic subsistence is one demographic constituent, remaining solvent by leveraging underused personal assets to share with others. ${ }^{31}$ These assets will consist of personal labor on a "one-off" hired basis and goods for loan like dwelling rooms, personal motor vehicles, clothes, tools, works of art, items of personal adornment and other expendable rental items. Redeployment of these goods hedges against their owners' economic uncertainty by creating new revenue streams. While selling one's goods and services in this fashion is hardly unprecedented-think, for

$29 \quad$ See Miller, supra note 1 , at 35.

30 The sharing economy has long-historic antecedents in the United States. During the 17 th and $18^{\text {th }}$ Centuries, money (script) was scarce, so many colonists relied primarily on bartering, with commodities such as beaver pelts, corn, musket balls, nails, tobacco and deer skins (from which we get our modern slang, "buck," meaning "dollar"). Everyone schooled in America during the $20^{\text {th }}$ Century learned of the "barter deal" of all time reportedly made in 1626 by Peter Minuit with local Native peoples, trading a valueless deed (Mana-hatin was not "titled" to any of the tribes) to twenty-two square miles of island for goods allegedly worth about sixty guilders, or $\$ 23.70$ in those times. See L.J. Krizner, Lisa Sita, Peter Stuyvesant: New Amsterdam AND THE ORIGINS OF NEW YORK 38-41 (2001) (stating that at best, this quit-claim deed deterred challenges by other native peoples to the "entitlements" of the New Netherland colony).

31 See Christopher Koopman, Matthew Mitchell \& Adam Thierer, The Sharing Economy and Consumer Protection Regulation: The Case for Policy Change 4 (Dec. 2014). 
example, of boarding houses ${ }^{32}$ and car-pooling ${ }^{33}$ - the magnitude of voluntary collaborative consumption is unprecedented.

Conventional "yard sale" or eBay "merchant" models ${ }^{34}$ will not cease; but there will be increasing emphasis on temporary ceding of an asset's use instead of permanent asset disposition. Sharing economy activists assess their assets and skill sets in this uncertain fiscal environment and unlock the value of their possessions and talents in unprecedented ways, leveraging their personal resources for others who gain by sharing in food, shelter, transportation, and other goods and services, such as know-how, on an individualized basis. ${ }^{35}$ The permanent sharing producer class will consist of a number of subsets, ${ }^{36}$ among them:

1. Senior citizens, retired on fixed incomes or their saved funds, leveraging their outright-owned assets like spare rooms and implements; ${ }^{37}$

2. Manually-skilled persons "moonlighting" from their residences outside regular work hours, fabricating goods or rendering services on their own time $;^{38}$

3. Micro-jobbers in the "knowledge economy" ${ }^{39}$ working on a

32 See generally Paul Groth, Living Downtown: The History of Residential HOTELS IN THE UNITED STATES 6 (1994).

33 See generally Selective History of Ridesharing, MIT “REAL-TIME” RIDESHARE RESEARCH (Jan. 24, 2009), http://ridesharechoices.scripts.mit.edu/home/histstats/.

${ }^{34}$ See generally eBay Merchant eCommerce Solutions Center, EBAY, http:/ / pages.ebay.com/merchantsolutions/whyebay/ (last visited Sept. 12, 2015).

35 See Dara Kerr, Vexed in the City: The "Sharing Economy's Hidden Toll on San Francisco, CNET BlOG (Aug. 20, 2014 4:00 AM), http://www.cnet.com/news/vexed-inthe-city-the-sharing-economys-hidden-toll-on-san-francisco/.

36 See, e.g., Leo Burnett, Meet the 6 Types of Sharers, Humans Being http:/ / humansbeing.leoburnett.com/\#/meet-the-6-types-of-sharers/ (last visited Feb. 26, 2015). Every sharing economy oriented website or paper endeavors to categorize participants (producers, consumers and prosumers) in some manner. See, e.g., Collaborative Economy Honeycomb 2-Watch it Grow, JeREmiaH OwYANG (Dec. 7, 2014), http://www.web-strategist.com/blog/2014/12/07/collaborative-economy-

honeycomb-2-watch-it-grow/ (noting twelve market sectors populated by Sharing Enterprises).

${ }_{37}$ See Rodney Brooks, Creative Ideas for Cash Flow in Retirement, USA TODAY, July 20, 2014, at 7B (illustrating revenue-generating options for dealing with shortfall in seniors' retirement funds).

38 Cf. Tamar Jacoby, This Way Up: Mobility in America, WALL ST. J., July 19, 2014, at C1-2, available at http://online.wsj.com/articles/this-way-up-mobility-in-america1405710779 (discussing how many future American jobs will require some sort of technical or practical training that emphasizes skills excluding producing things without manipulating computer programs).

39 See Knut Ingar Westeren, Introductory Comments to Foundations OF THE KNOWLEDGE ECONOMY, 1-2 (2012). In a knowledge economy, a significant part of a business' value may consist of its intangible assets, such as the value of workers' 
single-assignment basis as independent contractors from home-office space or other remote "third spaces," unaffiliated with an employer other than on a "jobbing" basis";

4. "Makers" exploiting cutting-edge technology like additive manufacturing devices (3D printers, for example), ${ }^{41}$ along with more conventional artisans continuing to work from home studios, renting their products from those spaces as ersatz galleries; ${ }^{42}$ and

5. "Hustlers," engaging in any income-producing method defraying recurring expense of living in cities without reliable means of financial support, including persons characterized as chronically unemployed or underemployed. ${ }^{43}$

intellectual capability, especially regarding use and applications of technology in producing and disseminating information. See Walter W. Powell \& Kaisa Snellman, The Knowledge Economy, 30 ANN. REv. SociOL. 199, 199 (2004).

${ }^{40}$ See Justin Fox, Breaking Down the Freelance Economy, HARV. Bus. REv. ENTREPRENEURSHIP (Sept. 2, 2014), https://hbr.org/2014/09/breaking-down-thefreelance-economy/.

${ }^{41}$ See Michael N. Widener, Begone Euclid! Leasing Custom and Zoning Provision Engaging Retail Consumer Tastes and Technologies in Thriving Urban Centers, 35 PACE L. REV. 834, 857-59 (2015).

${ }^{42}$ See, e.g., Geoffrey A. Fowler, MakerBot Replicator Mini Review: 3-D Printing Comes Home, Wall ST. J., June 17, 2014, at D1-2, available at http://online.wsj.com /articles/makerbot-replicator-mini-review-3-d-printing-comes-home-1403021932

(explaining how MakerBot Replicator Mini now enables persons to work from a residence to create 3D objects). Local Motors, a Phoenix-based 3D-printing company which built an entire automobile in 2014 with help from Oak Ridge National Lab and the manufacturing company SABIC, says it is the first to 3D print both a body and chassis (carbon fiber-reinforced plastic) together. Brian Fung, So, This Exists: A Working Car Has Been 3D-Printed Out of Carbon Fiber Plastic, WASH. Post The Switch Blog (Sept. 19, 2014), http://www.washingtonpost.com/blogs/the-switch/wp/2014/ 09/19/so-this-exists-a-working-car-has-been-3d-printed-out-of-carbon-fiber-plastic/.

Even if one accepts the notion that such printing is twenty years away from everyday citizens' access for a variety of reasons (product safety, cost, etc.), it is naïve to insist that large consumer products will not be built with the intention of shared use from individual residences and garages as soon as price and competence permits implementation.

43 See, e.g., Kevin Roose, The Sharing Economy Isn't About Trust, It's About Desperation, New York Daily InTElligencer/The Gig Economy (Apr. 24, 2014), http://nymag.com/daily/intelligencer/2014/04/sharing-economy-is-about-despera tion.html. See also Semiannual Monetary Policy Report to the Congress: Hearing Before the S. Comm. on Banking, Housing and Urban Affairs, 114th Cong. (July 15, 2014), available at http://www.federalreserve.gov/newsevents/testimony/yellen $201407 \quad$ 15a.htm (Testimony of Janet L. Yellen, Chair of the Bd. of Governors of the Fed. Reserve Sys.) ("Even with the recent declines, the unemployment rate remains above Federal Open Market Committee (FOMC) participants' estimates of its longer-run normal level. Labor force participation appears weaker than one would expect based on the aging of the population and the level of unemployment."). Some speculate that the persistent weakness in the labor force participation rate reflects adults working in the freelance economy. See Stephen Gandel, America's Biggest Job Market Problem is Uniquely 


\section{B. Principles of the Sharing Economy Movement}

The central elements of the sharing economy are an emphasis on sustainability and value creation through reuse of materials and objects; underpinnings of trust between and among producers, prosumers and consumers, ${ }^{44}$ and marketing of participants exploiting Web 2.0 platforms ${ }^{45}$ combined with an element of self-policing to evaluate and rate both providers and customers. ${ }^{46}$ Peer-to-peer communications capitalizing on expanding access to technology using open and collaborative design ${ }^{47}$ has spurred the idea that hospitality and generosity with one's costly privately-owned physical assets and talents can expand exponentially, thereby conserving non-renewable resources. Anthony Townsend muses that this is evidence of the "sociability of cities," propelled by the technologically-astute urban dweller's desire to connect, collaborate and share. ${ }^{48}$

The best argument for the essential sustainability of the sharing economy is that bartering with one's excess or underutilized-thus disposable or loanable-resources ${ }^{49}$ represents centuries-old social behavior. In America, sharing of resources is evident from the days of

American, ForTune FinANCE (July 2, 2015, 11:18 AM), https:// fortune.com/2015/07/02/us-labor-force-participation-drops/. It is unknown how many of such persons are paid in cash (or equivalents in goods or services) by others without declaring cash income or in-kind payments. Chairwoman Yellen's speech to the National Association for Business Economics Policy Conference was more sobering yet. See Janet L. Yellen, Chair, the Bd. of Governors of the Fed. Reserve Sys., Speech at the 2013 National Association for Business Economics Policy Conference: Challenges Confronting Monetary Policy (Mar. 4, 2013) (transcript available at http:// www.federalreserve.gov/newsevents/speech/yellen20130302a. htm).

44 See Juliet B. Schor and Connor J. Fitzmaurice, Collaborating and Connecting: The Emergence of the Sharing Economy, in HANDBOOK OF RESEARCH ON SUSTAINABLE CONSUMPTIOn 410, 416-17 (Lucia A. Reisch and John Thogersen eds., 2015).

45 See Uri Friedman, Airbnb CEO: Cities are Becoming Villages, The ATLANTIC (Jun 29, 2014, 9:51 PM), http://www.theatlantic.com/international/archive/2014/06/airbnbceo-cities-are-becoming-villages/373676/.

46 See KoOpman, supra note 31 , at 15-17.

47 See Anthony M. Townsend, Smart Cities: Big Data, Civic Hackers, and the QUEST FOR A New UTOPIA 153 (2013). Indeed, in the Internet universe, Tim BernersLee was the ultimate sharing economy founder, as his vision in inventing the Web was to facilitate particle scientists' publishing of aggregated data for sharing within that community. See Christopher Mims, Apps'Walled Garden Closes Off Wide-Open Web, WaLL ST.J., Nov. 17, 2014 at B1, available at http:/ / online.wsj.com/articles/the-web-is-dyingapps-are-killing-it-1416169934.

48 See TownSEND, supra note 47, at 162.

49 Ecologists call this phenomenon "niche construction"- that people (and even some other animals) will create new opportunities for themselves by making their habitats more productive in some way. See Matt Ridley, The World's Resources Aren't Running Out, WALL ST. J. (Apr. 25, 2014), available at http://online.wsj.com/ news/articles/SB10001424052702304279904579517862612287156. 
The Library Company of Philadelphia. ${ }^{50}$ Trading goods for services and goods for other goods, or renting goods or services, supports sustainability when that concept means limiting exhaustion of nonrenewable resources. ${ }^{51}$ While residence sharing, like that afforded through Airbnb, may not be substantially less carbon-intensive than staying at a hotel, construction of the hotel per se accounts for a significant fraction of its carbon "footprint.,"52

Importance of sustainability benefits aside, the key component of the sharing economy disrupting entire sectors of the global economy (such as the hospitality industry) is near zero marginal cost to sharing producers. ${ }^{53}$ Marginal cost is the cost of producing an additional unit of a good or a service once a business establishes its fixed costs. ${ }^{54}$ While a hotel chain must build a project to add inventory for consumers, Airbnb builds almost nothing in addition to occasional tweakings of its website. ${ }^{55}$ People merely connect to the Internet and other networks, as the "Internet of Things" ${ }^{56}$ expands; they can use big data, analytics, and algorithms to accelerate efficiency and lower the marginal cost of producing and sharing a wide range of products and services to near

50 In 1731, Benjamin Franklin convinced members of the Junto, his "society of mutual improvement," to pool their resources to purchase a collection of books no member could have afforded individually. Articles of Agreement were drafted on July 1, 1731, and the Library Company of Philadelphia was established when fifty founding shareholders signed on. Each founder contributed forty shillings and agreed to pay ten shillings per year thereafter. As the Library Company's collection grew, the book capital of each shareholder expanded as well. Later supported by taxes, until the $1850 \mathrm{~s}$ it was the largest public library in America. See generally The History of the Library Company of Philadelphia, THE LIBRARY COMPANY, http://librarycompany.org/about/history.htm (last visited Sept. 12, 2015).

51 Alex Stephany, The Business of Sharing: Making it in the New Sharing Economy 12, 16, 32-33, 184-85 (2015). See also Anne-Sophie Novel, Is Sharing More Sustainable? The Environmental Promises of the Sharing Economy, in A PLANET FOR LIFE: InNOvation for Sustainable Development 139-44 (Jean-Yves Grosclaude, Rajandra Pachauri, and Laurence Tubiana eds., 2014).

52 See TownSEND, supra note 47, at 163.

53 Rifkin, supra note 11.

54 See id.

55 See id.

56 This three-word term (abbreviated sometimes as the "IoT") refers to collections of physical objects linked to each other, and to users, through the Internet or other computer networks. Computers themselves are not usually thought of as belonging to the IoT, featuring objects like geo-positional tracking devices and home security systems that until recently were not linked through computer networks. See John A. Rothchild, Net Gets Physical: What You Need to Know About the Internet of Things, Bus. L. TODAY (The American Bar Association, Chi, Ill.), Nov. 2014, available at http://www.americanbar.org/content/dam/aba/publications/blt/2014/11/fullissue-201411.authcheckdam.pdf. 
zero. ${ }^{57}$ Economic rent-seeking shrinks when institutional gate-keepers traditionally tracking payments and asset movements in monitoring transaction completion are not the lone repositories of trust in commerce. ${ }^{58}$

City officials know that the sharing economy promotes community development and repatriates capital into neighborhoods ${ }^{59}$ : a transaction in the sharing economy promotes neighborhood economic investment more than a deal engaging a typical multinational corporation. A Forbes Magazine report estimated that the sharing economy generated $\$ 3.5$ billion for its participants. ${ }^{60}$ The sharing economy allows people to shorten the chains of commerce and ultimately to invest repeatedly and directly in their communities. Notably, sharing systems can be deployed rapidly, leveraging alreadyavailable Web technologies. Cataloging recent business models at length with collaborative-consumption users would be pointless since, while preparing this article for publication, myriad models of such sharing provision will rise and others will crash when no clear value proposition addressing an authentic need emerges. ${ }^{61}$ Today's marketniche dominant models will be surpassed by new models, while others adjust nimbly to capture new consumer opportunities. For instance, consider that Uber's origination featured limousine services, a very different model than its present operating system. ${ }^{62}$

Nonetheless, this economy offers cities several advantages in an entirely new development scheme, beginning with creating mixed-use

57 See Rifkin, supra note 11. The point is that disruption arises from the sharing economy's undercutting many established sectors' already dangerously-low profit margins.

58 See Paul Vigna and Michael Casey, The Age of Cryptocurrency: How Bitcoin and Digital Money are Challenging the Global Economic Order 4-5, 8, 62, 244 (2014).

59 See Resolution In Support of Policies for Sharable Cities, THE UnITED STATES Conference OF MAYORS, 81st Ann. MEeting (June 21-24, 2013), www.usmayors.org/resolutions/81st_Conference/metro18.asp.

${ }_{60}$ See Tomio Geron, Airbnb and the Unstoppable Rise of the Share Economy, ForBES (Feb. 11, 2013), http://www.forbes.com/sites/tomiogeron/2013/01/23/airbnb-andthe-unstoppable-rise-of-the-share-economy/. PricewaterhouseCoopers (PwC) reported in August 2014, its belief that by 2025 the potential value of the five main sharing economy "sectors" will be $\$ 335$ billion. See The Sharing Economy-Sizing the Revenue Opportunity, PwC, www.pwc.co.uk//issues/megatrends/collisions/ sharingeconomy/the-sharing-economy-sizing-the-revenue-opportunity.jhtml (last visited Sept. 12, 2015).

${ }_{61}$ See Marc-Arthur Gauthey, Why the Majority of Sharing Economy Start Ups Will Fail, Oui SHARE MAG. (Nov. 20, 2014), http://magazine.ouishare.net/2014/11/why-themajority-of-sharing-economy-start-ups-will-fail/.

${ }_{62}$ See Julian Chikkattu \& Jordan Crook, A Brief History of Uber, TeCH CRUNCH (Aug. 14, 2014), www.techcrunch.com/gallery/a-brief-history-of-uber/. 
enclaves out of strictly residential neighborhoods. ${ }^{63}$ The economic advantages include providing desired services to these enclaves' dwellers as well as consumer services not warranting traditional market-entrance brick and mortar stores and their higher price structures. ${ }^{64}$ Some sharing-economy models substantially impact land occupancy and burden spatial infrastructure and their dwellers. This article muses on neighborhood transformations occurring when unfamiliar persons appear in buildings, rights of way and curbside parking areas. Readers will think about models featuring home-based custom retailers, persons with rooms or offices to let ${ }^{65}$ food (fresh from the garden and prepared on the stove) and rides to share, and equipment and clothing to rent. The sustainability "value proposition" described in land use terms addresses whether sharing economy enterprises (and their on-site consumers in combination) afford more net benefit than nuisance to people jointly occupying the producers' spatial surroundings. ${ }^{66}$

\section{WHY THE SHARING ECONOMY REQUIRES LAND USE REGULATION}

Cities need uniformity in regulations, unless one believes "natural law" ${ }^{167}$ sufficiently governs activities springing up in neighborhoods. As Justice Scalia reminds us, one cannot conform one's behavior to the unknowable. $^{68} \quad$ Accordingly, in residential neighborhoods, municipalities historically have limited land uses that tend to introduce unfamiliar persons such as laborers and customers. ${ }^{69}$ Such regulated uses in residential areas include home occupations such as watching children in residences, after school-hours tutoring, musical and arts training, yard sales, and boarding houses and other congregate living

63 See Miller, supra note 1, at 11.

64 See id. at 12.

65 See, e.g., LIQUIDSPACE, https://liquidspace.com (last visited Sept. 12, 2015) (providing workspaces to rent by the hour, day, week, etc.).

66 Cf. NAvi Radjou \& Jaideep PrabHu, Frugal InNOVATION: How to do More With LESS xiv (2015) (describing the value proposition of doing better in business with fewer costs, greater sustainability and an enhanced sense of purpose).

${ }^{67}$ See John E. Donaldson, Regulation of Conduct in Relation to Land-the Need to Purge Natural Law Constraints from the Fourteenth Amendment, 16 WM. \& MARY L. REV. 187, 197, 200 (1974) (discussing the idea that property and liberty are natural rights protected by higher law undergirds "natural law"; legislation in appropriate instances must circumscribe natural rights, however, as in exercises of the police power, asserting that all land is held under a servitude in favor of the states).

68 Antonin Scalia, The Rule of Law as a Law of Rules, 56 U. CHI. L. REv. 1175, 117879 (1989).

${ }^{69}$ See, e.g., Emily TAlen, City Rules: How Regulations AfFect Urban Form 122 (2012) (noting that rules requiring functional separation are still the norm, so, for the most part, residentially zoned areas host strictly residential uses). 


\section{arrangements. $^{70}$}

Municipalities increasingly experiment with, and occasionally embrace, regulatory innovation enabling neighborhoods to thrive harmoniously with entrepreneurs leveraging new forms of collaborative consumption. ${ }^{71}$ If cities embracing regulatory change are more likely to thrive in economic development, job retention, and affordable housing production, the question is begged whether the evolving informal economy's impact on land use demands any regulation. If the answer is affirmative, here is why. First, a sharing economy potentially overtaxes parts of the infrastructure without sharing producers contributing in the way of offsets and mitigation of burdens. $^{72}$ Sometimes known as "fiscal freeloading,"73 this phenomenon applies to developments that increase demand for public services by a sheer growth in persons introduced into a community. For instance, owners who aggressively use Airbnb to rent their homes impose significant impacts on their neighbors, such as heightened traffic and noise ${ }^{74}$ generated on local streets. ${ }^{75}$ Renters of these properties may occupy curbside stalls otherwise allocable to local

${ }^{70}$ See generally, Nicole Stelle Garnett, On Castles and Commerce: Zoning Law and the Home-Business Dilemma, 42 WM. \& MARY L. REv. 1191 (2001); Thomas E. Roberts, The Regulation of Home Occupations under Zoning Ordinances-Some Constitutional Consideration, 56 TEMP. L. Q. 49, 49-50 (1983).

${ }^{71}$ For example, Los Angeles' Department of City Planning is experimenting with industrial mixed-use areas that may support limited residential units through its Hybrid Industrial Live/Work Zone. See generally Hybrid Industrial Live/Work (HI) Zone Quick Guide, L.A. DEPT. City PlanNing (June 10, 2015), http://planning.lacity.org/Documents/policy/HIZoneFAQandOrdinance.pdf. This guide contains a draft of the proposed Sec. 12.04.06 and text amendments to the Los Angeles Municipal Code. Ironically, Euclidean zoning arose from a perceived need to separate industrial uses from residences altogether for public health preservation.

${ }^{72}$ See, e.g., Daniel E. Rauch \& David Schleicher, Like Uber, But for Local Government Policy: The Future of Local Regulation of the Sharing Economy 15 (unpublished George Mason Law \& Economics Research Paper No. 15-01) (available at http:/ / poseidon01.ssrn.com/delivery.php?ID=83300402402908010909907312212312 70301020560890140950610750970841170740921110860130280280970230290261270 33125076028001016127018042042033065023028064100088021080091020049078082 03100409200808812201807602408100501012006609802912402702500312510107600 $3081 \& \mathrm{EXT}=$ pdf) (asserting that Sharing Enterprises lead to more intensive resource uses than anticipated by local regulation).

${ }^{73}$ See, e.g., Bradley C. Karkkainen, Zoning: A Reply to the Critics, 10 J. LAND UsE \& ENVTL. L. 45, 49 (1994) (addressing how new developments place a greater burden on public services than they contribute in new taxes).

${ }_{74}$ See Carolyn Said, Airbnb Irks Twin Peaks Neighbors, SFGate Blog (Aug. 14, 2014, 7:28 AM), http://www.sfgate.com/realestate/article/Airbnb-irks-neighbors5687123.php.

${ }_{75}$ See, e.g., Eric Biber and J.B. Ruhl, Regulating the "Sharing Economy, "REGBLOG (July 28, 2014), http://www.regblog.org/2014/07/28/28-biber-ruhl-regulating-thesharing-economy/. 
residents,${ }^{76}$ unless the property owner offers sufficient onsite parking space. Renters use the water and sewer systems; an overabundance of such renters in one neighborhood could overtax a city block's service capacity. Owners not maintaining their rental units may create problems for public health and sanitation ${ }^{77}$ if, for example, an owner fails to dispose of the rental unit's refuse routinely or neglects to service the "shared" swimming pool. The owner of property who lacks funds to make needed repairs may allow the improvements to become derelict.

Second, while well-planned rental business models may have vetted suppliers of goods and services, invariably there will be "knockoffs" of successful entrepreneurs in the sharing economy. Although imitation flatters, underfunded and inexperienced-management operations may endanger neighborhoods by luring poorly-screened producers and consumers alike. Rental units may become venues for drug dealing, stashing and use, ${ }^{78}$ prostitution $^{79}$ and other criminal conduct, or housing persons with infectious health conditions or chronic economic problems. ${ }^{80}$

Third, some sharing producers inevitably will "defect" from land use and related regulations just as they will from any social norm. ${ }^{81}$

${ }^{76}$ See Said, supra note 74. See also Karen Klinger, City Plan to Allow Residential Zipcar Parking Sparks Controversy, CAMBridge CMTY. TElevision (May 21, 2009), https://www.cctvcambridge.org/node/18076 (discussing objection to zoning change allowing ZipCar parking in residential areas because users will be "coming and going at all hours of the day and night" and will reduce available parking spaces for residents).

${ }^{77}$ See Said, supra note 74. Transient dwellers do not properly lid garbage cans, allowing animals access to the garbage inside.

78 In response to "raves," parties at which ecstasy is served and partiers dance for long hours, facilitating dehydration or drug toxicity leading to death, Congress passed the Ecstasy Anti-Proliferation Act of 2000 in October, 42 U.S.C. $§ 290 \mathrm{aa}-5 \mathrm{~b}$ (2012) and the Illicit Drug Anti-Proliferation Act of 2003, 21 U.S.C. $\$ 856$ (2012 \& Supp. 2004). Raves are conducted in residential areas in addition to clubs. See, e.g., Kent Page McGroarty, How to Throw an Awesome Private Rave at Home, SFGATE, http://homeguides.sfgate.com/throw-awesome-private-rave-home-24945.html (last visited Sept. 12, 2015).

${ }^{79}$ Dana Sauchelli and Bruce Golding, Hookers Turning Airbnb Apartments into Brothels, N.Y. PosT (Apr. 14, 2014, 2:19 AM), http://nypost.com/ 2014/04/14/hookers-using-airbnb-to-use-apartments-for-sex-sessions/?utm_source= Sailthru\&utm_medium=email\&utm_term $=$ NYP $\% 20180 \% 20$ Day $\% 20$ Openers $\% 20$ and \%2030\%20Day\% 20Signups\&utm_campaign=NY\% 2520Post\% 2520Newsletter.

80 See, e.g., AIRBNB HELl, http://www.airbnbhell.com/tag/airbnb-criminal/ (last visited Sept. 12, 2015), for anecdotal material.

${ }^{81}$ This fact illustrates why digital reputation and monitoring systems for selfpolicing in the sharing economy are critical. See Molly Cohen \& Arun Sundararajan, Self-Regulation and Innovation in the Peer-to-Peer Sharing Economy, 82 U. CHI. L. Rev. 116, 128 (2015) [hereinafter Cohen \& Sundararajan]. 
"Gaming" of a system is human nature and endemic in highly competitive scenarios $^{82}$ where an otherwise first-class operation suffers under low margins. Inevitably, such defection compromises public safety and the quality of life in the surrounding community. Moreover, tolerance of flouting established norms like zoning codes, without enforcement of standards, spurs disregard for the local regulatory system overall, contributing to a downward spiral of compliance and blighted conditions.

How do governments accommodate entrepreneurial freedom and fundamental property rights to the need for baseline community health and safety standards? Advocates say sharing creates jobs, cuts greenhouse gasses, reduces traffic (along with wear and tear on roads and bridges in addition to reducing exhaustion of raw materials used in vehicular construction), fights crime and even ameliorates the impact of natural disasters. ${ }^{83}$ In communities where "ownership" or possession of goods rapidly changes, cities facilitate citizens sharing their resources by reducing the volume and complexity of their regulations. Unregulated collaborative consumption transactions may endanger public welfare, regardless of consumer "verification," photos online, or ratings methods. ${ }^{84}$ For example, food exchanged via leftovers-sharing sites may have been prepared inexpertly or under unsanitary conditions, creating a potential public health hazard unpreventable by "peer" monitoring mechanisms. ${ }^{85}$ The typical consumer does not have the expertise to analyze a food-poisoning environment. Peer review and self-regulation foster a sense of community and may be cheaper to implement than centralized administration. Even so, existing trust and enforcement mechanisms do not require communities to disregard potential safety incidents,

${ }^{82}$ See Nigel Nicholson, How Hardwired is Human Behavior?, HaRv. Bus. Rev. (July 1998) (noting that humans are hardwired to avoid loss when comfortable, but scramble desperately when threatened and citing behavior of Nick Leeson, who destroyed Barings Bank by gaming the trading system).

${ }^{83}$ See STEPHANY, supra note 51, at 139-42.

84 See Brenden Mulligan, Dirty Pillows: The Unsolved Problems of Sharing Services, TeChCRUNCH (Apr. 1, 2012), http://techcrunch.com/2012/04/01/dirty-pillows-theunsolved-problems-of-sharing-services/.

85 Typically, in sharing-economy companies, after each transaction both the consumer and sharing provider are rated. These ratings provide transparency and accountability and induce sharing parties to provide quality service to protect their reputations. See, e.g., Rachel Botsman, The Currency of the New Economy is Trust, TEDGLOBAL 2012 (June 2012), http://www.ted.com/talks/rachel_botsman_t he_currency_of_the_new_economy_is_trust?language=en; Tom Slee, Some Obvious Things about Internet Reputation Systems, WHIMSLEY (Sept. 29, 2013), http:/ / tomslee.net/2013/09/some-obvious-things-about-internet-reputation-systems .html. But see infra note 119 and accompanying text. 
epidemics, or other improprieties imposing taxpayer costs resulting from a lack of express standards and professional enforcement. ${ }^{86}$

Another problem of unregulated sharing stems from introducing strangers into communities. ${ }^{87}$ Although raising this issue invites overtones of racism or other bias against unfamiliar persons, some who occupy temporary housing or visit meal-sharing venues investigate neighborhoods seeking targets for future burglary. ${ }^{88}$ Distinguishing transient residents from potential thieves is challenging enough, and no modestly-organized "block watch" program properly tracks multiple, subtle canvasses of possible targets for mischief unless the neighborhood has substantial collective efficiency. ${ }^{89}$

Even if no malice is intended, "sharing consumers" introduced into a neighborhood increase traffic movements (some of which, due to unfamiliarity with the neighborhood's streets, will create risk of collisions), fill parking spaces on local streets, generate additional ambient noise, and further burden electric and other utility grids proximate to the sharing sites. ${ }^{90}$ These neighborhood burdens often are not being addressed in the form of sales taxes or license fees

${ }^{86}$ See Cohen \& Sundararajan, supra note 81, at 126-27.

7 See Miller, supra note 1, at 34 (noting that sudden influxes of unfamiliar persons rapidly changes feeling of familiarity among locals).

${ }_{88}$ Sources support the finding that thieves case neighborhoods. See Victor Urbach, What Burglars Don't want you to Know, URBACH LeTter (Mar., 2010), http://www.urbachletter.com/Archive/Safety_1003_BurglaryPrevention.htm; cf. John Hughes, Home Alone (1990) (characters Harry Lime and Marv Merchants canvassing a neighborhood).

89 Neighborhoods with more transient residents and social disorganization tend to see increases in crime rates due to their weakened social control (where a community of concerned citizens is missing). See John C. Kilburn, et al., A Paper Tiger on Chestnut Lane: The Significance of NIMBY Battles in Decaying Communities, 4 URBANITES $3, \quad 7$ (2014), available at http://www.researchgate.net/profile/John Kilburn2/publication/269408776_A_Paper_Tiger_on_Chestnut_Lane_The_Significa nce_of_NIMBY_Battles_in_Decaying_Communities/links/548b14720cf225bf669f830 0 .pdf. Neighborhood "watch" programs are mostly ineffective in preventing crime; nor do they result in reduced fear of crime or increased information flow between citizens and law enforcement. See Jenny Fleming, "Working Together": Neighborhood Watch, Reassurance Policing and the Potential of Partnerships, TRENDS \& ISSUES IN CRIME AND Criminal Justice No. 303, 1, 3 (Sept. 2005), available at http://www.aic.gov.au/ media_library/publications/tandi_pdf/tandi303.pdf.

90 See, e.g., Cohen \& Sundararajan, supra note 81, at 122 (noting that an additional Lyft car on the road creates congestion and lengthens travel times for other drivers, while a noisy Airbnb guest in an apartment building might impose costs on the other residents from his or her disturbing behavior); Dean Baker, Don't Buy the 'Sharing Economy' Hype: Airbnb and Uber are Facilitating Rip-Offs, GUARDIAN TECHNOLOGY (May 27, 2014, 7:30 AM), http://www.theguardian.com/commentisfree/2014/may/27/ airbnb-uber-taxes-regulation ("Airbnb can also raise issues of safety for its customers and nuisance for hosts' neighbors.”). 
repatriated directly to the host enclaves. ${ }^{91} \quad$ Further, persons not participating in the sharing economy expect to maintain their daily routines without interference from unfamiliar persons, strange noises and odors, increased traffic and reduced curbside parking. ${ }^{92}$

Finally, controversy about the economic impact of regulating the sharing economy shows no signs of waning. Why should the land use control of the sharing economy be restrained? Does limiting regulatory restraint encourage entrepreneurism by eliminating costly overlays on businesses? ${ }^{93}$ Might entrepreneurism be stifled in an environment where "anything goes"? Does deregulation encourage institutional innovation as conventional companies compete for space in the innovation environment occupied by sharing producers?

Debate over whether or how to regulate the informal economy's land use dimensions shall not subside, because this burgeoning economy will not disappear. Technology will continue "introducing" sharing consumers and producers to each other, through "freelance" worker-contingent-employer platforms ${ }^{94}$ and otherwise. More individuals will be engaged over time in this economy because underemployment of the middle class and all non- or under-skilled workers is a chronic problem with no immediate solution in sight. ${ }^{95}$

91 Cf. Vicki Been, What's Fairness Got to Do With It? Environmental Justice and the Siting of Locally Undesirable Land Uses, in The Political ECONOMY OF INEQUALiTy 255-57 (Frank Ackerman ed., 2000) (noting undesirable land use siting implicates principles of environmental justice).

92 Accusations of NIMBY-ism notwithstanding, there is little immoral about a resident's wanting to live in a residential area not saturated with transients. See, e.g., Tani Sutley, Whatcom County and the New Sharing Economy, NoRTHWESTCiTIZEN (Dec. 9, 2014, 2:25 AM), http://www.nwcitizen.com/entry/whatcom-county-welcomes-thenew-sharing-economy.

93 Perhaps the test illustration will be Malibu, California, which has allowed shortterm rentals as of right without zoning regulation since 2009, so long as property owners register with the city and pay the same percentage transient occupancy tax that hotels remit. See Matt Stevens \& Martha Groves, Malibu to Crack Down on Short-Term Rentals via Airbnb, Other Websites, L.A. Times (May 27, 2014, 8:09 PM), http:/ / www.latimes.com/local/la-me-malibu-renting-20140528-story.html\#page=1.

4 See Lauren Weber \& Rachel Emma Silverman, On-Demand Workers: We are not Robots, WALl ST. J., Jan. 28, 2015, at B1, available at http://www.wsj.com/articles/ondemand-workers-we-are-not-robots-1422406524. The authors note that companies using this form of worker engagement now tout their workers as "micro-entrepreneurs of the vanguard of a new, flexible future of work in which people only do the jobs they like." Id. Essentially, these are options with no possibility of advancement and no benefits. Contingent arrangements permit business cost-savings by avoiding healthcare insurance premiums and retirement-system administrative expenses.

95 Full-time employment opportunities particularly are elusive in America's current economic and employer-mandated health-care circumstances, due to higher costs of retaining full-time workers. See Nick Timiraos, Many Face New Normal: Part-Time Pay, Full-Time Bills, WALl ST. J., Nov. 13, 2014, at A1 (video available at 
Indeed, some pundits blame technological developments for creating this problem. ${ }^{96}$ The class of youthful adherents to sustainability principles is growing. ${ }^{97}$ The number of persons with little or no savings is staggering, ${ }^{98}$ compelling many to address how to "cut corners" on everyday expenses. Additionally, evidence mounts that forthcoming generations of entrepreneurs are decreasing in numbers, ${ }^{99}$ suggesting that new business models in the knowledge economy will not place most of the underemployed and unemployed in full-time, subsistencewage positions, particularly in circumstances where workers lack crucial technical job skills. ${ }^{100}$ Finally, from rebellion, desire for schedule flexibility, or other reasons, some adults will not rejoin the conventional workforce whether or not jobs numbers grow. ${ }^{101}$

http://www.wsj.com/video/is-high-part-time-employment-the-new-normal/57FA23 DD-E5C3-4B03-B707-1448598161F5.html?KEYWORDS=timiraos+part+time). Given the American economy's recovery circumstances, while full time jobs have been added in 2014, the total number is short of jobs numbers during 2007, when America's recession commenced. See id. at A2. Timiraos speculates that part-time employment will replace full-time work, but cannot prove this theory given currently decreasing part-time U.S. jobs numbers. See id.

96 William A. Galston, Countering Tech's Damaging Effect on Jobs, WALL ST. J., Oct. 15, 2014, at A17, available at http://online.wsj.com/articles/william-galston-counteringtechs-damaging-effect-on-jobs-1413328435 (discussing how many jobs will be automated away over the next twenty years). Gartner reports that robots and other automated devices will perform one-third of all jobs within a decade. See Timothy Aeppel, What Clever Robots Mean for Jobs, WALl ST. J. TeCH (Feb. 24, 2015, 10:30 PM), http:/ /www.wsj.com/articles/what-clever-robots-mean-for-jobs-1424835002.

97 See Jeremy L. Caradonna, Sustainability: A History 2, 205-06 (2014).

98 See, e.g., Rani Molla, Americans Have a Hard Time Covering Emergency Expenses, Wall St. J. The Numbers Blog (Aug. 13, 2014, 10:09 AM), http:/ / blogs.wsj.com/numbers/americans-have-a-hard-time-covering-emergencyexpenses-1698/ (noting that Americans have little savings, and perhaps twenty-five percent of Americans have none at all, making emergency expenses difficult to cover); see also Ann Carrns, Why it's Hard to Build Emergency Savings, N.Y. TIMEs Bucks BloG (June 25, 2013, 1:08 PM), http:/ /bucks.blogs.nytimes.com/2013/06/25/why-its-hardto-build-emergency-savings/?_r=0 (noting that half of Americans have less than three months of expenses saved up, and just a quarter have six months of expenses saved, which is the typical recommendation for emergency financial reserves, according to Bankrate.com's report based on a 2013 survey by Princeton Survey Research Associates International).

${ }_{99}$ See Mitchell E. Daniels, How Student Debt Harms the Economy, WALL ST. J., Jan. 28, 2015, at A15, available at http:/ / www.wsj.com/articles/mitchell-e-daniels-how-studentdebt-harms-the-economy-1422401693 (discussing that the percentage of younger people reporting owning part of a new business has decreased as has the percentage of business begun by Americans under thirty-four years of age; and former-student debt magnitude seems to correlate to new venture formation).

${ }_{100}$ See Mark Trumbull, Unemployment, Inc.: Six reasons why America can't create jobs, Christian SCI. MONITOR (Sept. 2, 2011), http://www.csmonitor.com/Business/ 2011/0902/Unemployment-Inc.-Six-reasons-why-America-can-t-create-jobs.

${ }_{101}$ See Kate Taylor, Why Millennials are ending the 9 to 5, Forbes WOMAN (Aug. 23, 2013, 2:00 PM), http://www.forbes.com/sites/katetaylor/2013/08/23/why- 
In truth, no thoughtful person should want, outright, to stifle this phenomenon. Among other reasons, consider that:

1. Working at/from the home saves on office-based utilities consumed inside suites and in building common areas and on worker business overhead costs, so it is a sustainable business practice;

2. Having neighborhood proximity of consumers and producers builds familiarity with the neighborhood and strengthens immediate community ties, with the side effect of discouraging petty crime (the so-called "regulating functions" of sidewalk-level life ${ }^{102}$ );

3. This on-demand economy, bolstered by social media platforms, spurs entrepreneurism among workers in the knowledge economy and enables some financial support means for a shrinking class of workers;

4. Creating jobs, even if in small numbers, in the present chronic condition of unemployment and underemployment among the unskilled work force could result in a "virtuous cycle" of additional training and employment placement opportunities; $;^{103}$

5. Enabling a permanent class of small business owners/ partners, whether or not serial entrepreneurs (those building companies with intention of selling and cashing in), can produce diversity of business models for a protracted period, affording additional income to those engaged in the

millennials-are-ending-the-9-to-5/. A compelling social dimension of the sharing economy is experience consumption, opposed to goods acquisition, leading to heightened contentment in some younger persons preferring to spend disposable income on life experiences, economizing through borrowing instead of owing possessions. See Joel Stein, Baby You Can Drive My Car and Stay in My Guest Room. And do my Errands. And Rent My Stuff. My Wild Ride through the New On-Demand Economy, Time, Feb. 9, 2015, at 32, available at http://time.com/3687305/testing-the-sharingeconomy/. This partially explains why persons who do not need sharing platforms use them nonetheless. See id. at 40.

102 JACOBS, supra note 26 , at 60-88.

103 Following the recession of the later years of the 21st Century's initial decade, the challenge of replacing living-wage jobs is amplified by the rise of automation as a proxy for human workplace labor. See Derek Thompson, A World Without Work, THE ATLANTIC, http://www.theatlantic.com/magazine/archive/2015/07/world-withoutwork/395294/ (last visited Sept. 12, 2015). Some economists and other observers contend the sharing economy is not built to create long-term, stable jobs but instead is fostering downward mobility among Millennials. See, e.g., Reid Cramer, How the Sharing Economy is Hurting Millennials, Time (June 29, 2015), http://time.com/3939850/sharing-economy-pitfalls/; Monica Potts, The PostOwnership Society, WASH. MONTHLY (June 2015), http:/ /www.washingtonmonthly.com/ magazine/junejulyaugust_2015/features/the_postownership_society055896.php. 
"conventional" workplace; and

6. Reducing the personal habit of overconsumption, which heavily burdens certain non-renewable resources and contributes to mounting personal debt, ${ }^{104}$ is a positive behavioral modification.

Wealthy and underemployed micro-giggers alike will conduct small businesses in their (or their parents') homes, undetectably in many cases, unless they produce noxious by-products of their businesses or they self-identify to authorities as occupying workplaces. A reactionary community policy will not arrest this growing social norm. Part IV considers those instrumentalities of regulation ideally positioned and otherwise well suited to regulate this sector of social and economic life in America.

\section{HARnessing SHARING Economy LANd Use REgulation: PUblic AND PRIVATE INPUTS}

This Part addresses two themes: who possesses needed inputs and wisdom to regulate the collaborative consumption environment within conventional residential enclaves and whether Sharing Enterprises can be regulated without upending the ownership expectations of residents and the social equity underpinnings of sharing.

\section{A. Public Regulation of Sharing Economy Land Use Dimensions.}

Local American governments have experience in regulating land use and efficiency going back a century. Together with public faith in accountability of local government structures, this background favors continued local government-or perhaps regional governmentcontrol of new sharing economy business models and initiatives. Here are the arguments supporting this view. A precast system of reasonably stable $^{105}$ and precise laws and regulations discourages favoritism or exercising individual bureaucratic venality. ${ }^{106}$ When regulations are

104 See Claire Cain Miller, Is Owning Overrated? The Rental Economy Rises, N.Y. TIMES THe UpshOт BlOG (Aug. 29, 2014), http://www.nytimes.com/2014/08/30/upshot/isowning-overrated-the-rental-economy-rises.html?_r=0\&abt=0002\&abg=1.

105 See Jonathan Rothwell \& Douglas S. Massey, The Effect of Density Zoning on Racial Segregation in U.S. Urban Areas, 44 URB. AFF. REV. 779, 789 (2009) (providing that many local jurisdictions report that zoning regulations do not change much over time).

${ }^{106}$ Some critics assert that macro-level zoning regulations sustain segregation (a type of "favoritism") in communities with low-density residential zoning. See generally Rothwell \& Massey, supra note 105. See also Charles Lord \& Keaton Norquist, Cities as Emergent Systems: Race as a Rule in Organized Complexity, 40 ENVTL. L. 551, 584-99 (2010). Such critics also argue that zoning adjustment is rife with authorities succumbing to their own desires and fears as well as emotional responses of others who exert the most influence upon them. See Stewart M. Wiener, Comment, Substantive Due Process in the 
sufficiently explicit, they may be uniformly applied without fear of contamination by individual discretion; ${ }^{107}$ this predictability comforts many citizens. Additionally, the economic rationale for zoning adopted and enforced by public bodies states that land use creates positive and negative local externalities. ${ }^{108}$ Thus, while if a resident plants flowers in her front yard, her whole city block benefits; but filled with inoperable vehicles awaiting repairs, the resident's yard spoils her neighbors' streetscape and property values. A low-tech factory sited next to a suburb usually presents an eyesore. ${ }^{109}$ While a popular cafe may enliven a neighborhood, its patrons compete with adjacent residents for scarce curbside parking. Faced with such local externalities, principles of "market efficiency" cease to apply, as publicly administered zoning laws balance social welfare issues. Zoning rules seek to mitigate citizen-entrepreneur activities with negative externalities while encouraging activities with positive impacts. ${ }^{110}$ For instance, San Francisco's response to Airbnb-generated problems is legislation (a) allowing only permanent city residents to rent out rooms or entire homes, provided citizens enroll in a city registry and purchase liability insurance, (b) limiting rentals of full residences to ninety days annually and (c) providing for its Planning Department to enforce the new regulation. ${ }^{11}$

Twilight Zone: Protecting Property Interests from Arbitrary Land Use Decisions, 69 TEMP. L. REV. 1467, 1467 (1996).

107 Cf. Rob Imrie \& Emma Street, Regulating Design: The Practices of Architecture, Governance and Control, 46 URB. STUDIES 2507, 2507 (2009) (noting that building regulations, codes and rules are formulated to provide specific and predictable outcomes for all aspects of architectural production).

108 See Gideon Parchomovsky \& Peter Siegelman, Cities, Property, and Positive Externalities, 54 WM. \& MARY L. REV. 211, 214, 220 (2012).

109 See Nathan Smith, Zoned Out: Why and How We Should Seek to Restore a Free Market in Land, The FreEMAN (Mar. 18, 2014), http://fee.org/freeman/detail/zoned-out. An exception arises when the factory is adaptively reused for another purpose serving the residential population. See, e.g., Michael N. Widener, Tactical Urbanism v2: Dynamic Land Use Regulation and Partnership Tools Regenerating First Suburbs, 8 Drexel L. Rev. (forthcoming 2015) [hereinafter Widener, Tactical Urbanism]. See also Michael N. Widener, Renewed Energy: Sustainable Historic Assets as Keystones in Urban Center Revitalization, 32 QUINNIPIAC L. REV. 723, 744-47 (2015).

110 See Parchomovsky \& Siegelman, supra note 108, at 225.

111 See San Francisco, Cal., Ordinance 218-14 (Oct. 17, 2014), available at https: / / sfgov.legistar.com/View.ashx?M=F\&ID=3292337\&GUID=67C37394-6A6349DC-A886-675E294384C1 [hereinafter SF Ord.]. Highlights of the legislation include:

- All city residential buildings of two or more units are subject to this rental regulation;

- Residents who are not registered with the city but are found renting short-term after a complaint is filed are automatically in violation of the legislation;

- Registered residents must demonstrate compliance in the event of a complaint; 
The standard counterargument to employing precast systems imposed across diffused environments of entrepreneurism, is that central planning inflexibly values compliance over outcomes. ${ }^{112}$ Opponents of centralized planning may cite the City of Winona's rental-housing unit "percentage per block" ordinance as an illustration of this inflexibility. ${ }^{113}$ Adopted December 5, 2005 by Winona's City Council ${ }^{114}$ and affirmed by a task force appointed by it in $2010,{ }^{115}$ the ordinance limits rental housing units in a given city block to thirty

and

- Residents that violate the law (i.e., cannot demonstrate compliance) are "blacklisted" from listing their unit on all platforms until they achieve compliance.

Among stakeholder reactions was a lawsuit seeking injunctive relief filed by HomeAway, Inc., which claims the permanent resident restriction accommodates Airbnb's business model but not their clients' business models, many of whom do not live in the city. See HomeAway Inc. v. City of San Francisco, No. 3:14-cv-04859-JCS (N.D. Cal. Jan. 27, 2015). The suit also alleged the new ordinance violates the Constitution's interstate commerce clause by requiring companies providing "Hosting Platforms," defined as "a person or entity through which an Owner [or lessee] may offer a Residential Unit" for short-term use, to conform to a single business model or face legal penalties. See SF Ord., at 11. In short, the plaintiff concludes that the ordinance evidences the Supervisors' desire "to favor a local business at the expense of out of state competitors," instead of creating policies fairly treating residence owners regardless of their domiciles. See Complaint for Declaratory and Injunctive Relief for Constitutional Violations at If 64, HomeAway, Inc. v. City of San Francisco, No. 14-cv04859-JCS (N.D. Cal. Jan 27, 2015), 2014 WL 5510760. The United States District for the Northern District of California on January 27, 2015, granted the Defendants' motion to dismiss on several grounds, including lack of standing (Plaintiff owned no homes in the City). See HomeAway, Inc. v. City of San Francisco, No. 14-cv-04859-JCS, 2015 WL 367121 (N.D. Cal. Jan. 27, 2015).

112 See Philip K. Howard, The Rule of Nobody: Saving America from Dead Laws AND BROKEN GOVERNMENT 38 (2014).

${ }^{113}$ The zoning law's "Thirty Percent Rule" was aimed at diffusing private-sector student housing, which tends to be concentrated near the campuses of Winona State University and Saint Mary's University in Winona. See John Croman, Winona Faces Lawsuit over Rental Property Cap, KARE 11 BLOG (Oct. 26, 2011, 8:11 PM), http://www.kare11.com/news/article/944026/14/Winona-faces-lawsuit-over-rentalproperty-cap. Winona is intemperate, climatologically speaking, during much of the conventional August through May school year. See Winona, MN, Period of Record Monthly Climate Summary, Western Regional Climate Center, http://www.wrcc.dri.edu/cgibin/cliMAIN.pl?mn9067 (last visited Sept. 6, 2015). One reasonably assumes walking and biking to classes are challenging, inducing motor vehicle usage that is less sustainable (more carbon monoxide and particulate emissions and increased demand for parking lots) than a shorter walk or bike ride from more densely rental housing areas affords. This ordinance likely is incompatible with the stated mission of Sustain Winona, a collaboration of the city, Winona County and the area public schools and local universities. See SUSTAIN WINONA, http://www.sustainwinona.org/index.html (last visited Sept. 12, 2015).

114 See Winona, Minn. City Code ch. 33A, §33A.03(i) (2013).

115 Dean v. City of Winona, 843 N.W.2d 249, 254 (Minn. Ct. App. 2014). 
percent of the total dwelling units. ${ }^{116}$ There is no apparent reason why the "Thirty Percent Rule" identified the optimal percentage, although apparently it achieved some intended "dispersal of rental patterns" effect. $^{117}$

The argument against command-and-control style regulation further proceeds that centralized planning stifles innovation in producing goods and services by slowing the rate of innovation. Outright public bans on Sharing Enterprises are the worst offense in this regard, and banning or de minimis variations on bans will not engender compliance. ${ }^{118}$ Instead, many sharing producers will react to regulatory banishment by going farther underground, risking detection at a later time. ${ }^{119}$ This is because the very illegality of the sharing producer's operation-by avoiding costs of regulatory compliance-often affords her a competitive advantage over the established market players in an entrepreneurial space. ${ }^{120}$ Yet as one result of ineffective or piecemeal regulation enforcement weakening the community is the citizens' diminished trust in the rule of law, ${ }^{121}$ this anti-centralized regulation argument must be bolstered by advocacy for peer self-regulation. ${ }^{122}$ Furthermore, centrally planned regimes become rigid and increasingly distanced from "market-pricing" signals about efficient use of resources. ${ }^{123}$ Market flexibility and

116 In 2011, owners of houses in Winona challenged the rule in Minnesota state court, alleging the "Thirty Percent Rule" as an ultra vires act exceeding the city's zoning powers under the state's Zoning Enabling Act. See Minn. STAT. § 462.357 (2012), and violating their rights to equal protection, substantive due process and procedural due process secured by the Minnesota Constitution (Article I, Sections 2 or 7) and asking for injunctive and declaratory relief. The decision of the Minnesota Court of Appeals affirming the city's right to pass the ordinance on appeal to the Minnesota Supreme Court, was dismissed as moot; the high court found that appellants no longer had an interest in the appeal's outcome and "the case does not present the urgency and impact that were present in other cases that we have found functionally justiciable and of statewide significance" justifying an exception to the doctrine of mootness. See Dean v. City of Winona, 868 N.W.2d 1, 5 (Minn. 2015).

117 See Dean, 843 N.W.2d at 254. Mankato (MN) City Attorney Eileen Wells wrote in an amicus brief to Minnesota's Supreme Court: "Now and into the uncertain future, Minnesota cities need to be able to use all of the 'tools' within their authority, including the ability to limit the number of rental units, to fulfill their obligations to their citizens." Id.

118 Miller, supra note 1 , at 20.

119 See id. at 37. Miller correctly notes that the likelihood of monitoring all Internet sites marketing peer-to-peer sharing involving neighborhoods is highly remote.

120 See id. at 16.

${ }^{121}$ See id. at 25, 37.

122 See, e.g., Cohen \& Sundararajan, supra note 81 at 116 (arguing that resolving challenges of peer-to-peer regulatory challenges must include self-regulatory approaches).

See Smith, supra note 109. 
complementarily flexible public policies are critical in a time when technology will reorganize cities. ${ }^{124}$

Another fundamental shortcoming in zoning laws is that they operate at a higher-grained level than the individual level, ineffectively controlling the myriad of particular shared circumstances in cities and rural areas across our nation. ${ }^{125}$ Central planning is too removed from the local environment to address nuanced circumstances. Naturally, the knowledge of people in the neighborhood is one foundation of a community's successful planning. ${ }^{126}$ Their inputs are lost, however, when town planners believe themselves more knowledgeable than their citizens, so these "experts" listen less as a result. With the increasing complexity of cities as systems, they become less predictable and therefore less subject to good decision-making about resource allocation, management and related planning decisions. ${ }^{127}$ Indeed, when coordination of mass mobile and fixed technological devices reports individual actions and movements in real time, the need to "plan" anything diminishes. ${ }^{128}$ As the use of technology distinguishes minute variations in conditions between locations, centralizing plans and policies will increasingly be irrelevant. ${ }^{129}$ In the sharing economy, this translates to sophisticated controls imbedded in peer-to-peer marketplaces, such as digital "reputation systems" featuring detailed post-transaction ratings and identity-verification systems. ${ }^{130}$ There may be reason, however, to doubt the trustworthiness of the parties

124 See Peter M. Townroe, Urban Sustainability and Social Cohesion, in SuSTAINABILITY THE ENVIRONMENT AND URBANISATION 181-85 (Cedric Pugh ed., 1996); Balaji Srinivasan, Software Is Reorganizing the World, WIRED BLOG (Nov. 22, 2013, 9:30 AM), http:/ / www.wired.com/2013/11/software-is-reorganizing-the-world-and-cloudformations-could-lead-to-physical-nations/.

${ }^{125}$ Anthony M. Townsend, Life in the Real Time City: Mobile Telephones and Urban Metabolism, 7 J. URB. TECH. 85, 89 (2000).

${ }^{126}$ See, e.g., K. Al-Kodmany, Using visualization techniques for enhancing public participation in planning and design: process, implementation, and evaluation, 45 LANDSCAPE \& URb. Plan. 37, 38 (1999) (noting that access to community expertise and local knowledge produces better plans and designs).

${ }^{127}$ Townsend, supra note 125, at 89, 98-99 (arguing that diffusion of the decentralized networks of individuals renders urban theory (relying on "centralized thinking") ineffective to explain how cities function and ought to grow and, therefore, a new era is coming in which the individual ought to be the unit of planning analysis).

$128 I d$. at 96.

129 Id. at 101-02.

130 See, e.g., Arun Sundararajan, Trusting the 'Sharing Economy' to Regulate Itself, N.Y. Times ECONOMix Blog (Mar. 3, 2014, 12:01 AM), http:// economix.blogs.nytimes.com/2014/03/03/trusting-the-sharing-economy-to-regulateitself/?_php=true\&_type=blogs\&_r=0 (explaining that protocols verifying identity and screening suppliers lowers market failure risks by making suppliers and consumers feel safer, rendering government oversight less crucial). 
establishing platforms for citizen inputs. ${ }^{131}$ A 2014 study finds widespread discriminatory pricing on several popular e-commerce sites, revealing steering of consumers to sub-optimal "deals" and charging different sums for the same goods or services. ${ }^{132}$

Changes in identifying and analyzing those finer-grained details and manipulating technologies of data gathering in the realm of socalled "Big Data" 133 weigh in favor of continued municipal control of planning in a new milieu. Researchers gather data at street level to quantify urban life, save money and improve the quality of lives in their cities. $^{134}$ Tracking both cell phone activity of private citizens and readings from sensor packs mounted (among other places) on street lamps, city agencies can monitor dozens of activities and conditions, including hours when citizens turn on and off light fixtures in their residences, vehicular traffic counts, sound volume, wind speeds, pedestrian flows along sidewalks, and carbon-dioxide and other pollutants levels. ${ }^{135}$ In the near term, public data collection will come from "remote sensing" and "social sensing." 136 The former relies upon remotely-sensed data collected from a variety of devices such as radar, radiometer and LiDAR, ${ }^{137}$ collectively tracking the physical features of the surface of the landscape explored. ${ }^{138}$ In 2014, more than eleven billion sensors were attached to natural resources, production lines,

131 And trust levels are paramount even in self-regulating, as Elinor Ostrum noted: governing complex systems depends on good, trustworthy information processes including information pertaining to uncertainty and its magnitude. See Elinor Ostrum et al., Revisiting the Commons: Local Lessons, Global Challenges, 284 SCIENCE 278, 279 (1999).

132 See Elizabeth Dwoskin, Why You Can't Trust You're Getting the Best Deal Online, WAll St. J. Tech Blog, (Oct. 23, 2014, 12:01 AM), http://online.wsj.com/ articles/why-you-cant-trust-youre-getting-the-best-deal-online-1414036862? $\mathrm{mod}=$ trending_now_4. Several of these e-commerce sites investigated were leisure and hospitality industry-related, the same sector occupied by Airbnb. See id.

133 TownSEND, supra note 47, at 17-18, 29.

134 Elizabeth Dwoskin, They're Tracking When You Turn Off the Lights, WaLL ST. J., Oct. 21, 2014, at B1-2, available at http://online.wsj.com/articles/theyre-trackingwhen-you-turn-off-the-lights-1413854422.

${ }^{135}$ See id.

136 SeeYu Liu, et al., Social Sensing: A new Approach to Understanding Our Socio-Economic Environments, 105 ANN. Assoc. AM. GEOG. 512, 513, 515-16 (2015), available at http:/ /www.geog.ucsb.edu/ sgao/papers/2015_AnnalsAAG_SocialSensing.pdf.

${ }^{137}$ LIDAR is a remote sensing technology measuring distances by illuminating a target with a laser and analyzing the reflected light; it is frequently employed to make high-resolution maps, including 3D elevation maps of terrain, but has multiple applications in transportation as well as geospatial reckoning. See Michael J. Olsen, GUIDELINES FOR THE USE OF MOBILE LIDAR In TRANSPORTATION APPLICATIONS 1-3, 50 53 (2013).

${ }^{138}$ See id. 
electricity grids, logistics networks and recycling flows, as well as in homes, offices, stores and vehicles, feeding Big Data into the "Internet of Things." ${ }^{139}$ By 2020, experts project that at least fifty billion sensors will connect to that Internet. ${ }^{140}$

Social sensing involves spatially and temporally tagged data collected from location-aware devices such as mobile phones and GPS systems continuously operated and monitored by citizens. Social sensing devices detect social and economic features of the landscape, with the individual using her device in the role of "sensor." " In social sensing, there is greater temporal variation of activities than more static operations of remote sensing devices. ${ }^{142}$ Fusing such multi-source data, geospatial activities are analyzable through conventional image processing methods, leading to a vastly more complete picture of geographical environments. ${ }^{143}$

While issues like municipal invasion of privacy from such surveillance and the lack of transparency of data gathered for analysis are consequential, ${ }^{144}$ it seems less true today that local knowledge of people on the ground is both foundational and unknowable to community agencies. More interesting than debating who ought to harness land use policy is determining how data mined by "disruptive" technologies impacts centralized land use planning and the roles of the everyday citizen in analyzing, collecting, and manipulating streams of data and planning and executing suitable actions in the public interest. Commuter-parking mapping provides a common-sense illustration of the power of harnessed data streams. SmoothParking Inc. supplies a smartphone application guiding users to curbside parking zones indicating where it is-and shortly will become-legal to park, aiding both commuters and residents who will otherwise relocate their vehicles to avoid ticketing. ${ }^{145}$ Cities, the private sector and consumers all want the same thing from such parking data: ease of access. Greater accessibility minimizes frustration levels, which

\footnotetext{
139 See Rifkin, supra note 11.

140 See Dave Evans, The Internet of Things: How the Next Evolution of the Internet is Changing Everything, Cisco InTERnET Business SOlutions Group 1, 3 (Apr. 2011), https:/ / www.cisco.com/web/about/ac79/docs/innov/IoT_IBSG_0411FINAL.pdf.

${ }_{141}$ See Rifkin, supra note 11.

142 Id.

$143 \mathrm{Id}$

144 See Dwoskin, supra note 134, at B2. Privacy issues from this surveillance are not subjects of this Article.

${ }^{145}$ Javier Espinoza, Parking Spaces are a Perfect Niche, WALl ST. J. (Nov. 3, 2014), http:/ / online.wsj.com/articles/entrepreneur-finds-profitable-niche-parking-spaces1414965251. Recently, the application now allows commuters to identify available parking garages as well.
} 
prompts less rational risk-taking, conflicting traffic movements and collisions or "road rage" events.

Location (proximity of one land use or a single operation in its spatial context) will be merged with known consequences of thousands of minute transactions (such as social contacts) among citizens. This more accurately measures "capacity" and "saturation" impacts on surroundings arising from specific land use project proposals. ${ }^{146}$ Greater predictability of needed outcome mitigation in development project execution from real-time reporting and studying of street-level transactions in neighborhoods awaits the public. Analyzing this data with public inputs pertaining to neighborhood cultural values, history, and context will be more useful than planner's training-based assumptions or planning models based on historical data (such as parking demand or traffic trips' generation) about a project's expected consequences. ${ }^{147}$

\section{B. Private Regulation of Sharing Economy Land Use Dimensions}

"[Jane Jacobs'] critique of top-down planning was entirely consistent with the evolutionary biologist's understanding of cities." ${ }^{148}$ "[T] he planning elite 'completely failed to understand and respect the far more complex order that healthy cities already embodied. This complex order ... was the result not of big plans but of all the little plans of ordinary people that alone can generate the diversity that is the true glory of a great city." "149 "[U]rban design is as much art as it is science. It has to respond to countless local variables and idiosyncrasies." 150

Jacobsian micro-planning by ordinary citizens begins with a generalized view that cities are messy places, not centrally ordered but

${ }^{146}$ An example is in local government siting of public facilities (playgrounds, senior centers, etc.) inducing social interaction of various segments of a community's population; the intention is to optimize the location's support of individual well-being and neighborhood livability. See, e.g., Rejuvenating Neighborhoods and Communities Through Parks-A Guide to Success, National Recreation And PARK Association 8, 27 (2011),

http://www.nrpa.org/uploadedFiles/nrpa.org/Publications_and_Research/Researc $\mathrm{h} /$ Papers/Rejuvenating-Neighborhoods-White-Paper.pdf.

${ }_{147}$ See Al-Kodmany, supra note 126, at 40-41, 45.

148 TownSEND, supra note 47 , at 98.

149 Id. (quoting Robert Fishman, The Death and Life of Regional Planning, in Reflections on Regionalism 114 (Bruce Katz ed., 2000)). Jacobs' comments on diversity's contribution to complex order are contained in JACOBS, supra note 26, at 14, 394-95, 402-03. See also id. at 84 ("Working places and commerce must be mingled right in with residences ....”).

150 TownSEND, supra note 47, at 231. 
evolving mainly from the bottom upwards, and products of millions of individual and small group decisions and transactions, occasionally counter-balanced by top-down, centralized action. ${ }^{151}$ The primary argument against exclusively private regulation of land use dimensions of the sharing economy is: consumer trust, incorporating the wisdom of crowds expressed through crowd-sourcing behavior in marketing (by social media exposure), thereby endorsing or repudiating new business models through ratings sites ${ }^{152}$ however productive, does not alone curb "defection" from social norms required to maintain a community's public health and safety. ${ }^{153}$ Human nature demonstrates, when individuals share common resources or work together seemingly for mutual benefit, that some (called "free-riders" or "opportunists") seek to reap benefits without paying their associated costs, mandating mechanisms to build substantial cooperation among potential defectors over time. ${ }^{154}$ In theory, the sharing economy provides its own alternative to traditional legal protections via reputation and ranking systems. ${ }^{155}$ If consumers are constantly able to review the performance of producers, norm-defecting actors inevitably will "pay" under a

151 See Townsend, supra note 125, at 86 (quoting Michael BatTy, The New SCiEnCE OF Cities 14-15 (2013)) (identifying cities as more "biological organisms" than "mechanical machines" featuring some grand design and restoring equilibrium through periodic negative feedbacks such as regulation schemes).

${ }_{152}$ Rating sites reliability soon may be replaced by a trust "marketplace," in which consumers rely on personal networks and ratings of "raters" for vetting of vendors. $c f$. Nick Bilton, I Live in the Future \& Here’s How IT Works, 112-13 (2010). Bloggers already have made significant inroads in the "trust market" compared to prosumer sites like Yelp, which is a company under frequent attack for questionable ethical conduct that cannot seem to deflect credibly the accusations. See, e.g., How One Restaurant Fought Yelp's Alleged Extortion, Associated Press (Oct. 13, 2014), http://nypost.com/2014/10/13/restaurant-fights-yelps-alleged-extortion/; Eric Goldman, Court Says Yelp Doesn't Extort Businesses, Forbes TeCH BloG (Sept. 3, 2014, 12:20 PM), http://www.forbes.com/sites/ericgoldman/2014/09/03/court-says-yelpdoesnt-extort-businesses/. See also BiLTON, supra note 152, at 111-12.

153 See Tarun Wadhwa, Who's Looking Out for Consumers in the Sharing Economy?, HuFF Post TeCH Blog (May 5, 2014, 5:02 PM), http://www.huffingtonpost.com/tarunwadhwa/whos-looking-out-for-cons_b_5269138.html.

154 Sarah Schoenmakers, Christian Hilbe, Bernd Blasius \& Arne Traulsen, Sanctions as Honest Signals—The Evolution of Pool Punishment by Public Sanctioning Institutions, 356 J. TheORETiCAL Biology 36, 36-37 (Sept. 2014), available at http://ac.elscdn.com/S0022519314002392/1-s2.0-S0022519314002392-main.pdf?_tid=b9471a585b27-11e5-b9cf-

00000aab0f6b\&acdnat=1442266367_3cab50d7b54ccc134f50d92ad0ff3e6a. See also Christian Hilbe, Arne Taurlsen, Torsten Rohl \& Manfred Milinski, Democratic Decisions Establish Stable Authorities That Overcome the Paradox of Second-Order Punishment, 111 Proc. NAT'L ACAD. SCI. 752 (2014) available at http://web.evolbio.mpg.de/ hilbe/ Research_files/Hilbe \%20et\%20al\%20(PNAS\%202014)\%20Decocratic\%20decisions. pdf.

\footnotetext{
${ }^{155}$ See Wadhwa, supra note 153.
} 
hailstorm of public criticism. In practice, however, these group customer feedback systems can be opaque, guilty of varying credibility and uneven "enforcement." 156 If there is no sense of shame within "cheaters" among sharing providers, there are few barriers to flouting "trust norms" occasionally or serially. ${ }^{157}$ Unfortunately, peer punishment-where victims or third parties punish cheaters in the same circumstances as the defector-can be viewed as a type of selfjustice, subject to its own catalog of abuses like antisocial punishment and retaliation. ${ }^{158}$

Conversely, "pool punishment," featuring highly-visible sanctioning institutions, serves as a costly signal, inducing most defectors to cooperate over time. ${ }^{159}$ Such institutions are especially relevant in relatively "anonymous" communities; sharing producers, for one group, are too large to be aware of everyone's reputation. In such cases, mere notice of a central "sanctioning" body's existence improves cooperation. ${ }^{160}$ So, if private actors will implement punishment mechanisms and institutions, those non-public official stakeholders in the sharing economy must endorse appropriate cooperation levels within each business "type." Such is a daunting task when many stakeholders' own business models are so recent, and their lack of operating experience hampers private parties' crafting regulations and behavior standards applicable to a continuously evolving spectrum of business conduct. ${ }^{161}$ The novelty of a steady moral

156 See id.

157 See generally, June P. Tangney, Jeffrey Stuewig and Andres G. Martinez, Two Faces of Shame: The Roles of Shame and Guilt in Predicting Recidivism, 25 PsYCH. ScI. 799-805 (Mar. 2014). Perhaps the bigger problem in flouting norms is actors perceiving a small deviation from standards to be immaterial, ignoring the cumulative effect of myriad small violations-creation of sizable negative externalities in the community, $c f$. Miller, supra note 1 , at 20.

${ }_{158}$ See Schoenmakers et al., supra note 154 , at 37.

159 See id. at 40, 44.

160 See id. at 44. Conversely, these authors note, opportunists start cheating when it is apparent that there is no central punishment authority. Id. Such institutions are especially effective when they require a mix of different mechanisms such as secondorder punishment to induce fair outcomes and reliance on the signaling effect to reduce free-riding. $I d$. When individuals have to accept the decision of the majority, they prefer a society with second-order punishment. See Hilbe et al., supra note 154, at $752,755$.

${ }_{161}$ Cf. Alfredo Mendez, Startup Ethics: Is the New Sharing Economy Unfair for Workers?, MARCULA CTR FOR APPLIED ETHICS BLOG (Aug. 27, 2014), http:/ / www.scu.edu/r/ethics-center/ethicsblog/business-ethics-news/20343/

STARTUP-ETHICS:-Is-the-New-Sharing-Economy-Unfair-for-Workers?; Wadhwa, supra note 153 ("For an industry that claims to be built on trust, the companies that make up the sharing economy have adeptly avoided addressing these [trust] issues directly. When regulators have tried to bring up legitimate questions about safety and standards 
compass, one built typically (but not exclusively) by years of experience in independent living - an experience not native to youthful sharing producers and prosumers - only adds to this challenge. ${ }^{162}$

\section{Grass Roots Citizens' Regulation}

General plans, the "visionary" document guiding a city's planning intentions, ${ }^{163}$ result from thousands of conversations; these lead to decisions about proper balancing of a community's set of virtues. ${ }^{164}$ In organically slow-growing cities, these decisions are made incrementally on a small scale, responding to local needs and larger trends. ${ }^{165}$ Economies of scale and advancing "smart city" technologies, however, will usher in progressively more technocratic and frenetically paced real estate development. In this era, decisions by the administrative state might become less well-informed and increasingly ad hoc. ${ }^{166}$

To return to a more grass roots, "bottom-up" participatory approach to community master planning, officials ought to consider whether new agencies-such as micro-village governance structures, neighborhood citizen land use panels, and community benefits agreement managers-offer better monitoring and enforcement of zoning rules at the "granular" level of the neighborhood. ${ }^{167}$ The

these companies have been quick to paint themselves as innovators under attack by special interests. In some cases this is true, in others it's just a distraction from [addressing] a reasonable complaint."). See also infra Part VI (discussing challenges in private regulation of Sharing Enterprises).

${ }^{162}$ See Lauren Hudson, Who's Responsible for the "Moral Compass" of the New Economy?, GRASSROOTS ECONOMIC ORGANIZING, http://www.geo.coop/story/whos-responsiblemoral-compass-new-economy (last visited Sept. 12, 2015); Natasha Singer, In the Sharing Economy, Workers Find Both Freedom and Uncertainty, N.Y Times TECH. (Aug. 16, 2014), http://www.nytimes.com/2014/08/17/technology/in-the-sharing-economyworkers-find-both-freedom-and-uncertainty.html?_r=1 (discussing that micro-workers have little recourse against peer marketplace "hiring" firms when the companies for which they work on-call change their business models or pay rates or when consumers cancel reservations or service requests).

${ }^{163}$ Michael N. Widener, Moderating Citizen "Visioning" in Town Comprehensive Planning: Deliberative Dialog Processes, 59 WAYNE L. REv. 29, 31-32 (2013).

164 TownSEND, supra note 47, at 112.

165 See id.

166 See id.

167 Skeptics of such granularity should be reminded that in some Western nations, small scale local planning is mandated. In Germany, for instance, detailed development plans known as Bebauungsplan, provide developers following "zoning map and text" rules with the same legal certainty existing in most American communities; these plans dominate local land use administration and at times represent areas as small as a single city block. See Sonia Hirt, Mixed Use by Default: How the Europeans (Don't) Zone, 27 J. Planning Literature 375, 385-87 (2012). In Sweden, detaljplaner - detailed development plans outlining rules related to land use, bulk and density-may cover but one city block; Stockholm has more than 1,000 such plans. Id. 
following subsections consider the use of existing (and at times entrenched) citizen-based organizations to engage in small-scale land use regulation. These bodies may be loosely referred to as "legal neighborhoods," associations wielding certain quasi-political and legal tools to maintain order and exercise stewardship within their respective jurisdictions. ${ }^{168}$ The reader must understand preliminarily that municipalities lack the power to simply cede land use regulatory power to individual neighborhoods. ${ }^{169}$ While a few cities have attempted to delegate zoning powers to defined neighborhood groups, these efforts generally have not succeeded. ${ }^{170}$ Between 1912 and 1928, the United States Supreme Court issued three opinions (Eubank v. City of Richmond, ${ }^{171}$ Thomas Cusack Co. v. City of Chicago ${ }^{172}$ and Washington ex rel. Seattle Title Trust Co. v. Roberge ${ }^{173}$ ) holding that for the most part private property owners cannot regulate other property owners unless the controlling group deregulates a general prohibition on nuisances. ${ }^{174}$ These opinions effectively prohibited such delegation as unlawful abdication of a municipality's duty to protect the community's public health, safety and welfare against the arbitrary

at 387 .

168 See Miller, supra note 20, at 163-64.

169 See Kenneth A. Stahl, Neighborhood Empowerment and the Future of the City, 161 U. PA. L. REV. 939, 943-45 (2013) (arguing that as a result of this lack of authority, cities increasingly resort to BIDs as a "default option" to deal with a variety of localized urban planning issues).

${ }^{170}$ See, e.g., Shannon v. City of Forsyth, 666 P.2d 750, 752 (Mont. 1983) (invalidating a neighbor-consent provision related to the location of mobile homes under the authority of Eubank v. City of Richmond, 226 U.S. 137 (1912) and Washington ex rel. Seattle Title Trust Co. v. Roberge, 278 U.S. 116 (1928)); Cary v. City of Rapid City, 559 N.W.2d 891, 895-96 (S.D. 1997) (invalidating a neighbor-consent provision under Eubank and Roberge while ignoring Cusack); Am. Chariot v. City of Memphis, 164 S.W.3d 600, 602-05 (Tenn. Ct. App. 2004) (invalidating a landownerconsent provision allowing restaurant owners to waive a prohibition on where horsedrawn carriages in certain locations and distinguishing Cusack on the grounds that the ordinance here was for the benefit of the public, while the ordinance in Cusack solely benefitted local property owners); Williams v. Whitten, 451 S.W.2d 535, 536-38 (Tex. Civ. App. 1970) (invalidating a neighbor-consent provision regarding location of mobile home parks, citing Roberge); County of Fairfax v. Fleet Indus. Park Ltd. P'ship, 410 S.E.2d 669, 670, 673 (Va. 1991) (distinguishing Cusack, but nonetheless using Eubank principles to invalidate a provision conditioning zoning changes upon neighbors' consent). See also infra notes $171 \& 172$ and accompanying text pertaining to the United States Supreme Court cases.

${ }^{171}$ Eubank, 226 U.S. at 137.

172 Thomas Cusack Co. v. City of Chicago, 242 U.S. 526 (1917).

173 Roberge, 278 U.S. at 116.

174 See Alexander Volokh, The New Private-Regulation Skepticism: Due Process, NonDelegation, and Antitrust Challenges, 37 Harv. J. L. \& Pub. Pol'y 931, 941-43 (2014); See also City of Eastlake v. Forest City Enters., Inc., 426 U.S. 668, 677 (1976). 
exercise of selfish or coercive power. ${ }^{175}$ Nonetheless, a few cities have experimented with methods to confer land use powers upon neighborhood groups. ${ }^{176}$ On occasion, particularly powerful neighborhood groups in certain cities featuring citywide citizen participation systems have successfully integrated themselves into the political process, but this is a rare event. ${ }^{177}$ It seems that a key to viability among citizen-based organizations engaged in land use planning is that they be meaningfully constrained by a large, diverse governmental body counteracting any threats of exploitation or other welfarereducing actions by these entities. ${ }^{178}$

\section{i. "Planned Community" Citizens' Organizations: Adept} at Saying "No"

Associations of homeowners, or HOAs, arose as a means to offset tax burdens and to shift costs from residential developers to residents (through these associations) during and following project build-outs. ${ }^{179}$ Unfortunately, however, the operation of an HOA as a planningadvisory body faces too many hurdles. ${ }^{180}$ For instance, HOAs make

175 ARden H. RATHKOPF, DAREN A. RATHKOPF \& EDWARD H. ZIEGLER, JR., RATHKOPF’S The LAW OF ZONING AND PlanNING $§ 43: 15, \S 61: 30$ (2014) (As a "separate independent restriction or standard," a "consent requirement" may be held invalid as a "standardless and unlawful delegation of legislative power to a private group of property owners."); see Volokh, supra note 174, at 942-43 (citing Carter v. Coal Co., 298 U.S. 238, 311 (1936)); see also 8 Eugene McQuillian, Municipal Corporations § 25.35 at 111 (3d. ed., 2000) (explaining that zoning powers may not be delegated to private parties or property owners); Stahl, supra note 169, at 957-62 (citing Eubank, 226 U.S. at 137; Roberge, 278 U.S. at 116; and Thomas Cusack Co., 242 U.S. at 526). Stahl believes that the fatal flaw in neighborhood zoning districts is their "public-choice" foundation - that landowners "are permitted to exercise regulatory power in accordance with their own selfish interests rather than employing some notion of the public good." Stahl, supra note 169, at 962. The public-choice view of local government, Stahl explains, posits "that a homogeneous governing entity is more efficient than a heterogeneous one because [the former] can directly affect [sic] the unanimous will of the public without such inefficiencies of vote-trading, such as conflict, bureaucracy, pork-barrel spending, and wealth redistribution." Id. at 970 . Thus, the requirement of property owners' consent to change in land use typically is viewed as an unconstitutional delegation of legislative authority. See, e.g., Roberge, 278 U.S. at 122 ("A legislature may not delegate its authority to private persons over whom the legislature has no supervision or control.”); Emmett McLaughlin Realty, Inc. v. Pima Cnty., 58 P.3d 39, 41-42 (Ariz. Ct. App. 2002) (citing Indus. Comm'n v. C \& D Pipeline, Inc., 607 P.2d 383, 385 (Ariz. Ct. App. 1979)).

176 Jeffrey M. Berry, Kent E. Portney \& Ken Thomson, The Rebirth of Urban DEMOCRACY 141 (1993).

177 Id. at 289.

178 See Stahl, supra note 169, at 1004.

179 See Miller, supra note 20, at 161-62.

180 See John Whitcomb, The ZEC Guide: A Guide for Developing Zero Energy Communities 160 (2014) (positing that the leadership, innovation, and financial and 
operating decisions that impact narrow agendas, primarily keeping owners' fractional shares of maintenance costs economical and incoming while arresting improvements or other owner actions that appear to threaten property values (from the perspective of their boards' members). ${ }^{181}$ Additionally, HOA charters do not grant authority to forge relations with their governing jurisdiction or any other persons, "except as it might directly affect the HOA's operations." ${ }^{182}$ Further, an HOA's tendency to micromanage within its subdivisions misses the larger picture of community development impacts. ${ }^{183}$ HOAs as a whole illustrate the danger of disaggregating zoning power from other municipal functions and the attendant risks that zoning decisions will be made without consideration of their impacts on these other city functions. ${ }^{184}$

\section{ii. Citizen Planning Committees (Multilateral Associations) ${ }^{185}$}

An early illustration of citizen vehicles for growth-planning input was Detroit's Citizen District Councils, created by a 1945 Michigan law intended to stimulate urban growth while granting residents a voice in development. ${ }^{186}$ Council members were elected by residents and property owners of the zones they represented. While these council

technical expertise required for a zero energy community governing board "far exceed the capacity and operating capabilities required for a HOA.").

181 See Gary PoliakofF \& RYAn Poliakoff, New Neighborhoods: The Consumer's Guide to Condominium, Co-OP ANd HOA Living 70, 146-55, 206 (2009); Cohen \& Sundararajan, supra note 81, at 130.

182 See Miller, supra note 20, at 162.

183 See Cohen \& Sundararajan, supra note 81, at 131 (noting the "excessive restrictions" imposed by self-regulating HOAs); Miller, supra note 20, at 162.

${ }_{184}$ See William A. Fischel, Voting, Risk Aversion, and the NIMBY Syndrome: A Comment on Robert Nelson's "Privatizing the Neighborhood," 7 GEO. MASON L. REV. 881, 899-901 (1999); see also David L. Callies et al., Ramapo Looking Forward: Gated Communities, Covenants, and Concerns, 35 URB. LAw. 177, 197 (2003) (“[Any] privatized 'zoning' effort itself results in uncoordinated land use planning of the area. . . A Air quality, property values, environmental preservation, efficient public services, and well-located schools all are better coordinated by a more regional government responsible for the region's public services.").

${ }_{185}$ For discussions of these types of land use focused alliances, primarily non-profit corporations, see Jessica Spelke Jansujwicz \& Aram J.K. Calhoun, Chapter 10: Protecting Natural Resources on Private Lands: The Role of Collaboration in Land Use Planning, in Landscape-Scale Conservation Planning (Steven C. Trombulak \& Robert Baldwin eds., 2010). See also Tarry Hum, Planning in Neighborhoods with Multiple Publics: Opportunities and Challenges for Community-Based Nonprofit Organizations, 29 J. PlanNing EDUC. \& RESEARCH 461-77 (2010).

186 Nancy Kaffer, Duggan Must Find Way to Give Citizens a Voice, DetroIt FreE Press (Oct. 2, 2014), http://www.freep.com/story/opinion/columnists/nancykaffer/2014/10/02/citizens-district-detroit-orr-duggan/16549889/. 
members never wielded actual authority over planning decisions, they sometimes used their positions to block projects seemingly destabilizing to neighborhoods. ${ }^{187}$ Kevin Orr, Detroit's emergency manager, abolished these councils as he phased out his role in late $2014 .{ }^{188}$

Cities developing special zoning "vicinities" to protect specific enclaves or regions have spawned within the district boundaries' associations to interpret and apply detailed regulations for neighborhood preservation or enhancement. ${ }^{189}$ For example, the City of Phoenix has fifteen urban villages pursuant to its General Plan, each with a Village Planning Committee (VPC) providing guidance on a wide range of local and citywide issues, including those addressing implementation of the City's General Plan. ${ }^{190}$ A VPC's positions are advisory to the City Planning Commission and the City Council on matters involving new zoning initiatives or major amendments to the General Plan for the City. ${ }^{191}$ Its findings are not binding, and both the Planning Commission and City Council may act on cases without input from the affected VPC. ${ }^{192}$

San Francisco has more than twenty neighborhood commercial districts, each having a specific Planning Code section containing tailored regulations. ${ }^{193}$ Like Phoenix's Urban Villages, these districts originated in the $1980 \mathrm{~s}$ in response to perceived problems accompanying commercial growth in ten neighborhoods surrounding city commercial streets. ${ }^{194}$ Implementing so-called "formula retail"

187 See id

188 Id.

189 See Miller, supra note 20, at 149

190 See The Village Planning Handbook, City of Phx. Planning And Development DEPARTMENT,

https://www.phoenix.gov/pddsite/Documents/pdd_pz_pdf_00020.pdf.

191 Id. at 6.

192 Id

193 See Neighborhood District Zoning Control Table, S. F. Planning DeP'T (Sept. 22, 2008), available at http://www.sf-planning.org/Modules/ShowDocument.aspx? documentid=3561. All such regulations are found in Article 7 of the San Francisco Planning Code. S.F., Cal. Planning Code art. 7, \$§ 701-09 (2015), available at http://www.amlegal.com/nxt/gateway.dll/California/planning/planningcode?f=te mplates $\$ \mathrm{fn}=$ default.htm $\$ 3.0 \$$ vid=amlegal:sanfrancisco_ca $\$$ sync $=1 . \quad$ The use definitions for these districts, consisting of nearly sixty parts, appear at $i d$. at $\$ 790$.

194 See Mark Cohen, San Francisco's Neighborhood Commercial Special Use District Ordinance: An Innovative Approach to Commercial Gentrification, 13 GOLDEN GATE U. L. REV. 367, 369-70 (1983). One mission of these districts is to minimize dominance of formula retailers - merchants featuring formulaic floor plans and inventories capitalizing on economies of scale while deadening the shoppers' experiences of novelty and locality. 
establishments remains a persistent concern in these districts; such establishments trigger a conditional use hearing before the City's Planning Commission. In November, 2006, city voters passed a proposition whereby chain retailers operating eleven or more stores must receive a conditional use permit from the city to open a branch in a neighborhood commercial district. ${ }^{195}$ To approve the permit, the Planning Commission must find the applicant's tenancy both "necessary and desirable." Neighbors within the planning areas comment at the Planning Commission hearing in support of findings, and the commission has denied permits following neighbor inputs. ${ }^{196}$ To some fanfare, San Francisco Mayor Edwin Lee convened the city's Sharing Economy Working Group in March 2012, ${ }^{197}$ to explore means to encourage a "shareable city" 198 among its citizens. While this body may eventually address emerging planning issues concerning the sharing economy (possibly leading to additional Neighborhood Commercial Districts or modifications of existing regulations), it has never met from its public introduction through mid-2014, apart from a brief kickoff gathering in April 2012. ${ }^{199}$

\section{iii. Business Improvement Districts}

Due to its consultative nature, the Business Improvement District (BID) model provides slight insight regarding how to augment inclusiveness on a relatively small scale. ${ }^{200}$ BIDs restrict participation,

195 S.F., CAL. Planning CODE art. 7, § 703.3 (2015); see Formula Business Restriction, INST. FOR LOCAL SELF-RELIANCE (Jan. 16, 2015), http://ilsr.org/rule/formula-businessrestrictions/2321-2/.

196 See, e.g., Amy Farah Weiss, Support Local Economic Development, THE BAY CITIZEN BLOG (July 25, 2011, 1:53 PM), https://www.baycitizen.org/blogs/citizenblog/support-local-economic-development-4/.

197 Hunter Franks, The Civic Innovation System Blooms in 2012, SF MAYOR's OFFICE OF Civic InNOvation (Jan. 11, 2013), http://innovatesf.com/category/citizenengagement/.

${ }_{198}$ See DAvid Bollier, Think Like a Commoner: A SHORT InTRODUCTION TO THE Life OF THE COMMONS 134-35 (2014).

199 See Joe Eskenazi, City for Let: The Sharing Economy Proves it can Do Whatever it Wants, SF WeEkLY News (May 14, 2014), http://www.sfweekly.com/sanfrancisco/city-for-letthe-sharing-economy-proves-it-can-do-whatever-it-wants $/$ Content?oid=2949607; Patrick Hoge, Critics Slam Mayor Lee's Phantom "Sharing Economy” Working Group, S.F. Bus. Times (May $7, \quad$ 2014, $1: 49$ PM), http://www.bizjournals.com/sanfrancisco/blog/techflash/2014/05/mayor-leessharing-economy-task-force-never-met.html.

200 The initial establishment of a BID requires the support of the majority of affected land and business owners, so consultation underpins the existence of these public-private partnerships that exist to provide services formerly (or partially) in the government domain but also intervene in district land use planning decisions that are a prerogative of local government. See Elisabeth Peyroux et al., Business Improvement 
however, to business and property owners authorized by local ordinance to collect additional property assessments from their designated geographical areas to spend on additional services not provided (or underprovided) by their local governments. ${ }^{201}$ Saddled with limited goals, BIDs are less-perfect models of civic participation and lack those qualities of true deliberation and inclusion; ${ }^{202}$ for instance, "they fail to mix residents in the neighborhood with others who have stakes in the same area, such as educators, employers and environmentalists." ${ }^{203}$ This article provides no additional coverage to this model because rarely is it truly inclusive, as BIDs nearly always are self-interested and outcome-oriented instead of process-oriented. ${ }^{204}$

2. Newer Models of Citizen-Driven Organizations for Land Use Oversight

Airbnb's chief executive, Brian Chesky, told The Atlantic magazine in 2014 that trust, mediated by technology, was joining the paradigm of the village in making a comeback. Specifically, he said, "[a]t the most macro level, I think we're going to go back to the village, and cities will become communities again. . . . I'm not saying they're not communities now, but I think that we'll have this real sensibility and everything will be small." ${ }^{205}$ For Chesky's observation to become accurate, communities must first determine what properly scaled units of village regulation look like. Oregon, for instance, features small town-sized units that revise local zoning district maps and associated plans. $^{206}$ Yet, Oregon's state agency, the Land Conservation and Development Commission, regulates land use goals and guidelines,

Districts (BIDs): The Internationalization and Contextualization of a 'Travelling Concept,' 19 EUROP. URB. \& REG'L STUD. 111, 112-13 (2012).

201 See Barbara L. Bezdek, Citizen Engagement in the Shrinking City: Toward Development Justice in an Era of Growing Inequality, 33 ST. LouIs U. PUB. L. REV. 3, 15 (2013), Peyroux, supra note 200 , at 112-13.

202 See Bedzek, supra note 201, at 3, 15 .

203 Id.

204 See id. Peyroux, supra note 200, at 113 notes that the design of public spaces according to commercial interest of BIDs risks promoting land use policy that excludes "objectionable" social groups such as the less affluent.

205 Uri Friedman, Airbnb CEO: Cities Are Becoming Villages, THE ATLANTIC (June 29, 2014) http://www.theatlantic.com/international/archive/2014/06/airbnb-ceo-citiesare-becoming-villages/373676/.

206 An Introductory Guide to Land Use Planning for Small Cities and Counties in Oregon, OREGON DEP'T OF LAND CONSERVATION AND DEv. 2 (Jan. 2007), http://www.oregon.gov/lcd/docs/publications/introductory_guide_to_land_use_pl anning_in_oregon.pdf (explaining that local governments provide opportunities for citizen involvement and set standards for how certain types of land are planned and zoned; but these acts must conform to state planning goals). 
and ultimately determines if local-jurisdiction planning documents comply with those regulations ${ }^{207}$-irrefutably centralized planning. Disaster planning in some cities seems to be devolving to the smallest neighborhood units, but this type of planning is directed to lifethreatening emergencies-a different set of tools addressing different circumstances. $^{208}$

Advocates of localizing land use governance seek regulation from the base upwards, ${ }^{209}$ instead of from the apex downwards, without resolving the foundational question how, if at all, agencies of land use regulation survive separate from familiar trust-institutions from which residential dwellers sense familiarity and protection. The public's dilemma is whether we can ensure that the properly-scaled governance unit truly represents all sharing producers and residents within the unit's boundaries. Otherwise, as Mariana Valverde points out, local bylaws impose a set of culturally-biased ideals. ${ }^{210}$ Legal standards defining "cleanliness" and "tranquility," for example, mirror aesthetic and moral ideals of an established, usually ethnic majority, group. In many American cities, mostly white, middle-aged, middle- or upperclass property owners dominate rule-making, as these persons own most of the urbanized real property. ${ }^{211}$ Deciding who defines these ideals affords different ethnic and socioeconomic groups with varying degrees of legal protection, usually entrenching established inequalities. $^{212}$ Some sharing producers suspect regulations exist for improper purposes, such as protecting existing businesses, garnering community revenue and underwriting bureaucracy. ${ }^{213}$ As a consequence, these sharing producers prefer to remain out of sight and, when needed, seek subsequent forgiveness rather than

\footnotetext{
207 Paul G. Lewis, Shaping Suburbia: How Political Institutions Organize URBAN DEVELOPMENT 111-12 (1996).

208 See, e.g., Jim Carlton, San Francisco Readies for the Big One, a Block at a Time, WALL ST.J. (Nov. 19, 2014, 7:39 PM), http://www.wsj.com/articles/san-francisco-readies-forthe-big-one-a-block-at-a-time-1416443960?tesla=y.

209 See Karl Kehde, Collaborative Land Use Planning (4th ed. 2007); Roger J. Mason, Collaborative Land USE MANAGEMENT (2008).

210 Mariana Valverde, Everyday Law On the Street: City Governance in an Age OF DIVERSITY 49-54 (2012).

211 See id. at 49, 58-59.

$212 I d$. at 22, 78-79, 84-85. This bias, Valverde claims, is reinforced by city bureaucrats who enforce inherently biased rules, and local elected officials, who cherry-pick issues to champion based on interest group politics. See id. at 21, 80-84. Valerde calls the resulting system "village elder politics" and "rule by aesthetic." See id. at $103-05,227$.

213 See, e.g., Scott Beyer, The Motor City's Regulators Are Hitting the Brakes on Regrowth, WALl ST. J. (Dec. 13, 2014, 6:25 PM), http://www.wsj.com/articles/scott-beyer-themotor-citys-regulators-are-hitting-the-brakes-on-regrowth-1418426736.
} 
permission from administrators at the outsets of their endeavors. ${ }^{214}$ Accordingly, a sub-city regulatory unit desiring credibility must learn of the sharing producers and prosumers dwelling in that district and involve them, intimately, in the regulatory decision-making process, to assure them that their inputs will be thoughtfully considered.

This engagement imperative is more easily spoken than achieved. Residents, especially long-time neighbors resistant to change, have legitimate claims that "they arrived first," and that "they built this community" through their investments of money and energy. It requires conditioning to educate such residents that a healthier mix of people facilitates exchanges of trade, labor and sociability-producing more robust community life. ${ }^{215}$ Next, it is important to persuade intransigent dwellers that introducing maker spaces and home businesses does not mandate visiting unfair cost burdens upon established communities, so long as a plan is implemented first to ensure that new neighborhood entrants mitigate negative externalities and otherwise offset increased economic burdens to the enclave. ${ }^{216}$

On the part of sharing producers and prosumers, initial education includes wresting their acknowledgement of the long-time neighbors' claims and conceding that multi-party deliberation, not asserting "operations entitlement" as a matter of fundamental property rights, better promotes acceptance of new business models within residential areas. Deliberation means genuinely discussing problems and proposed solutions to them and in the process: (a) justifying each faction's preferences to the others; and (b) indicating willingness to refine those preferences under conditions of public reasoning, mutual respect, recognition of the other faction's legitimacy and inclusion of inputs from differing interests. ${ }^{217}$

214 See $i d$.

215 Cf. Bezdek, supra note 201, at 5.

216 See, e.g., LuigART Maker's Spaces, FAYetTe Alliance (Sept. 18, 2014), http://fayettealliance.com/luigart-makers-spaces/ (providing that a site inventory and analysis is conducted to establish the baseline conditions of a proposed project, including a maximum vehicular use study, in turn forming the basis for written guidelines by which the Planning Staff and Planning Commission can evaluate future development plans associated with the project). In October, 2014, Article 22 of Lexington-Fayette County, KY's Zoning Ordinance was amended to establish a Planned Unit Development-2 (PUD-2) ZONE. See Lexington-FayetTe County Ky., ZONING ORDINANCE art 22B, available at http://www.lexingtonky.gov/ Modules/ShowDocument.aspx?documentid=29196.

${ }^{217}$ Bezdek, supra note 201, at 9. See also id. at 32-35 (describing deliberative components and decision-making methods). In effect, such deliberation will be a form of district-wide "visioning." See Widener, supra note 163, at 35-36, 39-46 (describing district-wide visioning in greater detail). As Professor Bezdek notes, funding in redevelopment occurring under the federal Community Development 
Thus far, the existing neighborhood mechanism that seems most adaptable to the deliberation model is the negotiated contract. Community Benefits Agreements (CBAs) may be the result of sharing entrepreneurs' negotiated peace with skeptical adjoining neighbors instead of agreements with planning administrators. Under CBAs, the sharing producers must "pay it forward" by contributing to the infrastructure, like Internet and communications technologies' (ICT) upgrades or "marketplace" enhancements within the District (such as installing bicycle racks), accommodating persons intimately affected by the later arrivals' activities. Under such agreements, the following sorts of stipulations may frame the sharing producer's operation entitlements:

a. Neighborhood enforcement mechanisms set forth by community-based non-profit organizations;

b. Sanctions including the forfeiture of cash bonds or the posting of other monetary security posted as a pledge of continued performance of standards, such as limiting noise levels, hours of operation, and traffic and parking generation; and

c. Mandatory conciliation among disputants prior to involving government authorities in prosecuting actions over violations of the District's bargained-for agreement.

Many of these conventions are highly appropriate to the conditions of the sharing economy's injection into the community. The flaw in these contractual solutions is that agreement takes too long to reach, especially when multiple stakeholders engage in negotiations. Without some preexisting system in place (similar to a payback or repayment agreement, under which, upon commencing operation, each sharing producer in turn makes some fair-share cash payments in return for "setting up shop" in a District) under a prearranged "master" agreement governing all similarly situated Sharing Enterprises, formal agreements consume substantial time when reached between the District and each sharing producer seriatim.

Block Grant Program is conditioned upon preparing and executing a citizen participation plan. Bezdek, supra note 201, at 13. 
3. A Proposal for Inclusiveness of Stakeholders in Sharing Economy Districts

The following structure involves stakeholders' inclusion in determining proper integration of sharing producers in a neighborhood. It borrows somewhat from Los Angeles' Neighborhood Councils, which have been in effect since City Charter revision in 1999. ${ }^{218}$ Los Angeles has ninety-five neighborhood councils that intend to be diverse, inclusive, and representative of all community stakeholders and to be catalysts for change in addressing the needs of their individual communities. ${ }^{219}$ This network of councils is overseen by the Board of Neighborhood Commissioners (the "Commission"), which is itself an inclusive body comprised of seven persons with diverse backgrounds and geographic locations appointed by the Mayor and confirmed by the City Council. ${ }^{220}$ The Commission meets twice monthly unless special meetings are called. ${ }^{221}$ The proposed structure might be staffed by a city employee (preferably a planning staff member) to be the Districts' "information officer" overseeing a robust public website, giving regularly-scheduled briefings and providing technical assistance to what are known below as "District Councils."

The District Councils govern certain planning aspects within each District, defined by the community as one or more self-identified neighborhoods sharing a common character due to ethnic composition, geographic delimitations, or some other community of

${ }^{218}$ About Us, L.A. NEIGHBORHOOD COUNCIL COAL., http://www.lancc.org/ (last visited Sept. 12, 2015); see L.A., CAL., City Charter art. IX, $\$ \$ 900-914$ (2015), available at

http:/ / www.amlegal.com/nxt/gateway.dll/California/laac/administrativecode? $\mathrm{f}=\mathrm{te}$ mplates\$fn=default.htm\$3.0\$vid=amlegal:losangeles_ca_mc; L.A., CAL., AdmIN. CodE, div. $22, \S 22.801 \quad$ (2015), available at http://www.amlegal.com/nxt/ gateway.dll/California/laac/administrativecode? $\mathrm{f}=$ templates $\$ \mathrm{fn}=$ default.htm $\$ 3.0 \$$ vid =amlegal:losangeles_ca_mc; L.A., Cal., Ordinance, 174006 (effective May 31, 2001), available at http://www.lacityneighborhoods.com/Documents/PlanOrdinance.pdf (implementing the plan for the citywide system of councils).

219 Commission, EMPOWERLA: DEP'T OF NEIGHBORHOOD EMPOWERMENT, http://empowerla.org/commission/ (last visited Sept. 12, 2015) [hereinafter EmpowerLA]; $c f$. Bedzek, supra note 201, at 48-49 (emphasizing the importance of identifying those who usually are voiceless or deliberately excluded from input in order to maximize credibility and neighborhood acceptance of the process). According to the implementing ordinance, a proposed Neighborhood Council should represent approximately 20,000 residents at a minimum. L.A., Cal., Ordinance 174006 (effective May 31, 2001).

220 EmpowerLA, supra note 219.

221 Id. 
interest. ${ }^{222}$ Following their appointment by the community's planning commission, ${ }^{223}$ these Councils begin their work by conducting a public "convention" at which, after public deliberation, ${ }^{224}$ they identify sites where sharing producer operation is optimal and establish compatibility categories. ${ }^{225}$ Effectively setting forth these propositions as a sort of mini "general plan," ${ }^{226}$ the Councils are tasked with overhauling that plan at short-duration intervals (between three to five years), and reviewing, after public deliberation, the efficacy of the plan at even more frequent intervals (perhaps annually). ${ }^{227}$

Equipped with a schedule of compatibility categories, ${ }^{228}$ cityappointed hearing officers, being persons not living in the district, initially apply these standards to applications for Sharing Enterprise operation within a neighborhood. The hearing officers impartially receive evidence and testimony on a proposed sharing producer's use from the applicant, who testifies under oath. The hearing officers are asked presumptively to approve each application, ${ }^{229}$ subject to

${ }^{222}$ Cf. Timothy A. Holveck, Land Use Lingo: A Glossary of Land Use Terms, Wisconsin DEP'T OF NATURAL RESOURCES 19 (2001), http:/ / www.kalkaskacounty.net/downloads/ land_use_lingo.pdf.

${ }^{223}$ Appointment by Planning Commissioners (in those communities where they are not elected officials) does not ensure fewer "patronage" appointees than if the city's legislative body appoints them; but such a method may render members less prone to member "obligation-discharging"-if the planning commissioners themselves are not prone to "deal-making." (In some communities, the Council and the Planning Commission have identical memberships.)

${ }^{224}$ I use this term deliberately to differentiate it from the venue of a public hearing which, as Professor Bedzek notes, affords no real deliberative dialog among attendees and tends to be vitriolic instead of civil. See Bedzek, supra note 201, at 33, 35.

${ }^{225}$ See infra Part IV.C.

${ }^{226}$ Cf. Richard White, Mini-downtowns a Growing Trend in Calgary's Growth, CALGARY Herald (Nov. 19, 2014), http://calgaryherald.com/life/homes/condos/white-minidowntowns-a-growing-trend-in-calgarys-growth (noting that city's adoption of "major activity centers" around the city after extensive community engagement).

${ }^{227}$ Cf. Sofia Ranchordas, Does Sharing Mean Caring? Regulating Innovation in the Sharing Economy, 16 MinN. J.L. SCI. \& TECH. 413, 450 (2015). Professor Ranchordas suggests that because innovations arise incrementally, regulators should implement flexible regulations in a continuous process of experimentation and learning, and those regulations optimally incorporate a sunset clause. See id. at 450-51. This experimentation model seems suited to District determinations such as siting "enclaves" for aggregated Sharing Enterprises and reexamining its compatibility categories; implementing some Sharing Enterprises allows for District "test case" review and deliberation on whether (or not) to rework compatibility categorization or to adopt zoning overlay districts to regulate sharing producers. Too-frequent revision of plans on the District (or the community-legislative) level, however, reflects an ad hoc approach undermining confidence in residents concerned about predictability and safety.

${ }^{228}$ See infra Part IV.C.

229 See Miller, supra note 1, at 7 ("[T] he regulatory response should be based upon 
stipulations of approval ("Conditions"), ${ }^{230}$ unless that evidence or testimony adduced establishes that the proposed Sharing Enterprise is deemed likely to be highly incompatible, in which event the hearing officer can deny the application altogether. In either event, the hearing officer assigns the specific compatibility category (based upon the Councils' initial work) she deems suitable based upon hearing evidence.

If the hearing officer's approval of the application is protested, the matter is next subject to conciliation, ${ }^{231}$ conducted by a public official or her designee, between the applicant Sharing Enterprise and protestors. If the conciliation does not lead to an accommodation agreement, ${ }^{232}$ the protest next is heard by a subcommittee of the Council established without any participant residing in the impacted District. This appellate body has no authority to modify the proposed use's specific compatibility category; and it will uphold the hearing officer's determination of denial of an application unless, by a supermajority vote of that body (the majority vote's percentage being tied to the compatibility category), it is determined that the Sharing Enterprise has adequately addressed mitigating negative externalities. If the Council's subcommittee upholds the denial of the permit, the sharing producer must wait a minimum of six months before reapplying to the Council for the same or a similar Sharing Enterprise on the same street, ${ }^{233}$ or a minimum of ninety days before re-applying

regulating the entry of the sharing economy platform into the existing market, as well as the new market created.").

${ }^{230}$ See Miller, supra note 1, at 44 (citing "good neighbor" rules like noise stipulations requiring a "quiet time" and limiting commercial activity during evening hours, parking regulations addressing on-street parking and parking permits in residential zones, and trash guidelines).

231 By "conciliation," I mean a conference involving the stakeholders and a neutral person whose goals are to maintain civility and to attempt to generate an atmosphere of mutual trust. Mediation, while often useful, renders the conference directed by a trained expert (whose expenses must be paid by the parties), a person who may be more interested in the deliberation process than in the inclusion of resident and sharing producer inputs, or another party with no experience in trust-building methods. A District Council member with no stake in the particular application's outcome or relationship to a stakeholder may be appropriate to "moderate" the conciliation meeting, if she is properly trained in her role.

${ }^{232}$ The accommodation agreement, if reached, would be forwarded to the Hearing Officer for review, to determine whether the agreement has addressed the issues identified by that official in reaching the compatibility category. In such event, the Hearing Officer may reopen the hearing for the purpose of making a revised determination, perhaps incorporating the conditions discussed by the conciliation's participants.

${ }^{233}$ The "cooling off" period serves to allow further consultation among the stakeholders and further refinement of the Sharing Enterprise's business model in 
in the same District but in a substantially different location within its boundaries. The sharing producer applicant further can appeal the Commission's denial to the community's Planning Commission, ${ }^{234}$ but must first submit a narrative to that body that explains in detail those modifications and mitigation efforts the Sharing Enterprise will make, responding to issues raised by protestors in the conciliation meeting that caused the applicant's failure to receive approval.

If the hearing officer's approval of the sharing use is not protested or ultimately "upheld" over a protest, then, upon securing any needed business license, the exterior of the building housing the sharing use will be physically tagged ${ }^{235}$ to identify Sharing Enterprise approval. A Council review of the Sharing Enterprise operation must be conducted shortly after the anniversary of commencement of that use..$^{236}$ No matter how the Sharing Enterprise is finally approved, if it "fails" its anniversary review or is the subject of later enforcement due to violation of the Conditions, the approval tag will be replaced with a new or "reprogrammed" tag, indicating the Sharing Enterprise has violated the Conditions or other applicable laws and, therefore, that the use is scheduled for a hearing on revocation of the approval. ${ }^{237}$ Any city agency, a membership trade association to which the sharing user belongs, or the Council shall have the right to act as complainant to revoke the prior city approval.

This process entails a good deal of bureaucracy compared to existing special exception and dimensional variance hearing processes. On the other hand, this proposal offsets much of the recurring criticisms that variance-granting bodies pay little to no attention to legal limitations on their powers ${ }^{238}$ and that public

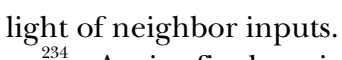

234 Again, final say in a municipal zoning matter must be voiced by a municipal legislative body. See supra text accompanying notes 155-67.

235 The author suggests tagging by using, on a building's exterior, any of a QR Code plaque, a Near Field Communication (NFC) and an accompanying information tag (or an unpowered NFC chip) or some future form of "visible light communication" (such as that being developed by Fujitsu under its "Li-Fi" technology). See Keith E. Mayers, Lazaros Kyrillidis, Konstantinos Markantonakis and Song Dong, A Brief Comparison of NFC Smart Posters and Quick Response Codes, NFC \& CONTACTLESS 74-78 (2012), available at http://www.crisptelecom.com/files/nfcworld.pdf.

${ }^{236}$ This is not to support an elaborate bureaucracy but to ensure that the applicant did not misrepresent his or her true operating intentions and possible neighborhood repercussions.

237 Additionally, any trade group incorporating the Sharing Enterprise identified by the applicant will be notified to encourage that group to sanction the sharing producer by private penalization.

${ }^{238}$ See, e.g., Randall W. Sampson, Theory and Practice in the Granting of Dimensional Land Use Variances: Is the Legal Standard Conscientiously Applied, Consciously Ignored, or 
hearings are not deliberative moments, becoming platforms for emotionally-driven outcomes or the airing of prearranged outcomes instead. ${ }^{239}$

\section{Determining Sharing Enterprise Neighborhood Compatibility Standards}

" $[\mathrm{P}]$ recisely the many small-scale nonresidential uses on the street ... are responsible for much of the increased attractiveness and value of the street for residence... . [T] hey make the street interesting and safe." "[N] 240 arguments arise over their desirability. The arguments ... revolve around the question of what kind of [zoning] categories ... will be least at odds with the needs of real life."

The community should establish standards, following hearings before the Councils, ${ }^{242}$ on Sharing Enterprises' levels of compatibility with any District's special character and circulation patterns. ${ }^{243}$ While Districts' inputs are instrumental, the community ultimately must have final say on compatibility through its general or comprehensive plan, nearly always a creature of enabling legislation for urban planning. ${ }^{244}$ This is because District boundaries likely are the centers of municipal

Something in Between, 39 URB. LAW. 877, 894-905 (2007).

239 See Bedzek, supra note 201, at 16, 26-27; JACOBS, supra note 26, at 406 ("In many cases . . . it has all been decided before they are heard.”).

240 JACOBS, supra note 26 , at 236.

241 Id. at 235. Jacobs' grievance with "monotonous" city zoning categorization was that it confused scale of use, instrumental in neighborhood planning, with kind of use; Jacobs argued that the latter dimension, misapplied, would lead to visual "street disintegration." See id. at 234-38. To Jacobs, segregating uses no matter their size or empiric effect needlessly suppressed diversity of street life. See id. at 238. The very same large-scale fragmenting of the street's visual harmony causes other negative externalities like traffic generation, street parking consumption, heightened levels of noise and other sensory overloading. While all those impacts may not be perfect recipes for neighborhood "tranquility," a certain quantum of these impacts are part of street activation-in short, the cost of place-making. This constitutes a District question of balancing the costs and benefits of these externalities.

${ }^{242}$ See infra notes 249-52 and accompanying text at subparts A-E, infra.

243 Indeed, some Districts may propose municipal adoption of overlay or special planning zoning districts by the City Council or other principal legislative body of their community allowing, as of right, living and working arrangements within the same structure. See, e.g., Robert Steuteville \& Philip Langdon, New Urbanism: Comprehensive RePORT \& Best Practices Guide § 6-6-6-7, 10-20 (2003) (explaining that terms employed are "flex house" (or unit) and "shopfront house" (or unit)).

244 See Charles M. Haar, The Master Plan: An Impermanent Constitution, 20 LAW \& ConTEMP. PROBS. 353, 353 (1955). While neighborhood level planning is advocated in some quarters, these plans must be compatible with the core strategy of the local authority (and formally adopted by that authority) to be effective. See HUGH BARTON, Marcus Grant \& Richard Guise, Shaping Neighborhoods: For Local HEALTH AND Global Sustainability 8 (2010) [hereinafter BARTON \& GRANT]. 
streets or edges (or centers) of other public spaces and because the impacts of some uses are felt in adjacent Districts or perhaps more regionally, such as in the community's transit network. Next, the community must have final approval rights because in many states, the statutory scheme requires the approval of a general or master plan at the elected local community official level. ${ }^{245}$ Legislative bodies have, and must continue, to decide the proper mix of land use classes, although local governments should not dictate specific locations of these uses within a District's boundaries without citizen input. ${ }^{246}$ But a city's legislative body must ensure that a minority fraction of the Districts are not disproportionately (and unwillingly) hosts of these uses-unless less risk-adverse or more entrepreneurial Districts affirmatively seek additional Sharing Enterprises' inclusion within their boundaries. ${ }^{247}$

The community must likewise assist the Districts in determining their individual "saturation points," as it has the legal responsibility to

245 See State of California General Plan Guidelines, GOvernor's OfFICE OF PlANNING \& RESEARCH 3 (2003), available at http://opr.ca.gov/docs/General_Plan_ Guidelines_2003.pdf (stating that each county and city must adopt a comprehensive, long term general plan); ARIz. Rev. StAT. ANn. § 9-461.06(C), (M) (2015) (West) (illustrating a statute governing municipal planning that requires the "governing body" of an Arizona municipality to adopt the general plan).

246 The City of Seattle uses the phrase "live-work unit," defining it as: [A] structure or portion of a structure: (1) that combines a commercial or manufacturing activity that is allowed in the zone with the residential living space for the owner of the commercial or manufacturing business, or the owner's employee, and that person's household; (2) where the resident owner or employee of the business is responsible for the commercial or manufacturing activity performed; and (3) where the commercial or manufacturing activity conducted takes place subject to a valid business license associated with the premises.

Seattle, Wash., Muni. Code., § 23.84A.024(L). By definition, Seattle live-work units can have a commercial or manufacturing component if it would otherwise be allowed in the zone. Seattle's Residential-Commercial zone allows live-work units and the following commercial uses outright: personal and household retail sales and services, medical services, restaurants, business support services, offices, and food processing and "craft work." Id. $\S 23.46 .004(\mathrm{~B})$. In Seattle, live-work units are considered compatible with these uses. Seattle limits the size of individual businesses to 4,000 square feet. See id. $\S 23.46 .014$. This provision limits the size of businesses, thereby ensuring that large businesses that would jeopardize the residential character of the neighborhood will not be included.

${ }_{247}$ In that event, the entrepreneurial District should familiarize itself with model code provisions for live-work units, such as those found in Sustainable Land Use Code Project, CAPITOL REgION COUncil OF GOVERnMENTs 1-3 (June 2013), http://www.sustainableknowledgecorridor.org/site/sites/default/files/CRCOG_Liv e-Work_Units_Final_9-30-13.pdf. See also Model LAND-DEvelopment Regulations 7174 (Marya Morris ed., 2008), available at http://austintexas.gov/sites/ default/files/files/Planning/CodeNEXT/PAS_556_4_2_live-work.pdf. 
do so and possesses better intuition about the regional burdens than a Neighborhood Council with narrower interests than regional implications. ${ }^{248}$ The compatibility levels of the proposed uses will populate the following spectrum:

A. Inherently incompatible uses, where noise, traffic generation, or other nuisance-oriented factors render a use essentially dangerous or substantially diminish the quality of life in surrounding enclaves. In this category, a rare permit grant will satisfy the classic variance inquiry, in which the applicant essentially would be deprived, by rejection of the application, of all economically viable use of the property; ${ }^{249}$ and even here, for relief, the applicant would need to provide substantial (likely expensive) mitigation of negative externalities. One anticipates the District's residential-dwelling spokespersons always will oppose the application and (in all likelihood) propose some alternate use of the property implicating its acquisition (whether voluntarily or involuntarily) for the community leadership's consideration. The applicant will probably be required to present some expert testimony on the extent of nuisance elements (such as a traffic study or noise measurement by an engineer). Presumptively, the application for a use permit in this category will fail in nearly all cases.

B. Incompatible without substantial mitigation where, albeit not per se nuisance-creating (as characteristic in the preceding category), the use requires thorough addressing of its direct and indirect impacts, whether by reducing the hours of the proposed use's operation or physical treatments, like implementing noise-dampening materials, odor filtration,

${ }^{248}$ An unavoidable point is how to address the District that seeks to classify all Sharing Enterprises as "inherently incompatible," meaning none shall be allowed in its boundaries. Market forces may persuade sharing producers to avoid such intolerance and exclusion in the first instance, preferring those Districts that are" most exuberantly diversified." See JACOBS, supra note 26, at 255. However, to encourage all Districts minimally to deliberate upon the utility of increasing mixtures of uses and the benefits of such diversity, it will be important to appoint to a Neighborhood Council's board membership numbers of sharing producers or prosumers who live within the District's boundaries. It is worth remembering that solidly residential enclaves may already have in place contractual restrictive covenants (or General Plan boundaries) permitting no commercial activities. If there are none of these, the sharing producer may wish to negotiate first a Good Neighbor Agreement, followed by an application for a permit.

Cf. Lucas v. S.C. Coastal Council, 505 U.S. 1003, 1015 (1992) (noting that situations exist "where regulation denies all economically beneficial or productive use of land"). 
smoke-scrubbing, or other substantial mitigation. (If licensing of this category of uses were privately controlled, "trade group" members might require this mitigation as a condition of that body's licensing.) One illustration is the operating of an outdoor batting cage for hitting instruction conducted nightly for three-hour intervals on a residential lot, involving multiple youth baseball teams. Limiting operating hours to before a typical citizen's bedtime, compelling acoustical treatment of vibrating-bat noises and requiring shielding of outdoor pole lighting sources all may contribute to the acceptability of this use; but the permit's application may fail upon District resident opposition, especially if opponents demonstrate that acceptable alternatives for the Sharing Enterprise's location exist within the District's boundaries.

C. Incompatible prosumers, where projected volumes of nonlocals-based traffic generation or behaviors exhibited by visitors to this same or analogous type of use predictably disturbs the District's equilibrium. ${ }^{250}$ A motorcycle repairs teaching and tools-lending facility illustrate this circumstance. ${ }^{251}$ While the facility's operation may be professional, inability of the neighbors to know with confidence who their street's visitors are and what the noise level will be, coupled with history of such operations elsewhere in the community, may lead the District to question how much this activity contributes to its quality of life. ${ }^{252}$ In

${ }^{250}$ Cf. Aisles Apart, ECONOMIST 36 (Mar. 21, 2015), available at http://www.economist.com/news/china/21646794-protests-about-mainlandshoppers-reveal-graver-problems-aisles-apart (describing Hong Kong locals' displeasure with influx of mainland visitors thronging to purchase staples and other goods, who are identified as strangers, even though many Hong Kong residents themselves were "mainlanders" migrating to the island in the $20^{\text {th }}$ Century).

251 Worship centers in the 21st Century increasingly are becoming Sharing Enterprises, especially those with strong congregant convictions about "community mission." Operations include pocket shelters, feeding and clothing the disadvantaged, and numerous on-campus gatherings of the congregation, area service organizations, and day-care activities. Once a quiet place for small gatherings, worship centers increasingly are dynamic and engaged with their surrounding communities. See, e.g., Christianity and Its Major Branches, in RELIGION AND POLITICS In AMERICA: FAITH, CUlture And Strategic Choices 71 (Robert Booth Fowler, Allen D. Hertzke, Laura R. Olson \& Kevin R. Den Dulk eds., 2010).

${ }_{252}$ This illustration is not class-war driven; I regard home-based hair salons featured in wealthy residential enclaves to be equally objectionable because of hosted parties that generate traffic. See Nancy Keates, Latest Style: Home Hair Salons, WaLl ST. J. (Jan. 15, 2015, 11:56 AM), http://www.wsj.com/articles/latest-style-home-hairsalons-1421340965. As these residence "parlors" rarely have a live-in stylist, salon 
this permit application, one expects a number of stipulations proposed by the District's residential-dwelling representatives and imposed by the hearing officer.

D. Incompatible due to saturation, where the District has reached its maximum capacity to absorb additional Sharing Enterprises. Under these conditions, a zoning permit may be granted but a city business license may be withheld until additional capacity is created by closure of another sharing producer's business in the District. Without such saturation limits, well-armed Districts may seek to move sharing producers to another district; a "saturation limit," on the other hand, creates an objective standard that must be exceeded before justifying recommending denial of every application based in the now-saturated District.

E. Compatible: An application for a sharing producer's use will be approved subject to reasonable stipulations on hours of operation, maximum on-site capacity of consumers, and other elements addressing minor public health and safety concerns.

V. “AbSOlute” Land Use DeRegulation of THe SHARING ECONOMY

"[T] he legal rules should not target the businesses themselves, but rather their potential for generating negative externalities. In other words, the ground rules should permit people to work at home so long as they do not unduly disrupt their neighbors by doing so." 253

Professor Garnett's argument above resonates across the sharing economy's intersection with land use regulation. Prior to the December 2007-June 2009 national recession ${ }^{254}$ (and the slow-recovery

activity in a majestic home no more constitutes a "home occupation" under zoning ordinances than food-sharing enterprises do in more modest dwellings.

${ }^{253}$ Garnett, supra note 70, at 1240. This fifteen-year-old (2001) paper contains a number of prescient observations addressing current sharing-economy accommodation dilemmas, among them:

An economic downturn resulting in new rounds of layoffs could wreak havoc on individuals who only recently exited welfare rolls and may be barred forever from returning .... Home businesses might offer a partial buffer against these economic realities, leading some [officials] to consider the option of increasing opportunities to work at home as an economic development tool. ... [ [T] he preference in many zoning codes for professional rather than commercial [home] occupations works to the detriment of "techie" companies. . . . Few of these companies would qualify as "professional" occupations, and many would require the would-be entrepreneur to produce or sell goods or services. See id. at 1216-17, 1222.

254 See Press Release, National Bureau of Economic Research (Sept. 20, 2010), available at http://www.nber.org/cycles/sept2010.pdf (commenting that the eighteen-month American recession was the longest since World War II). 
aftermath), her 2001 observations pertained to smaller-scale, lower revenue-number commercial businesses. Professor Garnett suggested four better land governance alternatives to wholesale prohibition, the first being that residents presumptively could operate home occupations, with local government regulation confined to punishing abusers of that privilege, perhaps through a quasi-nuisance administrative adjudicatory process. ${ }^{255}$ Professor Garnett's second suggested approach would allow smaller home businesses as a matter of right, but require some form of zoning adjustment for "major" home operations. ${ }^{256}$ A third option adapts "performance zoning" principles, under which business operators satisfy development criteria in advance of their openings and thereby present evidence that neighborhood disruptions or visible alterations of the neighborhood landscape will be non-existent or minimal. ${ }^{257}$ A fourth alternative allows neighborhoods to rely on recorded restrictive covenants binding on the land to prohibit such home businesses, a private check on local government processes, altogether ending the zoning authorities' business of regulating home occupations. ${ }^{258}$ This last alternative aids only solidly residential subdivisions with a long continuity of existence and centralized management that have not

255 See Garnett, supra note 70, at 1243 . The infirmity in this system, of course, is that the complainant in many instances would be the immediate neighbor, so that the fabric of the neighborhood is disrupted by interminable neighbor versus neighbor contests over power to prescribe behavior. This appears to be San Francisco's attitude in respect to its Short-Term Residential Rentals Ordinance, According to Mayor Edwin Lee: "With this balanced, responsible ordinance in place, San Francisco residents can share their homes and we can enforce against bad actors to protect the public." Mayor Lee Signs Legislation to Regulate Short-Term Residential Rentals In San Francisco, S.F. OfFICE OF THE MAYOR (Oct. 27, 2014), http://sfmayor.org/index. aspx? recordid $=691 \&$ page $=846$.

256 See Garnett, supra note 70 , at 1242 . The art here is to determine the boundary between "minor" and "major" home-based businesses. Is it based upon square footage of the business activity's occupancy, the number of employees "in residence," the volume of local streets' vehicular traffic (including, one imagines, bicycle and skateboard traffic) generated by the business, the amount of utilities consumed, the noise level (apart from traffic sounds), or inherent dangers arising from the Sharing Economy? Indeed, Professor Garnett's major-minor dichotomy underpins somewhat this author's "compatibility categories." See supra Part IV.C.

257 See Garnett, supra note 70, at 1242-43. In truth, this alternative is similar in kind to zoning adjustments' operation in many communities, where special exceptions (or use permits) are issued only when the applicant demonstrates a lack of material adverse impacts on the surrounding neighborhood, including minimal generation of residential vehicle or pedestrian traffic, or of noise, dust, odors, glare, fumes, vibration, and so on. See Rathkopf, supra note 175 , at $\$ 14.30$. This model seems to entail the business operator's periodic recertification of standards compliance conducted by a third-party private standards organization. See Part VI infra.

${ }_{258}$ See Garnett, supra note 70, at 1234-35. 
abandoned their original residential characters.

Ultimately one asks whether any actors, public or private, should regulate land use, instead ceding this prerogative to the "wisdom of crowds" in Districts where Sharing Enterprises seek to reside. Are "crowds" sufficiently reliable and robust within their individual enclaves to regulate Sharing Enterprises? Perhaps it is axiomatic that complex systems require the inputs of great numbers because their collective insights are superior to those from handfuls of experts because of the diversity and breadth of experiences of the masses. ${ }^{259}$ Some argue, for instance, that the safety benefit of passenger authentication in car-sharing arose not because of official perceptions but instead from entrepreneurs creating shared vehicular-use business models. ${ }^{260}$ Crowds tend collectively to have more consequential knowledge than the smartest small cadre of experts; ${ }^{261}$ and crowdsourcing is useful in the solution of certain problems such as navigating traffic jams and aiding disabled motorists in real time, such as is intended by Waze, Inc. ${ }^{262}$ Twitter Inc. and IBM have announced that the latter will have access to the full public stream of tweets back to Twitter's foundation to develop new applications and services based on their information and to offer specific industries access to packets of data generated by this agglomerated data. ${ }^{263}$

Crowds, however, tend not to organize and condense what they know into usable packets of data and information. Crowds also have

259 See Vivek Wadhwa, When Experts Are a Waste of Money, WALl ST. J. ThE ACCELERATORS BlOG (Oct. 27, 2014, 12:10 PM), http://blogs.wsj.com/accelerators/ tag/vivek-wadhwa/. See also Greg Brown, Engaging the Wisdom of Crowds and Public Judgement for Land Use Planning using Public Participation Geographic Information Systems, 52 Australian Planner 1, 2 (2015), available at http://www.landscapemap2.org/ publications/australian_planner_wisdom.pdf. Brown sagely points out the sharp distinction among mere crowd inputs, the "wisdom of crowds" (where collective opinion generates superior solutions to a problem than should one individual) and "public judgement," where the collaborative product is high quality opinion that is "firm, consistent, and mindful of consequences." See id. at 3-4.

260 See Charley Moore, Why Ride Sharing Regulators Should "Tread Lightly, "LINKEDIN PulSE (Sept. 5, 2013) https://www.linkedin.com/pulse/20130905223920-1523803why-ride-sharing-regulators-should-tread-lightly.

261 See SOWELL, supra note 126, at 16-17.

262 Waze urges participation by "millions of drivers out on the roads, working together towards a common goal: to outsmart traffic and get everyone the best route to work and back, every day." "Wazers" who edit and update maps on the Web interface are rewarded with more points than those who merely are consumers. See WAZE, https://www.waze.com/ (last visited Sept. 12, 2015).

263 See Don Clark \& Yoree Koh, Twitter, IBM to Harness Tweet Data for Business, WALL ST. J., Oct. 29, 2014, at B6, available at http://online.wsj.com/articles/ibm-and-twitterforge-partnership-on-data-analytics-1414601963?. 
the habit of trending ${ }^{264}$ instead of seeing a larger picture or engaging in "second-stage" thinking (anticipating ramifications of implementing one course of action). ${ }^{265}$ Trending, and reversing course, may be inefficient to the point of imposing an unacceptable cost. ${ }^{266}$ Furthermore, trending can be manipulated, even distorted, by technology masters, like schooling fish being re-directed by a "cyberfish." ${ }^{267}$ Communities must consider whether technology can be applied even-handedly to analyze and process the "wisdom of crowds" where land-planning is concerned, and exactly whose wisdom is relevant. ${ }^{268}$ Should inputs from the portion of the crowd living farther from the applicant Sharing Enterprise carry equal weight to the crowd segment living and working adjacent to the sharing producer's business? If not, how is the pertinent "crowd" identified for any

264 Indeed, "trending" is a darling of media outlets believing it relevant (and hip) to report on the latest trends. ABC News' evening broadcast emphasizes a "trending now" segment, for example. See ABC NEws, www.abcnews.go.com/ (last visited Sept. $12,2015)$. The point of Twitter "tweet" analytics is to discover regurgitated common denominators of breaking news and commentary, otherwise known as "trending topics" or "buzz." See Analytics, TwITTER, https://analytics.twitter.com/ (last visited Sept. 12, 2015).

See Thomas Sowell, Applied Economics: Thinking Beyond Stage One, 5-7 (2009).

${ }^{266}$ See Anindya Ghose, Build a Relationship with People in the 'Crowd, 'WALL ST. J. THE ACCELERATORS, Oct. 30, 2014, at B5 ("A very high volume of half-baked ideas brings with it the overhead cost of evaluating those ideas . . . when ideas aren't completely thought-through, they simply create a lot more work for the organization.").

${ }^{267}$ See, e.g., $B B C$ Trending: Manipulating the Internet, BBC, http:/ /www.bbc.co.uk/programmes/p01ndgys (last visited Sept. 12, 2015) (reporting fake identities to artificially create trends or boost "follower" numbers exploiting software routines called "bots"); Alok Shukla, Social Media Manipulation Is for Real, Some Call It as Crowd-Turfing!, MCAFEe BlOG Central (Dec. 2, 2013), https://blogs.mcafee.com/consumer/social-media-manipulation-is-for-real-somecall-it-as-crowd-turfing (describing methods of manipulating social media through automated and manual approaches that are prevalent in many countries such as the United States and China). See also John Drury et al., Transforming the Boundaries of Collective Identity: From the 'Local' Anti-Road Campaign to 'Global' Resistance? 2 SocIAL MOVEMENT STUDIES 191-212 (2003) (discussing that collective action becomes possible when a particular social identity is simultaneously salient and therefore shared among crowd participants).

268 See Brown, supra note 259, at 9 ("[T] here is an assumption that making good decisions is about finding the right person or persons with the answer . . . many land use decisions involve social value decisions that are framed as technical decisions where experts offer no special insight into social values beyond the capacity of the crowd itself."). Perhaps an answer to this dilemma of manipulation will be accelerated in America by governments' sharing data gathered with the general public, an initiative of the Obama Administration under Making Open and Machine Readable the New Default for Government Information, its Open Data Policy. See Exec. Order No. 13,642, 78 Fed. Reg. 28111 (May 9, 2013), available at http://www.gpo.gov/fdsys/ pkg/DCPD-201300318/content-detail.html. 
prospective Sharing Enterprise? ${ }^{269}$ The democracy element of "crowd wisdom" must be viewed through the lens of possible distortion of data mined using technology.

Houston, Texas is the over-cited illustration of the virtue of eliminating land use regulation. ${ }^{270}$ Despite its putative lack of zoning, Houston is not the venue for a land-development free-for-all. ${ }^{271}$ Development in Houston is regulated through three different processes. ${ }^{272}$ The city regulates development through an approval process that focuses mainly on the impact of land development on public services. ${ }^{273}$ New developments, for example, must conform to performance criteria for public services such as sewer and road capacity. ${ }^{274}$ A second regulatory mechanism is private restrictions on land use adopted through legally enforceable land covenants, or voluntary restrictions on future land uses by current property owners. ${ }^{275}$ Real covenants can (and often do) exclude specific uses, such as commercial enterprises or businesses. ${ }^{276}$ Still, a surprising number of parcels are "unrestricted," particularly in established neighborhoods of the city, enabling informal market forces, the third "governance"

269 In zoning adjustment public hearings, the author frequently asks advocates and opponents about their respective residential distances from the application's site and rarely is surprised by the smaller numbers of speakers genuinely affected immediately by the proposed use in the slightest manner; after all, it is a public hearing.

270 See, e.g., Alan Ehrenhalt, The Great Inversion and the Future of the American City 170-74 (2013); Bernard H. Siegan, Non-Zoning in Houston, 13 J. L. \& ECON. 71, 75 (1970).

${ }^{271}$ See Samuel R. Staley, The Progressive Roots of Zoning, THE FreEman BLOG (Mar. 28, 2012), http:/ / fee.org/freeman/detail/the-progressive-roots-of-zoning.

Id.

273 Id. The Houston Planning Commission, which includes citizens, elected officials, and the Director of Planning and Development, reviews and approves subdivision and development plats. The Commission also studies and makes recommendations to City Council on development issues in Houston. See Planning Commission, CITY OF HOuSTON, http://www.houstontx.gov/planning/ Commissions/Planning-Commission (last visited Aug. 5, 2015). Finally, Houston's City Ordinance enumerates and penalizes public nuisances. See Hous., Tex., Code of ORDINANCES, \& 10-451 (1985), available at https://library.municode.com/ index.aspx?clientId=10123\&stateId=43\&stateName=Texas.

274 See Staley, supra note 271. Houston's development is governed by codes that address how property can be subdivided, while site plans are checked for compliance with city regulations that include off-street parking, tree and shrub requirements, setbacks and access. See Planning and Development: Development Ordinances, CITY OF Houston, http://www.houstontx.gov/planning/DevelopRegs/dev_ord.html (last visited Aug. 5, 2015).

275 See Staley, supra note 271.

276 See, e.g., Georgette Chapman Phillips, Boundaries of Exclusion, 72 Mo. L. REv. 1287, 1302 (2007) (explaining that deed restrictions insure expectations of exclusion are met). 
mechanism, to regulate dimensions of timing, intensity and place of development. ${ }^{277}$

Through Euclidean zoning regulation avoidance, Houston dramatically speeds up the approval process while enabling the land market's effective response to economic trends. ${ }^{278}$ Under conventional zoning regimes, securing rezoning for a major project can take years. In Houston, substantial developments, such as multifamily housing projects, are approved through its performance-approval system and are fully constructed within a year. ${ }^{279}$ Houston's market-oriented approach to land use has also allowed it to adapt, building multiple employment centers to accommodate new economic challenges and opportunities. ${ }^{280}$ While Houston was not immune to the recessionary housing market collapse, its housing market was more resilient and adaptable to changing circumstances. ${ }^{281}$

While that convention seems enticing, Houston's laxer land use regulatory methods have their critics. ${ }^{282}$ Its government asserts some types of control as part of its police power and its trust relationship to its citizens; as a result, certain projects can be delayed or stymied altogether. But a city does not need to shed all zoning regimes to inject sharing producers into neighborhoods. Fundamentally, what sharing producers need in order to work side by side with dwellers in residential neighborhoods are these few essential elements:

a. Low barriers to "entry" into new sharing spaces, such as the opportunity to work from home (combining family management with entrepreneurial activities) so long as interference with the lives of other neighbors is not material;

b. Proximity of other informal economy business spaces (because innovation occurs in physical clustering, as has been demonstrated time and again ${ }^{283}$ ), such as by allowing the

277 See Staley, supra note 271. But see Teddy M. Kapur, Land Use Regulation in Houston Contradicts the City's Free Market Reputation, 34 ENVTL. L. REP. 10045, 10051, 10061-62 (2004), available at http://www.pszjlaw.com/media/publication/427_Kapur\%20\%20ELR\%20land\%20use\%20regulation.pdf (discussing that, although perhaps threefourths of its land mass has no deed restrictions. Houston is not a good example of a free market for land use, as its government routinely intervenes in land use decisions).

278 See EHRENHALt, supra note 270, at 172-73; Staley, supra note 271.

279 See EHRENHALt, supra note 270, at 172-73; Staley, supra note 271.

280 See EHRENHALT, supra note 270, at 170; Staley, supra note 271.

281 See EHRENHALT, supra note 270, at 172-73; Staley, supra note 271.

282 See, e.g., EHRENHALT, supra note 270 , at 175-78 (discussing the resulting autocentric dependency and sprawl); Michael Lewyn, How Overregulation Creates Sprawl (Even in a City Without Zoning), 50 WAYNE L. REv. 1171, 1177-92 (2005) (explaining that Houston has broken from "laissez-faire" development policies).

${ }^{283}$ See, e.g., Bruce Katz \& Julie Wagner, The Rise of Innovation Districts: A New 
repurposing of unused or underutilized buildings for "maker spaces"; ${ }^{284}$

c. Allowing street curbside parking for customers, delivery service personnel and sharing entrepreneurs' work without enabling local traffic to become gridlocked;

d. Flexible sign regulation for less obtrusive and standardized building-exterior business identification plaques like $\mathrm{QR}$ Codes; and

e. A credible punishment scheme for “defectors," niche enterprise does not endure additional costs free-riders escape paying, or endure the "guilt by association" with those sharing producers regularly defecting from District norms.

\section{The Future of Private Regulation OF SHARING ENTERPRISES}

Thoughtful sharing economy advocates seeking accommodation with neighborhood dwellers should promote new types of selfregulatory organizations setting and enforcing basic regulations for peer-to-peer sharing marketplaces and platforms, ${ }^{286}$ while collaborating with public agencies on government oversight of regulation enforcement. ${ }^{287}$ One such means is private certification,

Geography of Innovation in America, The Brookings Inst. 2, 4-5, 9, 12 (May 2014), http://www.brookings.edu/ /media/Programs/metro/Images/Innovation/Innovat ionDistricts1.pdf. Such districts address three of the main challenges of our time: "[a] sluggish growth, national austerity and local fiscal challenges, [b] rising social inequality, and [c] extensive sprawl and continued environmental degradation"; and many districts are close to low- and moderate-income neighborhoods. Id. at 2. Further, such districts impact neighborhoods by creating new public spaces and activating streets to draw people together, incidentally re-designing corridors to make them more pedestrian-friendly. $I d$. at 17.

284 To incorporate "third spaces" as part of each new local development, entrepreneurial incubators that transition sharing producers with "scalable" business models to commercial offices or commerce park spaces outside the residential neighborhood accomplishes two goals: maintaining residential character and accelerating the sharing producer's model. Most Districts have vacant buildings where adaptive reuse presents the opportunity to make space available affordably to entrepreneurs. See Widener, Tactical Urbanism, supra note 109.

${ }^{285}$ See Schoenmakers, supra note 154, at 36 (explaining that "pool" or central institutions' sanctions can create a sufficiently strong selective pressure to prevent cheating; and these institutions' mere existence and visibility has some deterrent effect on defection). The article's authors claim that opportunists "always act as defectors in the absence of the threat of punishment in the form of an effective sanctioning system," but become cooperators when the sanctioning institution, a "public signal," is supported by others who are stakeholders. See id. at 11-12.

${ }_{286}$ See Cohen \& Sundararajan, supra note 81, at 126-28.

287 See Sundararajan, supra note 130 (observing that industry consortiums for selfpolicing could inform emerging oversight questions as Sharing Enterprises achieve scale, such as "whether residential zoning and noise laws should change when 
where private entities assure that the products or the services they certify meet criteria specified by the proper professional associations, recognized standards-setting organizations and government agencies. ${ }^{288}$

Sharing producers have superior knowledge of their means and methods of producing goods and services. This superior knowledge is vastly more than the knowledge of surrounding residents or of local administrators who regulate land use, many of whom may view the operations of Sharing Enterprises with suspicion or alarm. Logic initially supports the idea of the sharing producers' self-regulation, to the extent they demonstrate capacity to implement standards earnestly (including by incorporating inputs from District Councils) and comprehensively. Private standards-setting has substantial history and credibility. Consumers rely on private certification when purchasing goods and services, while companies rely on such standardsconfirmation when choosing suppliers. ${ }^{289}$ Likewise, some government agencies use certification to gauge regulatory compliance. ${ }^{290}$ Private industry self-regulation is advantageous in responding to a market failure or addressing novel, unanticipated consequences of new levels of interdependence created by complex technologies and globalization unfamiliar to traditional government operations. ${ }^{291}$ Business has much to gain from self-regulation when the reputation of an industry sector or profession is at stake $;^{292}$ this is the historical reason for undertaking private standards-setting.

Reliable private certification addresses the market's appetite for certification $^{293}$ without yielding to competitive pressures to "cut

individual apartments become mixed-use real estate"). See also Cohen \& Sundararajan, supra note 81, at 131 (arguing the need for governmental oversight). Of course, the neighbors might seek to resolve such issues prior to a building's conversion to incorporate fully mixed-use business models. See also Lawrence J. Lad \& Craig B. Caldwell, Collaborative Standards, Voluntary Codes and Industry Self-regulation, 35 J. CORP. CitiZENSHIP 67, 69, 71 (2009). In the case of land use regulation, the government must serve as the enforcer of last resort. See supra text accompanying notes 169-77. Additionally, collaboration overcomes most antitrust claims potentially arising from alleged restraint of trade. See Lad \& Caldwell, supra note 287, at 71.

${ }_{288}$ See Lad \& Caldwell, supra note 287, at 71. See also Timothy D. Lytton, Competitive Third-Party Regulation: How Private Certification Can Overcome Constraints That Frustrate Government Regulation, 15 THEORETICAL INQUIRIES IN LAW. 539, 540 (2014).

289 See Lytton, supra note 287.

290 See id.; Miller, supra note 1 (noting that licensure enables collecting information on licensees as well as being a means of regulating scofflaws).

291 See Lad \& Caldwell, supra note 287, at 68.

$292 \quad$ See id. at 70.

293 Lytton, supra note 288, at 540. 
corners. ${ }^{294}$ Fire safety certification by Underwriters Laboratories (UL) of more than 20,000 different types of products made by 69,000 manufacturers $^{295}$ and the Product Safety Code implementation process under the Responsible Care Guiding Principles adopted by the American Chemistry Council ${ }^{296}$ illustrate two types of private standardssetting and enforcement. ${ }^{297}$ Properly functioning reliable private certification compares favorably to government regulation because the former applies greater technical expertise. ${ }^{298}$ Indeed, many public regulators rely on private standards to give their regulations more credibility; often, government regulations incorporate a privateindustry standard by reference. ${ }^{299}$

Private certification provides superior inspection and monitoring coverage of regulated entities when inspection and monitoring strain public agency budgets. ${ }^{300}$ For private certifiers, inspection and monitoring actions generate fees. ${ }^{301}$ "The income received from inspection services prompts UL to inspect facilities at least four times per year," far more frequently than most government agencies can afford. $^{302}$ Certification is often more efficient than government regulation. Because private certifiers are motivated to regulate partially by industry demand, they are less likely than government regulators to develop cost-inefficient standards where costs outweigh the standards' benefit to consumers. Additionally, private certification is often more proactive and prospective than government regulation. ${ }^{303}$ Private product-safety certifiers typically anticipate problems and revise standards in light of industry group experience; ${ }^{304}$ in contrast, government regulators generally await demand for responsive rule-

294 Id. at 541.

295 Id at 545-53.

296 See Responsible Care Product Safety Code, AMERICAN CHEMISTRY Council, http://responsiblecare.americanchemistry.com/Responsible-Care-ProgramElements/Product-Safety-Code (last visited Sept. 12, 2015).

297 Cohen and Sundararajan would refer to these as SROs, distinguishing them from trade organizations seeking to promote their industries' well-being. An SRO, by contrast, polices an industry "by formulating regimes of collective rulemaking in which entities come together to develop, monitor, and, at times, enforce standards to govern the behavior of members." Cohen \& Sundararajan, supra note 81, at 124.

298 See Lytton, supra note 288, at 543, 545.

299 Id. at 564. To be sure, governments grant tacit approval to this process when electing to have the private sector set standards on its own. See Lad \& Caldwell, supra note 287 , at 76 .

300 See Lytton, supra note 288, at 564.

$301 \quad I d$. at 564.

302 Id.

$303 \quad I d$. at 565.

304 See id. at 565-66. 
making.

Private certification may complement or compete with government regulation. ${ }^{305}$ The relationship between them may change over time. ${ }^{306}$ In matters of regulatory design, the important question may be how to most effectively combine these pathways to establish a problem-solving relationship in place of adversarial relations between small business and government. ${ }^{307}$ One solution in the land use realm may be to give sharing producers the election to comply with specific public regulations in the municipal zoning code (subject to periodic compliance inspections) or obtain certification from a private, industry-sponsored agency (with periodic renewals). The latter option permits confirming sharing producers meet or exceed industry certification standards (including providing sufficient floor area to accommodate employees, ample parking and delivery vehicle access points to their places of business, fire and plumbing safety and sanitation of internal operations, proper insurance coverage of building and other improvements, and compliant business exterior identification $^{308}$ ) for operating their particular Sharing Enterprise. Since industry certification standards can be tailored to address the particular circumstances of a business type, the majority of sharing entrepreneurs may prefer complying with particularized land-useoriented rules for their models of business operations. This particularly is true as the number of Sharing Enterprise types increases. ${ }^{309}$

Perhaps "therein lies the rub." 310 The current (and likely future) challenge for self-regulation is structural. Few organized "trade groups" exist among sharing producers, even while a few form

$305 \quad$ Id. at 542.

306 Lytton, supra note 288, at 542.

307 See Lad \& Caldwell, supra note 287, at 73.

308 Of course, these standards cannot conflict with the community's zoning standards, thereby avoiding controversy over the proper means that meet mutually agreed-upon ends of land use regulation, in the process reframing the standards as a form of collaborative control. See Lad \& Caldwell, supra note 287, at 78.

309 Likely no one can calculate how many sharing producers exist today. The reason references to "shadow economy" and "underground economy" exist in popular parlance is that many such businesses are not self-identifying, to avoid taxation and other regulatory costs. See Cash Intensive Businesses Audit Techniques Guide-Chapter 8 The Underground Economy, InTERnAL REVEnUE SERvice (Apr. 2010), http:/ / www.irs.gov/Businesses/Small-Businesses-\&-Self-Employed/Cash-IntensiveBusinesses-Audit-Techniques-Guide-Chapter-8; Brad Plumer, The \$2 Trillion Shadow Economy Is the Recession's Big Winner, Wash. Post WonkBlog (Apr. 23, 2013), http://www.washingtonpost.com/blogs/wonkblog/wp/2013/04/23/americas-2trillion-shadow-economy-is-the-recessions-big-winner/.

310 William SHAKESPEARE, HAMLET act 3, sc. 2. 
communities of interest on the Web. ${ }^{311}$ The rapid rate of this new economy's innovation outstrips the capacity to organize formal trade groups like Underwriters Laboratories; and some sharing producers have scant experience, time or other resources, or the disposition, to form voluntary associations charged with credentialing their "members." Indeed, those in the vanguard of Sharing Enterprises today may not represent tomorrow's sharing producers. A "sector" of enterprises may innovate so quickly, radically changing methods and outputs, that the original vanguard is unqualified to pass judgment on the quality, safety or other standards of scantly-later entrants into a similar or "mutated" sector. Since there are no convenient categorizations of today's sharing producers in terms of their outputs of goods and services, interest communities must devote substantial time and thought just to define a "sector" and determine which producers (and their outputs) may have the knowledge to regulate through standards-setting, again assuming they were disposed to set standards for others.

Additional roadblocks are apparent to short-term private certification of Sharing Enterprises. First, citizens unacquainted with third-party private associations will not know how to report standards slippage by a sharing producer operating in their enclaves. ${ }^{312}$ While Sharing Enterprises may disclose on their building-exterior tags

311 In March 2015, a new trade body for the sharing economy, Sharing Economy UK (SEUK), was launched to represent and champion the sharing producer sector and ensure good business practices; its members include Airbnb, TaskRabbit and Zipcar. See Susan McLean, The Rise of the Sharing Economy, 26 COMPUTERS \& LAW MAGAZINE OF SCL 1 (Apr./May 2015), available at http://www.mofo.com/ / media/Files/Articles/2015/04/150401RiseoftheSharingEconomy.pdf. Peers.org is a self-described "grassroots organization" launched in 2013 in Silicon Valley to "mainstream, protect, and grow the sharing economy" by advocating for "smart regulations." See About, PEERS, http://www.peers.org/about/ (last visited Sept. 12, 2015); Tarun Wadhwa, The Sharing Economy Fights Back Against Regulators, FORBES (Sept. 16, 2013, 7:02 AM), http://www.forbes.com/ sites/tarunwadhwa/2013/09/16/thesharing-economy-fights-back-against-regulators-with-an-advocacy-group/ ("Peers is a self-described 'grassroots organization' that launched last month to 'mainstream, protect, and grow the sharing economy."'). But reports are that Peers.org's funding comes from "mission-aligned independent donors," wealthy backers with a financial interest in the advance of the sharing economy. In late 2014, Peers announced it would re-direct its emphasis toward sharing economy workers. See Sarah Kessler, Peers Says Its New Focus Is Helping Sharing Economy Workers, FAStComPAnY TECHNOLOGY (Nov. 12, 2014, 6:00 AM), http://www.fastcompany.com/3038310/peers-says-its-new-focusis-helping-sharing-economy-workers.

312 Nor will they have intimate knowledge of the standards themselves, unless the resident is a member of the affected or similar Sharing Enterprise interest community. Of course, the "where to report a complaint" dilemma may be resolved by requiring that information to be posted on the platform of the Sharing Enterprise's marketing technology. 
contact information for the pertinent certifying body, not all residents have the technological devices to "read" that information. In contrast, most citizens know how to telephone or email their community's government. Second, with a variety of "sector" standards, there is a clear danger of apparently inconsistent sanctions among trade groups of miscreant sharing producers. This may undermine both producer and citizen confidence in the private certification process and would likely promote defections among sharing producers from established norms. Third, it is unclear that the opportunity to be privately regulated is sufficient inducement for Sharing Enterprise participation in certification or oversight functions.

There is much to contemplate among all stakeholder groups in outsourcing such regulation to private bodies, even for those believing that entrepreneurs can best govern themselves, in opposition to historically reactive local governments. Regardless, government agencies ensuring land use compliance still must monitor activities of certifying bodies in the appropriate Sharing Enterprise sectors. ${ }^{313}$ Private certification is not invariably reliable, and market competition among certifiers sometimes results in diminished standards to reduce costs of services and ease demands placed on clients. ${ }^{314}$ Enforcement of zoning entitlements in any event will remain the job of local governments. A pragmatic reason here is that a community ultimately may be subject to claims of "regulatory taking" if private certification sanctions incorporate closure of a Sharing Enterprise for violating de facto land use regulations. Moreover, mere approval of a Sharing Enterprise's operation by a contracted private body over objections of a District's citizens may engender claims of due process denial since a private entity's performance of a public service may escape constitutional restraints. ${ }^{315}$

313 Legally, land use regulation enforcement cannot be delegated altogether to private bodies. See supra text accompanying notes 170-74. Additionally, government may (in the background) threaten more severe regulation should self-regulation processes not achieve the intended ends. See Lad \& Caldwell, supra note 287, at 75.

314 Lytton, supra note 288, at 541.

315 See Jackson v. Metro. Edison Co., 419 U.S. 345, 373 (1974) (Marshall, J., dissenting); Shirley L. Mays, Privatization of Municipal Services, A Contagion in the Body Politic, 34 DuQ. L. REv. 41, 53-55 (1995). 


\section{CONCLUSION}

Sharing producers are a part of the urban and suburban economic landscapes and intend to remain so. Perhaps "New Cities Scientists" hope that young entrepreneurs will be well-trained and sufficiently imaginative to invent new business models that will be jobsgenerators and will populate transit-oriented, densely built, mixed-use developments (so-called TOD zones) in municipal commercial cores or along mass transit corridors. Positioned there, issues of neighborhood conflict among sharing producers, town planners and dwellers perhaps will diminish to the point of easy resolution by a single city department tasked with ad hoc conflict resolution.

Cleaving this idealism are facts and anecdotal evidence, starting with an apparent shortage of youthful entrepreneurial persons eager to occupy downtowns conveniently catalyzing every urban center's renaissance. Demographer Wendell Cox reports that from 2010 to 2013, the population of twenty- to twenty-nine-year-olds in core counties (which usually are identical to the core city of the metropolitan area) rose by about $3.4 \%,{ }^{316}$ in contrast to the overall increase nationwide of $4 \%$ of that age group in that same interval. Despite the growth in raw numbers of twenty- to twenty-nine-year-olds living in core counties, the share of the age group living in these areas actually declined slightly, by $0.78 \%$, compared to $2010 .{ }^{317}$ Meanwhile, the share of the age group living in the less dense portions of metropolitan and micropolitan statistical areas increased. Overall, roughly just $30 \%$ of all Millennials live in core counties; and in the three years between 2011 and 2013, the number of Millennials outside core counties increased by 1.28 million. In 2010, functional urban cores, meaning those characterized by higher-density development and greater reliance on transit, were home to $19 \%$ of the twenty- to twenty-nine-year-olds in major metropolitan areas, a reduction from $20 \%$ in 2000. It appears that Richard Florida's expectation, that a majority of educated and theoretically committed "urbanite" Millennials will gravitate to the diverse city cores of their preference, ${ }^{318}$ is suspect- especially among those unemployed or out of the

316 See Wendell Cox, From Anecdotes to Data: Core E Suburban Growth Trends 2010 2013, NEWGEOGRAPHY (May 23, 2014), http://www.newgeography.com/ content/004329-from-anecdotes-data-core-suburban-growth-trends-2010-2013.

317 Id.

318 See Richard Florida, The Rise of the Creative Class, WASH. MONTHLY (May, 2002), http://www.washingtonmonthly.com/features/2001/0205.florida.html. Richard Florida's creativity rankings, which anchored material for many of his books, originally appear in this Article, are a good précis of the body of his works on the Millennial "Creative Class." 
workforce and living in their parents' homes. Additionally, Millennials may well be living in suburban apartments where less expensive inventory is readily available $;^{319}$ while others at the oldest margin of this generation may be starting families and buying houses, migrating instead to the suburbs and smaller cities.$^{320}$

According to survey data from Frank N. Magid Associates, young Millennials already reside in the suburbs to at least the same extent as older generations. ${ }^{321}$ The Magid data also suggests that this residential preference likely will not change as the Millennial generation matures and "settles down." Once Millennials marry, their firm preference is to live in a single-family home, ${ }^{322}$ atypical of hipster-urban settings such as lofts, condos or apartments. Almost half of "settled" Millennials (those who are married, many with children) own their homes. It appears today that community-and family-orientation of the Millennial generation will only reinforce the continued growth of America's suburbs. In the same vein, Joel Kotkin, author of The Next Hundred Million, believes that a significant majority of the forthcoming hundred million persons among Americans will make their homes in what Kotkin calls "greenurbia," the suburbs of tomorrow whose dwellers rely less on major cities' central business districts for jobs and cultural amenities, as working from home becomes customary. ${ }^{323}$ In

319 See Laura Kusisto \& Kris Hudson, Renters Are Majority in Big U.S. Cities, WALL ST. J. (Feb. 8, 2015), http://www.wsj.com/articles/renters-are-majority-in-big-u-s-cities1423432009 (noting that rents are rising in many cities and rents outpace inflation rates).

320 See April Lane, Why Millennials Are Moving to Suburbs and Smaller Cities, BENTLEY PreparedU Blog (May 21, 2015), http:/ /www.bentley.edu/prepared/why-millennialsare-moving-suburbs-and-smaller-cities.

321 See Morley Winograd \& Michael D. Hais, Millennial Momentum: How a New GENERATION IS REMAKING AMERICA 196-201, 208 (2011).

See id. at 201.

323 Joel Kotkin, The Next Hundred Million: America In 2050 85-87, 234-37 (2011). Kotkin may be beating this drum too loudly, however. In his latest piece in The Daily Beast, Kotkin stridently asserts (a) Jane Jacobs was wrong about diversity characterizing today's urban metropolis cores, and (b) the central city offers only a temporary lifestyle for all but the wealthy and childless, thus roughly three-fourths of Americans live in suburbs, especially when starting families, and will continue to do so. See Joel Kotkin, What Jane Jacobs Got Wrong About Cities, DAIly BeAST (Aug. 1, 2015, 10:00 PM), http://www.thedailybeast.com/articles/2015/08/01/what-jane-jacobsgot-wrong-about-cities.html. Kotkin's vision fails to account for (a) the rising tide of student debtors among Millennials, (b) the volatility in vehicular fuels' prices, and (c) the availability of mortgages to persons affected by these first two phenomena, coupled with underemployment, delaying marriage (compared to prior generations), and spiking rental costs impairing saving for a down-payment. In their current circumstances, youth on the workforce margins will live (and often work) where and in what they can afford, often in their relatives' abodes and in shared housing among unrelated persons (locational preferences be hanged). 
short, the notion that sharing producers will concentrate in densely urbanized pockets of cities may be illusory, while scattering throughout the metropolis may be the continuing pattern of sharing producers for some time. ${ }^{324}$

The business community, like demographic pundits, is conflicted about the shortfall in entrepreneur supply. While the Wall Street Journal reported in $2015^{325}$ resurgence in the preference to live and work downtown, it concurrently reported a decrease in the ownership of businesses by young adults struggling to find their niche in the American workplace. Richard Florida himself observes that the emerging micro-gig labor pool participants today identify more with their occupation, skills or livelihood than with an employer, in part due to what he calls "domain specific knowledge."326 Florida believes that Millennials and those generations following will define themselves by their work's creative content and their lifestyle interests instead of by their career track or institutional affiliations. ${ }^{327}$ Why, then, might most micro-business owners prefer occupying pricier downtown districts? Perhaps the current circumstances embody Florida's observation that:

[People] have come to accept that they are completely on their own-that the traditional sources of security and entitlement no longer exist, or even matter. This is a sea change .... The shift to self-motivation and personal autonomy in the workplace is bound up with the fact that we no longer take our identity from the company we work for, but find it in the kind of work we do, our profession, our lifestyle interests and the community we live in. ${ }^{328}$

${ }^{324}$ See Philip Lawton, Michal Meczynski \& Austin Barber, Policies Towards Place Attraction and Policies for Place Retention, in Place-MAKING AND POLICIES FOR CoMPETITIVE Cities 105, 110, 123 (Sako Musterd \& Zoltán Kovács eds., 2013) [hereinafter MUSTERD] (noting the "wide selection of living environments among the 'creative class' in selecting a residential area”); Marco Bontje \& Kaisa Kepsu, Creative Knowledge Strategies for Polycentric City-Regions, in Musterd, supra note 324, at 191, 192, 200 (making like observations).

${ }^{325}$ Clarifying, "the same time" literally means the same day, January 3, 2015; compare Eliot Brown, Young Drive an Urban Rebound, Wall ST. J., Jan. 3, 2015, at A3, available at http:/ /www.wsj.com/articles/young-drive-an-urban-rebound-1420250736, with Ruth Simon \& Caelainn Barr, Endangered Species: The Young Entrepreneur, WALL ST. J., Jan. 3, 2015, at A1, available at http://finance.yahoo.com/news/endangeredspecies-young-u-entrepreneurs-004800314.html.

326 Richard Florida, The Rise of THE CREATIVE Class ANd How IT'S Transforming WORK, LEISURE, COMMUNITY AND EVERYDAY LIFE 114 (2002).

${ }^{327} I d$.

Id. at $115-16$. 
In summary, the sharing entrepreneur producing goods and services without a full time job or the intention to generate work for employees is not temporary; these widely dispersed proprietors are growing by magnitudes among the working age population. ${ }^{329}$ Sharing producers are here to stay $^{330}$ and communities must learn how they will be integrated, not (conveniently) only into downtowns and other mixed-use centers but throughout the general population in small cities and villages ${ }^{331}$ —and even in semi-rural areas. Such a role will not be easy to discharge. Middle or upper class populations' resistance to reusing residentially-zoned property for new models of occupancy entrenches support for existing zoning patterns. ${ }^{332}$ Historically, zoning

329 Derivative start-ups, where new entrants to the sharing economy "piggyback" on the success of a growing business model, will accelerate in numbers, increasing the growth potential of all Sharing Enterprises. See Charlie Wells, "Piggybackers" Hitch Themselves to Airbnb, Uber, Wall ST. J. SMAll Business, Feb. 19, 2015, at B5, available at http://www.wsj.com/articles/piggybackers-hitch-themselves-to-airbnb-uber-

1424305849 ? $\bmod =\mathrm{LS} 1$. A plausible analogy is to the supply chain in the automobile industry with "tiered" parts suppliers.

330 The single data point known as the "labor force participation rate" proves this proposition. That term refers collectively to adults who are working or currently seeking work. See Definition of Labor Force Participation Rate, Dave Manuel.Com, http:/ / www.davemanuel.com/investor-dictionary/labor-force-participation-rate/ (last visited Aug. 2, 2015). In June 2015, the American labor force, using raw jobs numbers, grew by about 223,000 workers. See Gandel, supra note 43 . That increase effectively dropped the labor force participation rate to a tepid $62.6 \%$ of the workingage population, the lowest that rate has been since 1977. Id. The decline in the participation rate accelerated in recent years in large part because many Americans gave up searching for conventional forty-hour-per-week jobs. Id. And employed young Americans are not earning higher wages in these new jobs. Id. These figures do not mean, however, that younger workers have abandoned pursuing financial selfsufficiency. Those who cannot earn sufficient wages to be independent will seek alternatives to reach their desired standard of living. While one alternative may be "the dole," another option for those more educated, capable of accessing the implements of technology, may be to exploit social media and engage in one or multiple Sharing Enterprise opportunities.

${ }_{331}$ See generally Kris Hudson, Generation Y Prefers Suburban Home Over City Condo, WALL ST. J., Jan. 22, 2015, at A2, available at http://www.wsj.com/articles/millennialsprefer-single-family-homes-in-the-suburbs-1421896797? tesla $=y \& a u t o l o g i n=y$

(discussing that the overwhelming majority of Millennials' preference to reside in inner-city suburbs may alter future demand for single-family homes); Neil Shah, Signs of a Suburban Comeback, WALL ST. J. (May 22, 2014), http://www.wsj.com/ news/articles/SB10001424052702303749904579576440578771478?mg=reno64-wsj (suggesting that the "bottoming out" of city growth may signify a resurgence of suburban living). Alan Ehrenhalt sees, in the desire for an urban-seeking cohort of Millennials, a possible trend to "urbanize the suburbs," building new fulcrums of activity by densifying suburban "retrofits." See EHRENHALT, supra note 270, at 208-17.

${ }^{332}$ See supra text accompanying notes 209 \& 210; cf. Simon Vallee, Zoning's SelfDefense Mechanism: When Local Democracy Is Local Tyranny, URBAN KCHOZE BLOG (Apr. 29, 2014, 1:10 AM), http://urbankchoze.blogspot.com/2014/04/zonings-self-defensemechanism-when.html (arguing that attempts to change zoning are better submitted 
has been calculated in residential districts to establish homogeneous neighborhoods; thus, inserting a new sharing producer business model either requires a change in the property's zoning category or some form of zoning adjustment. Non-residents typically have little voice in this discussion, since modifying a zoning map to introduce new types of housing occupancy benefits only non-residents (i.e., potential future occupants). "Local-only democracy" customs further ensure that any entitlement proposed to introduce a new use engages few, if any, local supporters. ${ }^{333}$ Meanwhile, as local (incumbent) residents seemingly will not benefit directly from the entitlement proposal, these residents form either (i) an opponents' group (among those for whom the proposed zoning modification is potentially or actually disadvantageous) or (ii) a disinterested group (whose members do not share the opponents' views or are simply apathetic) ${ }^{334}$

The opponents' group often becomes strident, or even irrational, about the proposed modification ${ }^{335}$ (unless they become better informed) fearing change in the familiar but segregated, homogeneous neighborhoods they occupy. In any case, those loudest voices in the debate invariably oppose the initiative, as proponents usually are not current residents and therefore are not "invested" in the District. ${ }^{336}$ Even if opponents constitute a minority of all District dwellers, since its real majority more often than not is disinterested, opponents may stymie the initiative, essentially exercising "veto power." 337 This inclination has exceptions, such as in conditions where neighbors are poor and lack influence but are facing politically influential developers who want a zoning change, or where project leaders induce local residents to drop their opposition through the

through local democracy because local residents have input (albeit perhaps more in theory than in practice) on whether zoning changes are made). In the current climate, "battle lines" are drawn in some neighborhoods between those who "value stability more than flexibility: middle-aged professionals with children to educate and mortgages to pay," versus "people who value flexibility more than security: students who want to supplement their incomes; bohemians who can afford to dip in and out of the labour market; young mothers who want to combine bringing up children with part-time jobs; the semi-retired, whether voluntarily so or not." Irving Wladlawsky Berger, The Rise of the On-Demand Economy, WALl ST. J. CIO Journal (Mar. 13, 2015, 12:04 PM), http://blogs.wsj.com/cio/2015/03/13/the-rise-of-the-on-demandeconomy/.

333 See Vallee, supra note 332.

334 See id.

335 See John R. Nolon, Champions of Change: Reinventing Democracy Through Land Law Reform, 30 HARV. ENVTL L. REV. 1, 16 (2006) (noting the "instinctive, rather than thoughtful, reaction").

See Vallee, supra note 332.

337 See id. 
developer's creating or improving public parks, plazas, or other amenities in exchange for their silence. ${ }^{338}$

Districts must decide to ban or accommodate these proprietors, as will local governments' land-use administrations. Districts should retain the right to their predominantly residential character. City planners need capacity to inventory home occupations and makerspaces within District boundaries, and consistent with ranges prescribed by regulation, to avoid overwhelming magnitudes of nonresidential uses. And where necessary, temporary moratoria may be appropriate pending closure of sufficient numbers of sharing producer sites. ${ }^{339}$ District Councils assessing these inventories, aided by city planning staff, are entitled to maintain balance among residential dwellers, conventional retailers, office providers and sharing producers, to retain a neighborhood "feel." employees should maintain the District's flow of information, using platforms like Nextdoor (private District social networks) ${ }^{341}$ or Neighborhood Link (a website platform) ${ }^{342}$ to maintain current information on District entitlement actions, building permit processing, and current or pending business licenses. Those municipal employees must acquire vital skills to explain the processes of sharing provider licensure and zoning entitlement to stakeholders and to moderate passionate conversations of disputants struggling over the introduction of unconventional "business models" into traditionally residential neighborhoods. ${ }^{343}$

In one regard, this quest for accommodation foments a struggle among generations; a struggle between established neighborhood dwellers and youthful sharing producers seeking to house their business operations in a historically "improper" zoning district. ${ }^{344}$

338 See id.

339 See supra Part IV.C.

340 See Miller, supra note 1, at 45 (arguing that a working committee to draft regulations should include representatives of the relative "interest groups" in the enclave).

341 See NeXTDOor, https://nextdoor.com/ (last visited Aug. 2, 2015).

342 See NeIGHBORHOOD LINK, http://www.neighborhoodlink.com/ (last visited Aug. 2, 2015).

Cf. Nolon, supra note 335, at 33 (describing trained local land-use leaders in the Hudson Valley facilitating "concept committees" involving stakeholders). See Miller, supra note 1, at 45 (asserting that working committees to establish regulations must incorporate cross-section of stakeholders).

${ }_{344}$ See Henry B.R. Beale, Home-Based Business and Government Regulation, SBA OFFICE OF ADVOCACY 72 (2004), https://www.sba.gov/sites/default/files/articles/Home\% 20Based\%20Business\%20and\%20Government\%20Regulation.pdf ("A home-based business is a commercial (or borderline industrial) land use in a residential neighborhood. In the past, the conflict between commercial land use and residential 
From another perspective, the general prohibition on entrepreneurial models in residential zoning districts undermines efforts to remake the social landscape of some urban communities, especially those mired in joblessness, crime and other indicia of disorder. ${ }^{345}$ Some invested in the sharing economy argue that today's good land use decisions demand subordinating individual inconvenience to the new business climate's benefit to the larger community-the so-called "greater good." 346 This argument is premised on the authentically evolved successes of walkability and sustainability dimensions-products of what Chuck Wolfe describes as "unpredictable, disjointed and overlapping," thrown-together land use patterns-in contrast to an artificially prescriptive or planned environment. ${ }^{347}$

Conflict will surely expand if regulations disadvantaging everyday citizens thwart the emerging, "wired-up city" of sharing producers. ${ }^{348}$ This does not suggest imminent Sharing Enterprise-coerced neighborhood occupancy. More likely, their producers will organize via social media to get their message to their supporters and to regulators in familiar and new forms of lobbying. ${ }^{349}$ More disturbing,

land use has been resolved by prohibiting home-based businesses.”).

345 See Stephen Clowney, Invisible Businessman: Undermining Black Enterprise with Land Use Rules, 2009 U. ILL. L. REv. 1061, 1070-73 (2009) (arguing that black-owned businesses, especially those operated by entrepreneurs, remain dormant in many urban centers due to burdensome municipal land-use practices).

${ }^{346}$ See, e.g., Roger Valdez, Community Based Land Use: From Individual Rights to Community Rights, SEATTLE's LAND UsE CODE (Aug. 8, 2012), https:// seattleslandusecode.wordpress.com/2012/08/08/community-based-land-use-fromindividual-rights-to-community-rights. See also Stahl, supra note 169, at 962 (positing that zoning decisions ought to incorporate some notion of the public good).

347 CHARLES R. WOLFE, Introduction, in URBANISM WITHOUT EFFORT (2013), available at http:/ / northwest.uli.org/wp-content/uploads/sites/39/2013/05/Wolfe_ introduction.pdf.

348 Scott Kirsner, Dispatch from the Disruption Zone, Bos. Globe InNOvation Econ. BLOG (Oct. 31, 2014), http://www.bostonglobe.com/business/2014/10/31/dispatchfrom-disruption-zone/j23NKZYrcBLdNm1DgOi96I/story.html (quoting Uber cofounder and Chief Executive Officer, Travis Kalanick).

${ }^{349}$ Cf. Juliet Schor, Debating the Sharing Economy, GREAT Transition InITIATIVE (Oct. 2014), http://greattransition.org/publication/debating-the-sharing-economy\# sthash. mhZQT9V9.dpuf (illustrating the Peers.org collaborative attempting to build a social movement of sharers); but see supra note 306 and accompanying text. Of course, success in lobbying for any short-term regulatory change will depend in significant part on whether the owners of numerous platforms for Sharing Enterprises support such efforts. I acknowledge that a great number of first-generation enterprises depend for survival on the backing of Silicon Valley's so-called "one percent," consisting primarily of venture capitalists (opposed to crowd-funding). See Irving Wladawsky-Berger, The Continuing Evolution of the On-Demand Economy, Inving WLADAWSKY-BERGER BLOG (July 21, 2015), http://blog.irvingwb.com/blog/2015/07/ the-continuing-evolution-of-the-on-demand-economy.html. 
some sharing producers will decide to operate undetectably whenever possible, preferring an underground approach to their operations ${ }^{350}$ that stymies efforts to achieve peaceful co-existence. Little is gained from substituting "what you don't know won't hurt you" for addressing resulting infrastructure burdens or for elevating the residential quality of the neighborhood. Since bending rules is a trait of human nature, ${ }^{351}$ sharing producers avoiding land use and licensing issues will prefer to work in the shadows, thereby seeking to minimize taxes, fees and other administratively imposed overhead items, avoiding entitlements, other regulatory requirements and licensure. ${ }^{352}$ Many consumers will cooperate in this endeavor, thereby lowering their costs of goods and services. ${ }^{353}$

Perhaps venture capitalists will render moot the challenges impeding Sharing Enterprise and neighbor détente. Invariably, capitalism engages persons to serially monetize sharing economy business models of the best output, extracting optimum value while putting proprietor-scale sharing producers out of business. ${ }^{354}$ But Jeremy Rifkin asserts American cities shortly will witness a surge in the zero marginal-cost society, ${ }^{355}$ under which a collaborative commons will be sustained by grassroots-owned "skinny platforms" resembling non-

350 See Schindler, supra note 10, at 32-34 (suggesting that some prosumers indeed may prefer the thrill of an illegal alternative).

351 See Robert A. Hinde, Bending the Rules: Morality in the Modern World FROM RELATIONSHIPS TO POLITICS AND WAR 197, 235-38 (2007).

352 See Schindler, supra note 10 at 20-21, 24, 32; Gene Johnson, Rethinking Legal Pot: Washington, Colorado Face Unexpected Problems, Portland Press Herald (Jan. 3, 2015), http:/ /www.pressherald.com/2015/01/03/rethinking-legal-pot-washington-

colorado-face-unexpected-problems/ (reporting that since recreational cannabis in Washington is heavily taxed unlike "medical marijuana," avoiding such tax (and pass through of that burden to consumers) has led to unlicensed sales and increasing numbers of registered medical users). See also supra text accompanying notes 151-57. Such defection explains why pool punishment ultimately may be inescapable, regardless of what land use "permitting scheme" is implemented in a community.

See Johnson, supra note 352 (reporting that consumers enroll as "patients" for medicinal cannabis products and buy from such clinics to avoid the higher price of recreational marijuana caused by vendors passing through the tax burden).

354 Cf. Rory Cellan-Hones, JustPark and the Sharing Economy, BBC FUTURE BLOG (Aug. 7, 2014), http://www.bbc.com/news/technology-28686606 (reporting Index Ventures' major investment in JustPark, a company that helps drivers look for a parking space). As a sharing economy niche emerges outside its cloak of illegality, established market participants will occupy and dominate the new market, since barriers to entry are not high and its technology drivers are "commodified" for the most part. Miller, supra note 1, at 17. Established market participants are equally as eager to participate in the sharing economy market space as their sharing economy counterparts are to share in the market space of the established market. See id. at 28.

355 See Jeremy Rifkin, The Zero Marginal Cost Society 16-25 (2014). 
profit cooperatives. ${ }^{356}$ Such an outcome insures that proprietors and prosumers will play pivotal roles in sharing production and consumption, forever changing the exclusive dwelling "feel" in residential zoning districts. If that society comes to fruition, sharing producers' dispersal within enclaves and ongoing formation of new technology-based businesses means Districts will best be served by transparency in producer operations and enlightened administrative regulation.

It seems likely that opposing factions in the sharing economy will achieve eventual détente through a series of phases transitioning through slow and deliberative dialog, perhaps not in precise linear order. In the first stage, everyday citizens will achieve an understanding that a community's economic and social competitiveness requires that the needs of the sharing producer accommodate those of residents. These citizens will recognize that the most agile communities attract the most entrepreneurially inclined persons with the potential to make the largest economic growth contributions to a District-and that such persons ought to be cautiously welcomed. A second phase may be a period of "coopetition," 357 where regulators seek to eliminate "win-lose outcomes" in monitoring and enforcing rules enabling sustainable community economic growth. In that period, master "plans" will yield to master strategies nimbly adapting to changes in the environment and economic conditions of a local community. ${ }^{358}$ For example, the District may assist the Sharing Enterprise in identifying public halls and meeting rooms, along with privately-owned public open spaces ${ }^{359}$

356 See id. at 131-35, 145, 164-65; Nathan Schneider, Owning is the New Sharing, SHAREABle Blog (Dec. 21, 2014), http://www.shareable.net/blog/owning-is-the-newsharing.

357 Instead of stakeholders assuming that their success must come at others' expense (a zero-sum game result), through co-opetition entities competing in the same industries act as if there is partial congruence of interests, such as by sharing information and expertise. Transparency about motivations, agendas and goals of the stakeholders develops as a result. See AdAm M. BRAndenburger \& BARRY J. Nalebuff, Co-OpETITION 5, 98-104 (1997).

358 TownSEND, supra note 47, at 305 (quoting email from Michael Joroff, Senior Lecturer, Massachusetts Institute of Technology Department of Urban Studies and Planning, to Anthony M. Townsend, author of the book (Jan. 28, 2012)); see also BARTON \& GRANT, supra note 244, at 49 (describing common-ground exploration for individual stockholders' gain, a "consultative" process leading to recognition of shared communities of interest).

359 See John King, S.F. Making Sure High-Rise Owners ID Hidden Public Spaces, SFCHRONICLE.COM BAY AREA \& STATE BLOG (Feb. 9, 2015, 11:50 AM), http://www.sfchronicle.com/bayarea/article/S-F-making-sure-high-rise-owners-IDhidden-6070126.php\#/0 (pointing out that citizens do not always know the location of accessible public spaces built by developers). 
within the District, in which work and customer meetings may occur. They may also assist in locating cheap storage and workshop space for sharing producer use. ${ }^{360}$ Concurrently, communities may embark upon mediated collective bargaining ${ }^{361}$ for adopting changes in regulations applicable to new sharing producer initiatives.

In a third evolutionary phase, community planners, aided by technology, will assume new roles as input-gatherers, interpreters and mediators. ${ }^{362}$ Neighborhood dashboards with real-time information on public display will visualize patterns of change, featuring how these patterns relate to forthcoming decisions concerning a proposed project's impact on traffic flow and pedestrian safety in its immediate vicinity, and prompt citizen input via social media on how to mitigate concerns. ${ }^{363}$ Planning "debates" will become fully deliberative because all stakeholders are better informed through inputs of those affected by the ultimate decisions reached. ${ }^{364}$ Crowdsourcing seems to be the future architecture of comprehensive civic participation in such forms of decision-making. Reaching greater sophistication in spatial planning as a quality of life issue, neighborhoods will become test-beds for sustainable-living "settlements." become crucial participants in the bottom-up approach to designing sustainable development that minimizes individual mechanical transportation and non-renewable resource waste by integrating harmonious living and working environments. ${ }^{366}$ Naturally, local governments will need to continue delivering critical public services with ample capacity and timeliness to all stakeholders, ${ }^{367}$ avoiding favoritism towards any faction of a neighborhood at the expense of another.

In the fourth phase of evolution, District Community Benefits Agreements become convenient mitigation vehicles attending land-

\footnotetext{
360 See BARTON \& GRANT supra note 244, at 115.

361 See Michael N. Widener, Bridging the Gulf, Using Mediated, Consensus-Based Regulation to Reconcile Competing Public Policy Agendas in Disaster Mitigation, 74 AlB. L. REV. 587, 613-27 (2011).

${ }^{362}$ Cf. id. at 617-19 (explaining how scientists act as interveners in the mediation process, both interpreting data and building trust among stakeholders).

363 TOwNSEND, supra note 47 , at 307.

364 Miller, supra note 1, at 24 (arguing that concepts of accommodation focusing "solely on regulators and the disruptive market participant" will fail; but an approach acknowledging the legitimate concerns of all stakeholders likely will yield results that are fair to all, creating lasting community benefits).

365 See BARTON \& GRANT, supra note 244, at 3-5.

366 See BARTOn \& GRANT, supra note 244, at 3-5.

367 See TOWNSEND, supra note 47 , at 309 .
} 
use modifications for specific developments ${ }^{368}$; under these agreements, Sharing Enterprises "pay it forward," contributing to neighborhood infrastructure like ICT upgrades or amenity upgrades within the District. ${ }^{369}$ These agreements need to be reached directly among persons most affected by the sharing producers' activities and those producers. These private stakeholders must collaboratively substitute their judgments for planning elites having little sense of the neighborhood's immediate requirements. As Community Benefits Agreements become progressively smaller in scope, public-private development partnerships may slowly replace elaborate regulatory codes and two-faction good neighbor contracts. ${ }^{370}$ Relatively benign but purposeful regulatory overlays will become the norm, and technology-capturing and analyzing Big Data-will make decisionmaking locally particularized and less "global" and, therefore, increasingly more flexible. ${ }^{371}$ With universal transparency, a Web-like operating system with open-access data affords property developers, citizens and planning bodies a collaborative ability to design new solutions in accommodating business models into residential areas. ${ }^{372}$ Providing essential services, at the election of the community, is left to social networks of more intimately-scaled neighborhoods. ${ }^{373}$ Smart

368 See Courtney Elizabeth Knapp \& Justin B. Hollander, Assessing the Potential for Integrating Community Benefits Agreements into Brownfield Redevelopment Projects, in RECLAIMING BRownFIELdS: A COMPARATIVE ANALYSIS OF AdAPTIVE REuSE OF Contaminated Properties 131 (Richard C. Hula, Laura A. Reese \& Cynthia JacksonElmoore eds., 2012).

369 Cf. Vicki Been, Community Benefits Agreements: A New Local Government Tool or another Variation on the Exactions Theme?, 77 U. CHI. L. REV. 5, 25-26 (2010) (criticizing the "diversion of benefits from the local government as a whole to the host neighborhood," by claiming it potentially creates greater inequality among the local government's neighborhoods). In the case of Sharing Enterprises, their owners might incorporate in such CBAs the trading of their services to neighborhoods, instead of paying for public amenities with cash, by creating local exchange and trading schemes. See BARTON \& GRANT, supra note 244, at 115. Ironically, sharing producers in the 3D printing "business" may assist Districts in physically-enhanced modeling of new urban planning initiatives. See T. Ghawana \& S. Zlatanova, 3D Printing for Urban Planning: A Physical Enhancement of Spatial Perspective, in URban And Regional Data Management 211 (C. Ellul, S. Zlatanova, M. Rumor \& R. Laurini eds., 2013), available at http:/ / www.isacsolutions.in/PDF/Modified3DPrintingandGISApplications.pdf.

370 See Miller, supra note 1, at 23 ("[I]f the city were to adopt a more flexible [regulatory] approach . . . the city and its citizens could also become partners in sharing the rewards of this risk tolerance.").

371 See id.; TownSEND, supra note 47, at 291.

372 See Miller, supra note 1, at 24 (discussing Sharing Enterprises' acceptance as viable, legal business ventures will find resolution only by engaging the full spectrum of stakeholders interested in the sharing economy and its manner of changing communities).

See TownSEND, supra note 47 , at 291. 
urban microprocessor-driven devices distributing aggregated data will not undermine sociability, but will reinforce it, allowing cities to thrive. $^{374}$

An obstacle to reaching this fourth phase will be wresting enough data from the sole ownership of companies bundling data as products and services to be sold to cities. ${ }^{375}$ Cities must resist companies' initiatives to lock them into contracts for proprietary services that effectively cede control of such data to private interests. ${ }^{376}$ Cities need to grow their own human infrastructure, enabling amateurs and small entrepreneurs to experiment through computational "laboratories" to work on future smart city technologies—a form of technology "literacy movement," building leadership networks of citizens. These networks will gather and share data, modeling, software and hardware designs, together with business models martialed for city joint problemsolving. ${ }^{377}$ Indeed, communities will need to join with the private sector to build local capacity to develop municipal technologies toward designing publicly-owned smart city solutions. Such development partnerships may even engage groups of citizens or neighborhoods as direct participants or investors. ${ }^{378}$

In the short haul, sharing entrepreneurs producing goods and services without a full time job or generating employment for others will grow in numbers. Communities must accommodate them not merely into downtowns and other mixed-use, densely urbanized centers, but throughout the general population. The permissions and sanctions local authorities grant and impose are optimized when a

374 See id.

375 See id. at 294.

376 See id.

377 See id. at 301; Nolon, supra note 335, at 46-47. One British author urges her national government to pilot a UK "sharing city," in which residents are urged to share as a daily routine and within which offices, residences and forms of transportation all become assets for joint usage. See Debbie Wosskow, Unlocking the Sharing Economy: An Independent Review, U.K. Dep't of Bus. Innovation \& Skills Ch. 5 (Nov. 2014), https://www.gov.uk/government/uploads/system/uploads/attachment_data/file/3 78291/bis-14-1227-unlocking-the-sharing-economy-an-independent-review.pdf.

378 See Max Taves, Detroit Tiger Stadium Redevelopment Project Turns to "Crowdfunding," WALL ST. J., Feb. 11, 2015, at C6, available at http://www.wsj.com/articles/detroitstiger-stadium-redevelopment-project-turns-to-crowdfunding-

1423610035?KEYWORDS=MAX+TAVES (using an online crowdfunding platform selling preferred stock to local residents (and "unaccredited investors") in order to finance part of the equity for a mixed-use project). See also Andrew Blackman, Crowdfunding Comes to Real Estate, WALL ST. J., Apr. 14, 2014, at R3, available at http:/ / online.wsj.com/articles/SB10001424052702303725404579459271078527790 (reporting new websites that allow individual investments in self-storage facilities and hotels). 
District's residents, dwellers, producers, and prosumers collaboratively reinforce rules and join with public administrators in that governance process. Redress against defectors from new operating norms must include forms of peer- and pool sanctioning by sharing producers. ${ }^{379}$ This form of regulation affords a community its moment to sustain an indigenous, organic, street-level culture central to all its citizens' lives. ${ }^{380}$

\section{APPENDIX: LEXICON}

Big Data: The manipulation of large data sets generated by persons and maintained by computers and by the Internet of Things to drive decision-making.

Citizens: Persons living in the neighborhood who are affected by, whether or not customers and clients of, sharing producers.

Community Benefits Agreements: Agreements between the sharing entrepreneur class and the residential neighborhoods that establish ground rules for sharing producers to operate businesses in residential areas and the quid pro quo payable for that privilege.

Districts, or Enclaves: Areas of a community aided by large datasets that mine resident information and statistics in useful chunks and matrices to reach land use regulation decisions affecting those living and working within the area. A "district" or an "enclave" as easily could be called a neighborhood, a village or a hamlet; it means a subset of the overall community small enough to lend itself to greater local inputs or, in the rare instance, to control over entitlements decisions.

Euclidean Zoning: A zoning scheme that rigidly defines permitted uses in each of several zoning districts, initially created to segregate residential from non-residential uses.

ICT: Collectively, information and communications technologies, all depending on broadband or telecommunications servers.

Micro-Jobbers: A subset of sharing entrepreneurs akin to the medieval "journeyman" that offers their services to businesses involving leveraging of technology, including software coding, but also "making" with the use of technology, such as via 3D printing and similar software-driven replication, on a daily or hourly basis without any form of permanent alliance with any particular business.

Millennials: Younger Americans born roughly between 1983 and

379 Cf. Cohen \& Sundararajan, supra note 81, at 129 (underscoring the value of including sharing producer platforms "as enforcers of the self-regulatory solution").

380 See JACOBS, supra note 26, at 117-25, 133-40; see also FLORIDA, supra note 326, at 148-54, 281-82, 329-31. 
2003

Peer and Pool Punishment: When certain people start reaping benefits of a common good without paying a share of the efforts of the group, these exploiting individuals are known as "free-riders." Freeriding behavior is frequently sanctioned in society by punishment. Delivery of punishment by individuals (peer punishment) is itself susceptible to free-riding; that is, other individuals benefit from the "punisher's" efforts without participating in the cost of punishment delivery. Those non-contributors to the punishment's delivery are known as "second-order free riders." Pool punishment occurs (in contrast to peer punishment) when individuals contribute to a "punishment pool;" then, the punishment is delivered to exploiters (free-riders) by an actor funded by its contributors. This cost-sharing occurs even when exploiters do not exist-therefore, even in the absence of punishment. ${ }^{381}$ The mere presence of the pool-punishment actor is a signal that induces cooperation (and thereby likely reduces free-riding). So, a zoning enforcement agency in a community, funded by taxpayers to enforce the zoning ordinance against defectors from its rules, is a type of a punishment pool.

Prosumer. A consumer who becomes a "product and brand advocate." Rather than simply consuming products, prosumers are the "voices" of those products, significantly impacting the success or failure of companies, products, and brands, particularly through their involvement on the social web. Members of the social web-bloggers, micro-bloggers, forum posters and social networking participants who spread messages, influence people around the world and drive demand.

Sharing Enterprises: The niche businesses established by sharing producers.

Sharing Producers: The entrepreneurial class that, through niche marketing using Web 2.0 technologies and social networking platforms, sells goods and services without a visible store front or office location; micro-jobbers are one type of such entrepreneurs, except their services alone are for sale, frequently on a single engagement ("one-off") basis. Some sharing producers are creating, meaning they produce new goods from their assets; others are extracting, meaning they derive value from their existing assets (such as from their vehicles, as drivers, or from their real property, as short-term innkeepers). Some are independent contractors; others are so-called "dependent

381 See Todd Bodnar \& Marcel Salathé, Governing the Global Commons with Local Institutions, PLOS (Apr. 3, 2012), http://journals.plos.org/plosone/article? $\mathrm{id}=10.1371 /$ journal.pone.0034051. 
contractors," such as persons who "drive for" Lyft, for instance, because these producers do not operate their own Web-driven business model. $^{382}$

Zoning Adjustment: Use permits (sometimes known as "special exceptions") and area/dimensional variances, as well as zoning ordinances interpretations, any of which processes may result in "permission" to establish certain types of uses including Sharing Enterprises.

382 See Christopher Mims, How Everyone Gets the 'Sharing' Economy Wrong, WALL ST. J. TECH (May 24, 2015), http://www.wsj.com/articles/how-everyone-gets-the-sharingeconomy-wrong-1432495921. 